Ph.D. Thesis

\title{
CAROTENOIDS ASSIST IN ASSEMBLY AND FUNCTIONS OF PHOTOSYNTHETIC COMPLEXES IN CYANOBACTERIA
}

Özge Sözer

Supervisors: Dr. Zoltán Gombos \& Dr. Mihály Kis

\author{
University of Szeged \\ Biological Research Centre \\ Hungarian Academy of Sciences Szeged
}

Szeged

2011 


\section{TABLE OF CONTENTS}

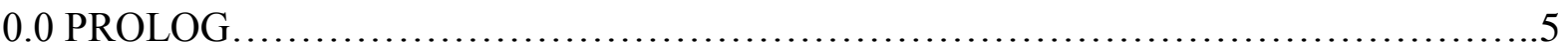

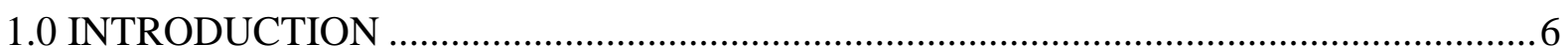

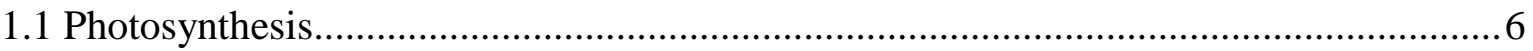

1.1.1 Light Harvesting Antenna System....................................................................

1.1.2 Major photosynthetic complexes in thylakoid membrane........................................8

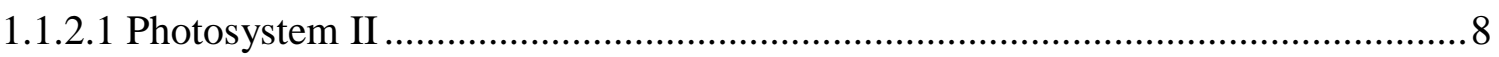

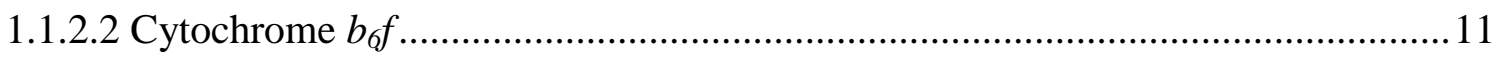

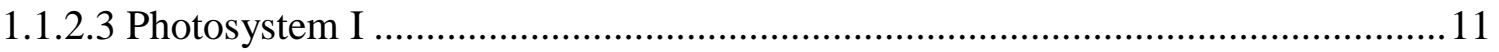

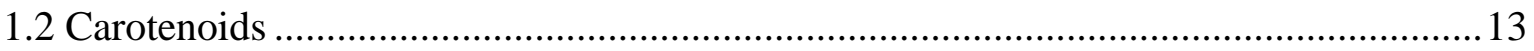

1.2.1 Chemical structure and some physiological properties of carotenoids.............13

1.2.2 Functional roles of carotenoids in photosynthesis................................................. 15

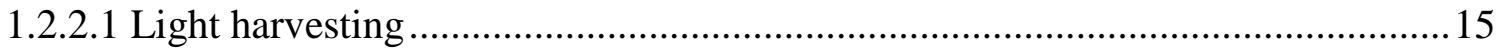

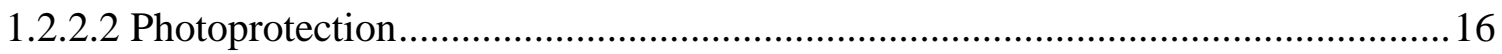

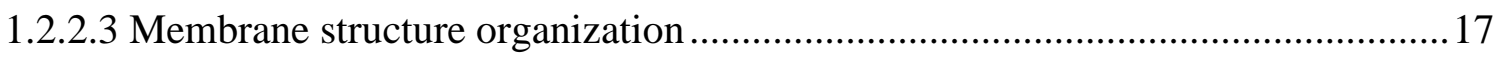

1.3 Model Organism: Cyanobacterium Synechocystis sp. PCC 6803 …………………......18

1.4 Biosynthetic pathway of carotenoids in Synechocystis................................................. 18

1.5 Localization of carotenoids in photosynthetic complexes ...........................................2

1.5.1 Localization of $\beta$-carotene molecules in photosystem II........................................2.

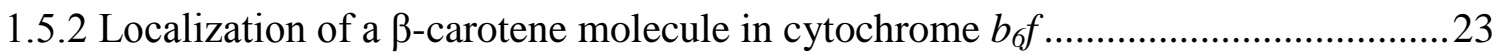

1.5.3 Localization of $\beta$-carotene molecules in photosystem I .........................................23

1.6 Phosphatidylglycerol in photosynthesis .....................................................................24

1.7 Earlier studies on carotenid mutants in cyanobacteria...............................................25

2.0 AIMS

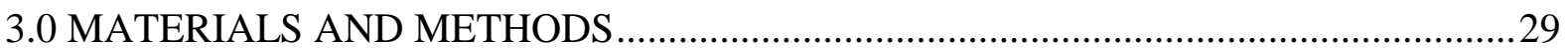

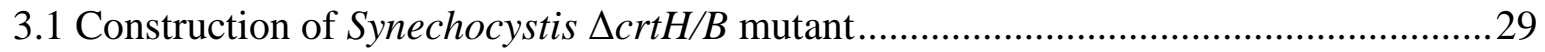

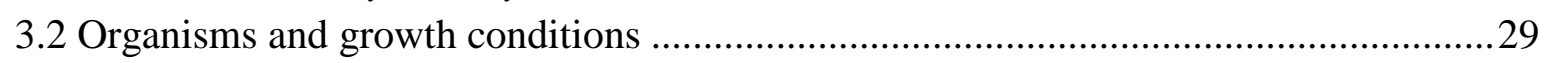

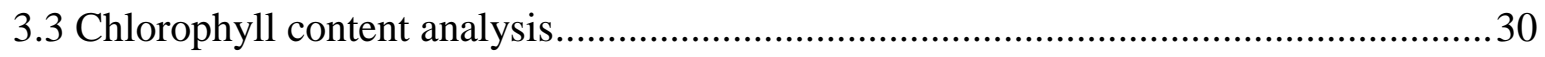

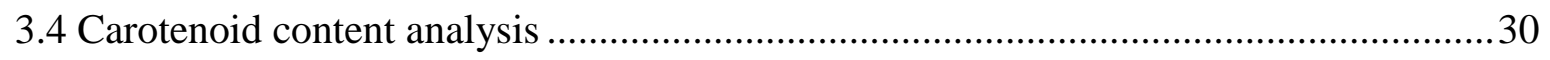

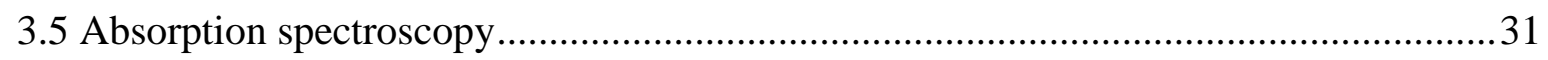

3.6 Low-temperature (77 K) fluorescence spectroscopy .................................................. 31

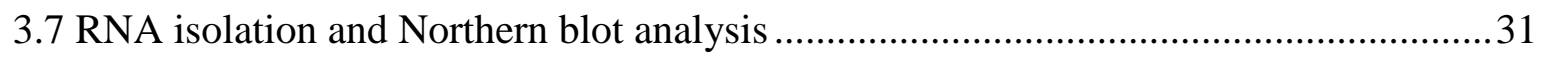

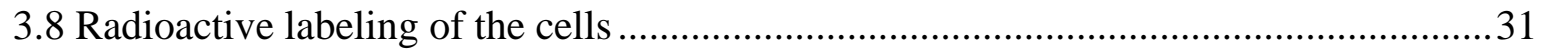

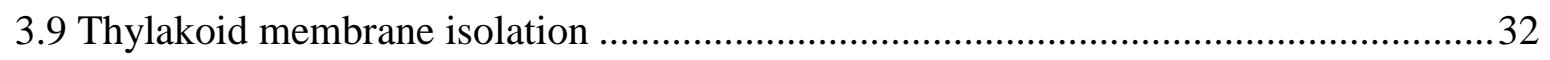

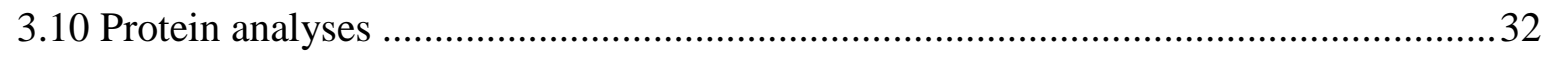

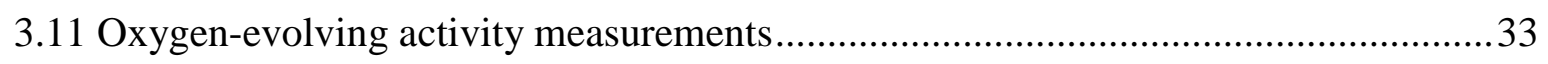


3.12 Chl $a$ fluorescence efficiency (Fv/Fm) and the maximum changes in P700 signal (Pm-

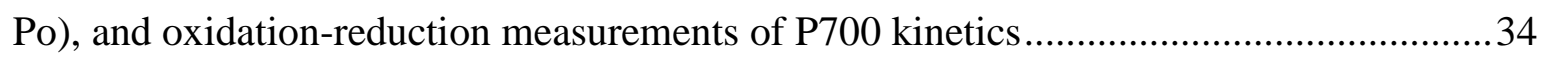

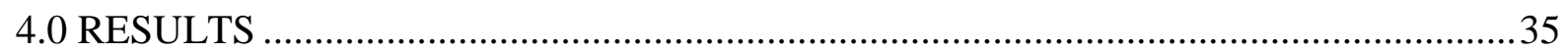

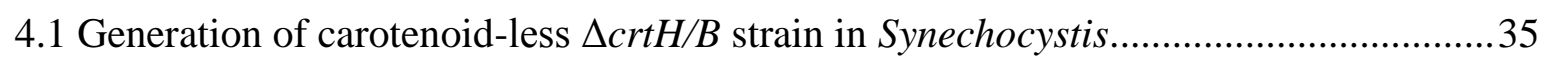

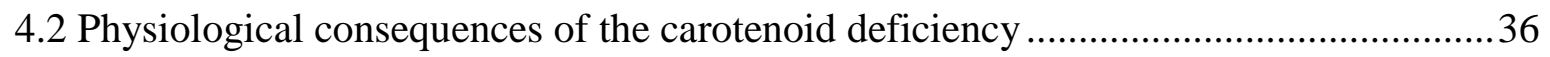

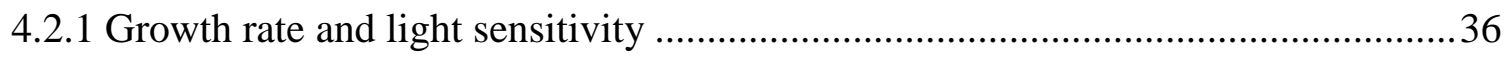

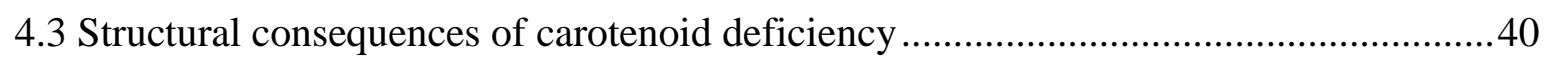

4.3.1 Level of the large protein subunits of photosynthetic complexes .......................... 40

4.3.2 Assembly of the photosynthetic complexes and their large protein subunits..........41

4.3.3 Stabilization of the small protein subunits binding to the large protein subunits in

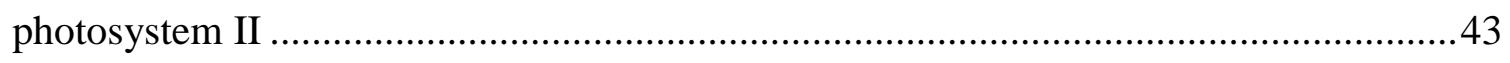

4.3.4 Assembly of the functioning photosystem II core complex ..................................45

4.3.5 Level of genes encoding PSII large protein subunits ......................................... 47

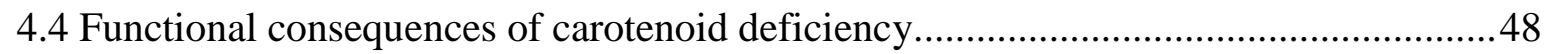

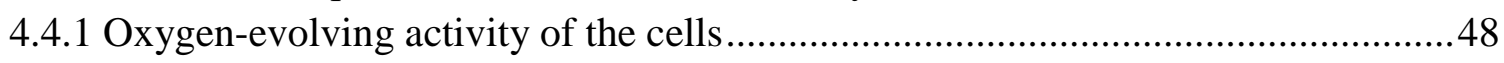

4.4.2 Maximal photosystem II efficiency in dark adapted state (Fv/Fm)........................ 48

4.4.3 Maximal redox changes in P700 signal in dark adapted state (Pm-Po) ..................49

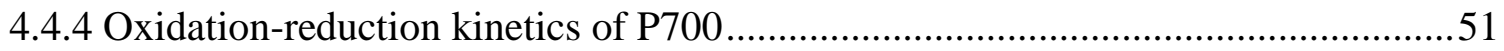

4.5 Phosphatidylglycerol (PG) depletion induces an increase in myxoxanthophyll and echinenone biosynthetic activities in Synechocystis PCC 6803 cells ...............................52

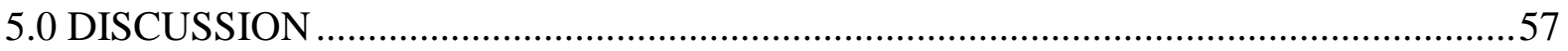

5.1 Structural and functional consequences of the carotenoid deficiency in the Synechocystis

5.2 Phosphatidylglycerol (PG) depletion induces an increase in myxoxanthophyll and echinenone biosynthetic activities in Synechocystis PCC 6803 cells...............................65

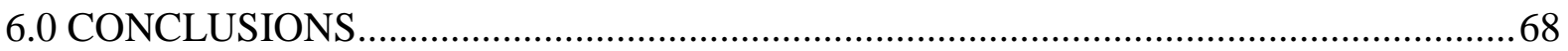

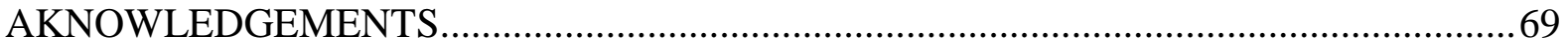

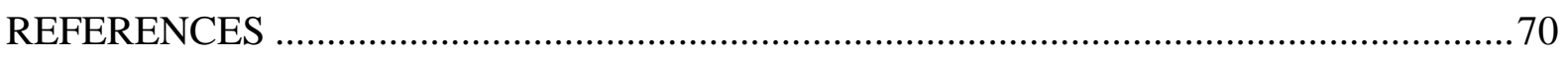

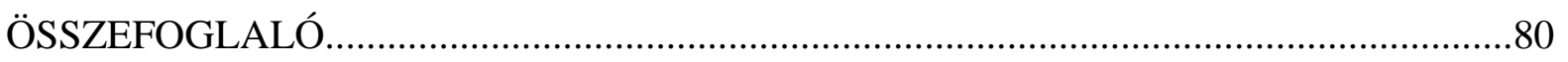

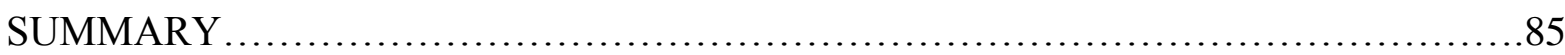

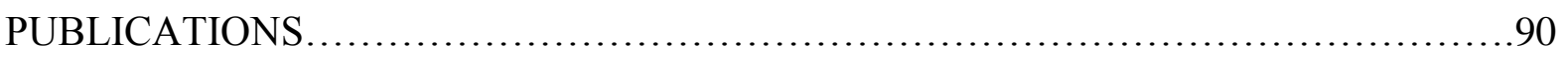




\section{ABREVIATIONS}

$\mathrm{Abs}_{\max }$

Chl

CP43 and CP47

Cyt $b_{6} f$

D1 and D2

DCMU

Fo

Fm

Fv

iD1

HPLC

LAHG

NPQ

OD

OEC

PBS

pD1

PG

$p g s A$

$\mathrm{Pm}$

Po

PsaA and PsaB

P680

P700

$\mathrm{RC} 47$

$\mathrm{RCC}(1)$ and $\mathrm{RCC}(2)$

PSI(1) and PSI(3)
Absorbance maximum

Chlorophyll

Photosystem II antenna chlorophyll-protein subunits

Cytochrome $b_{6} f$ complex

Photosystem II core complex protein subunits

3-(3,4-dichlorophenyl)-1,1-dimethylurea

Fluorescence yield of open PSII RCs in dark-adapted state

Maximum fluorescence yield of closed PSII RCs in darkadapted state

Maximum fluorescence change in dark-adapted state (Fm-Fo)

Intermediate form of D1 protein subunit after removal of part of the C-terminal extension

High performance liquid chromatography

Light-activated heterotrophic growth

Non-photochemical quenching

Optical density

Oxygen-evolving complex

Phycobilisome

Precursor form of D1 protein subunit with complete C-terminal extension

Phosphatidylglycerol

The mutant deficient in phosphatidylglycerol (PG) synthesis

Maximum P700 signal in dark-adapted state

Minimum P700 signal in dark-adapted state

Photosystem I core complex protein subunits

Primary electron donor of PSII reaction center

Primary electron donor of PSI reaction center

Intermediate PSII complex lacking inner antennae

CP43 protein subunit

Monomeric and dimeric PSII complexes, respectively

Monomeric and trimeric PSI complexes, respectively 
$\mathrm{RC}$

$\mathrm{RCa}$

ROS

2D-BN/SDS-PAGE

$\Delta c r t H$

$\Delta c r t H / B$
Reaction center

Intermediate PSII complex containing D1 (or iD1), D2 and

Cyt $b-559$ but lacking CP47 and CP43

Reactive oxygen species

Two-dimensional blue native/sodium dodecyl sulfate

polyacrylamide gel electrophoresis

The mutant deficient in cis- to trans- carotene isomerase encoded by $\mathrm{crtH}$ gene in Synechocystis

The mutant deficient in the phytoene synthase encoded by $\operatorname{crt} B$ gene 


\subsection{PROLOG}

Cyanobacteria are a fascinating and versatile group of bacteria of immense biological importance. In earth history cyanobacteria as nitrogen and carbon-fixing organisms have a special position and they play a significant role in Earth's nitrogen and carbon cycles. Cyanobacteria are able to perform nitrogen and carbon fixation, which are often competing metabolic processes in the same cell. Moreover, their ancestors are the first oxygen-evolving organisms, which were responsible for the oxygen in the atmosphere due to their photosynthetic activity, which was invented 2.8 billion years ago. Cyanobacteria even nowadays contribute up to $30 \%$ of the yearly oxygen production on Earth.

Carotenoids are ubiquitous compounds playing a role in a range of special processes. Thus, they are regarded as essential compounds for life mainly due to their various roles in photosynthesis. During the last couple of year interest in these pigments get into the focus of plant biology. Recently, various genes involved in carotenoid biosynthesis of several bacterial organisms have been indentified, which offers new opportunities for the genetic engineering of carotenoid synthesis in vivo.

Complete genome sequences and the transformability of several cyanobacterial strains allow us to generate various mutants and study the importance of carotenoids in photosynthetic processes. We aimed to generate a carotenoid deficient mutant in order to understand the structural and functional roles of carotenoids in photosynthesis. 


\subsection{INTRODUCTION}

\subsection{Photosynthesis}

Photosynthesis is a process by which the energy of sunlight is converted into chemical energy in higher plants, algae and cyanobacteria. Photosystem II (PSII), photosystem I (PSI), cytochrome $b_{6} f$, (Cyt $\left.b_{6} f\right)$, and ATP-synthase are the four major protein complexes embedded in the thylakoid membranes. Both PSI and PSII reaction centers (RCs), which carry out lightdriven electron transfer, are surrounded by light-harvesting antenna systems, which consist of protein-pigment complexes. Both photosystems are coupled functionally by a plastoquinone pool, the Cyt $b_{6} f$ complex, and plastocyanin or cytochrome $c_{6}$ (Fig. 1).

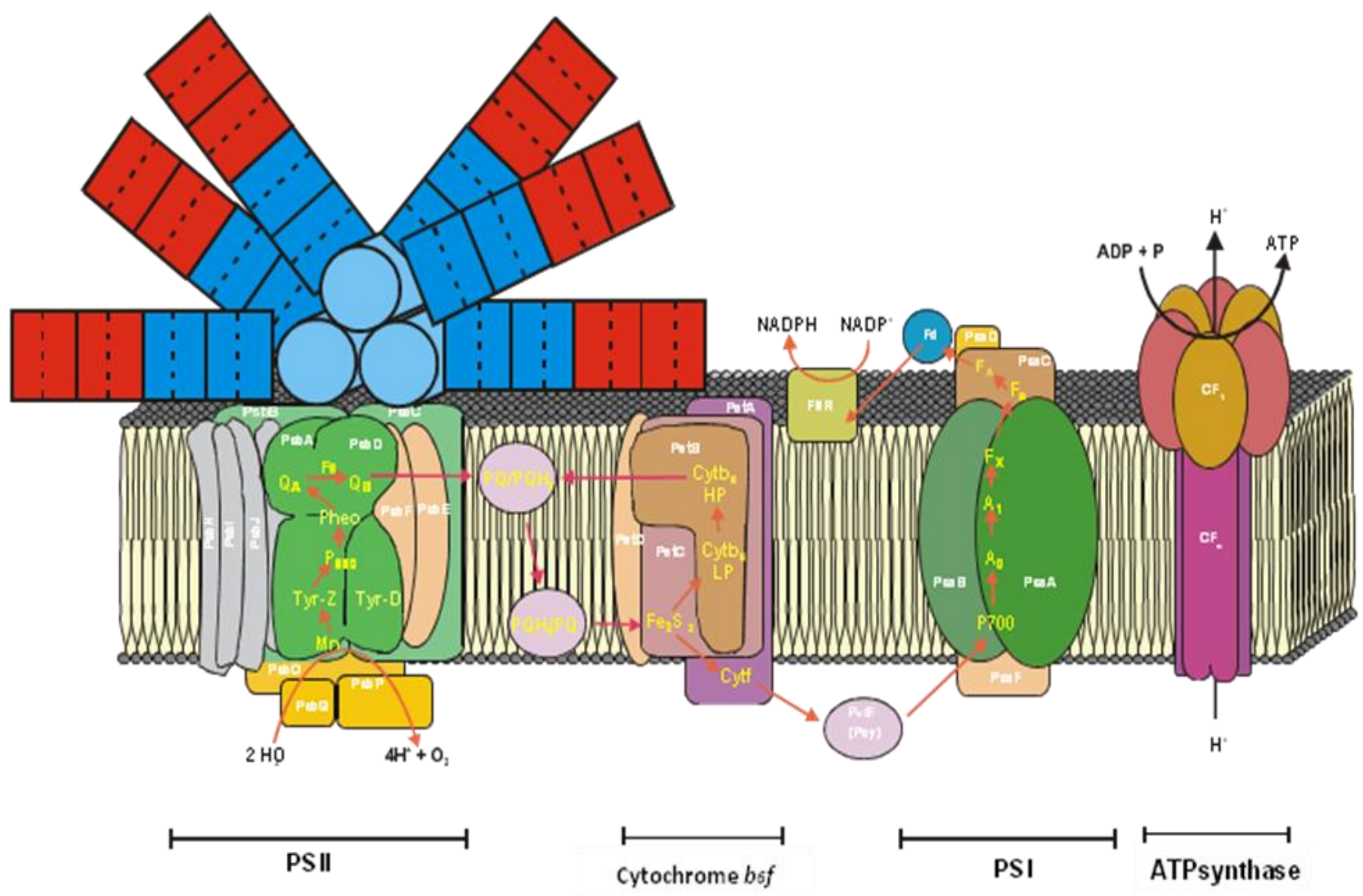

Figure 1: Major photosynthetic complexes of thylakoid membrane of cyanobacteria Major complexes (Photosystem II, cytochrome $b_{6} f$, photosystem I and ATPsynthase) and light driven electron transfer chain across the membrane. The figure was adapted from Dr. Donald A. Bryant (1994) and modified by Dr. László Kovács. 


\subsubsection{Light Harvesting Antenna System}

Photosynthetic organisms have additional peripheral light harvesting antenna complexes containing different pigments, which are specifically associated with proteins in a unique structure of photosynthetic apparatus in order to overcome the light limited conditions by extending the spectral range of absorbance. The large protein antenna complexes of higher plants contain chlorophyll $a(\mathrm{Chl} a)$, chlorophyll $b$ and xanthophyll pigments. Some marine organisms, such as diatoms and brown algae utilize xanthophylls, $\mathrm{Chl} a$, and chlorophyll $c$ within a single light harvesting antenna complex. Red algae and cyanobacteria have phycobilisomes. Although the various peripheral light-harvesting antennas differ significantly among the photosynthetic organisms, their common functions are to absorb light energy and to control dissipation of excess excitation energy under light stress, and to regulate energy flow between the two photosystems.

In cyanobacteria, there are specific light harvesting antenna complexes, phycobilisomes (PBSs), which consist of phycobiliproteins (Fig. 1). In the cyanobacterium Synechocystis sp. PCC 6803 (hereafter Synechocystis) there are two blue-pigmented phycobiliproteins: phycocyanin $\left(\mathrm{Abs}_{\max } 620 \mathrm{~nm}\right)$ and allophycocyanin $\left(\mathrm{Abs}_{\max } 650 \mathrm{~nm}\right)$. Some cyanobacteria also have phycoerythrin, a red-pigmented phycobiliprotein $\left(\mathrm{Abs}_{\max } 560\right.$ $\mathrm{nm})$. The PBSs contain core and rod substructures. Phycoerythrin and phycocyanin form the rods, which efficiently absorb and transfer excitation energy to the PBS core, which consist predominantly of allophycocyanin (Liu et al. 2005). The PBS core also contains terminal emitters $\left(\mathrm{Abs}_{\max } 683 \mathrm{~nm}\right)$, which tunnel light energy from the PBSs to the RCs. The exact interaction between the PBS and the photosystems is still under debate. It is known that a PBS can also be decoupled from the Photosystems, leading to long-lived excitation (Bittersmann and Vermaas 1991). PBS excitation energy distribution between the two photosystems is regulated, in order to optimize photosynthetic performance (Mullineaux 2008). PBSs are also subject to carotene-triggered dissipation of absorbed energy as heat. The phenomenon is known as non-photochemical quenching (NPQ) in cyanobacteria (Rakhimberdieva et al. 2010) 


\subsubsection{Major photosynthetic complexes in thylakoid membrane}

\subsubsection{Photosystem II}

The PSII complex has been conserved among cyanobacteria, algae and higher plants. The X-ray crystallographic structure of the monomeric PSII complex from Thermosynechococcus elongatus (T. elongatus) consists of 17 intrinsic and 3 extrinsic protein subunits, $35 \mathrm{Chl} a, 11 \beta$-carotene, 2 haem, and one non-haem iron molecules, two calcium ions, at least 25 integral lipids, 1-2 chloride ion(s), 3 plastoquinones and $\mathrm{CaMn}_{4}$ cluster (Ferreira et al. 2004, Loll et al. 2005, Guskov et al. 2009, Guskov et al. 2010).

The membrane intrinsic part of monomeric PSII consists of the core complex protein subunits D1 and D2, each containing 5 transmembrane $\alpha$-helices which bind Chl, pheophytin and plastoquinone co-factors (Rappaport and Diner 2008). In addition, there are intrinsic antenna protein subunits CP47 and CP43, each containing 6 transmembrane $\alpha$-helices, which bind $26 \mathrm{Chl} a$ and $9 \beta$-carotene molecules (Loll et al. 2005). These four large protein subunits are surrounded by 13 low-mass small protein subunits on the periphery of the PSII. Cytochrome b-559 (Cyt b-559) consists of two transmembrane $\alpha$-helices; PsbE and PsbF represents two of those small protein subunits. Cyt b-559 is able to accumulate in the membrane in the absence of D1 and D2 (Komenda et al. 2004). It seems to act as a nucleation factor to initiate PSII assembly: the formation of the first Cyt b-559-D2 subcomplex (Fig. 2) (Komenda et al. 2004, Komenda et al. 2008). After the integration of D1 and PsbI, (Dobakova et al. 2007), an intermediate PSII complex, RCa is formed (Fig. 2) (Komenda et al. 2008). In the absence of CP47, CP43 is unable to attach stably to the subcomplex (Komenda et al. 2008), although in the absence of CP43, CP47 is able to attach to the subcomplex and forms the next intermediate PSII complex, RC47 (Fig 2) (Komenda et al. 2004). RC47 is unable to oxidize water but is still able to drive oxidation of redox-active tyrosine, TyrZ, in D1. The subsequent attachment of CP43 allows the formation of monomeric PSII complex (RCC(1)) (Fig. 2), which is the starting point for the light-driven assembly of the $\mathrm{CaMn}_{4}$ cluster together with the attachment of the extrinsic protein subunits PsbO, PsbV and PsbU. They are located at the lumenal side of the core complex assembly and contribute to the stability of the $\mathrm{CaMn}_{4}$ cluster (Fig. 2) (Roose et al. 2007, Enami et al. 2008). Finally two monomeric PSII complexes form a dimeric PSII complex (RCC(2)) (Fig. 2). Both monomeric and dimeric PSII complexes can be formed in whole cells and isolated 
thylakoid membranes of Synechocystis and T. elongatus with dimeric form being the more active form (Nowaczyk et al. 2006).

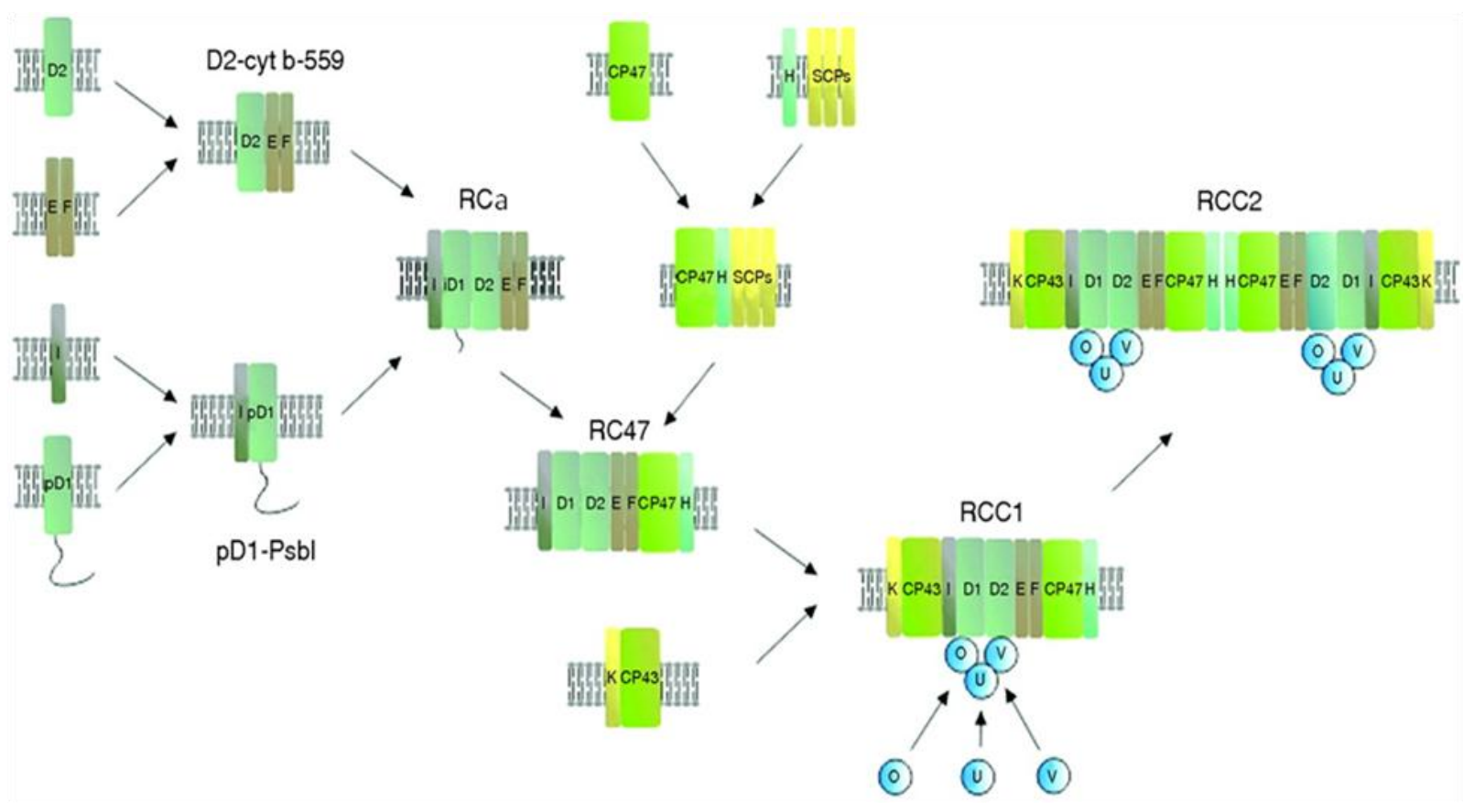

Figure 2: Assembly of PSII complex in Synechocystis.

The small protein subunits PsbE, PsbF, PsbH, PsbI and PsbK and the extrinsic protein subunits PsbO, PsbU and PsbV are designated by the upper case letter. Cytochrome b-559 (cyt b-559) is composed of a heterodimer of PsbE and PsbF. Types of PSII complexes: RCa, intermediate PSII complex containing either mature D1, intermediate D1 (iD1), or precursor D1 (pD1) but lacking CP43 and CP47; RC47, intermediate PSII complex lacking CP43; RCC(1), monomeric PSII complex; RCC(2), dimeric PSII complex. For clarity, assembly of the cofactors and many of the small protein subunits is not included. The figure was adapted from Nixon et al. (2010).

During biogenesis of PSII, D1, which is synthesized in most organisms as a precursor protein, pD1, with a C-terminal extension (16 amino acid extension), must be cleaved to allow the assembly of a functional $\mathrm{CaMn}_{4}$ cluster. During $\mathrm{C}$-terminal extension processing, the intermediate of D1, designated iD1 can be found (8 amino acid extension), (Komenda et al. 2007). The iD1 is found mainly in PSII complexes in vivo (Komenda et al. 2004). Cterminal extension is not required for assembly of the oxygen-evolving complex (OEC) of PSII (Satoh and Yamamoto 2007). However, mutants either lacking the extension or containing modified C-terminal extension are in general much more susceptible to photoinhibition (Ivleva et al. 2000, Kuvikova et al. 2005). 


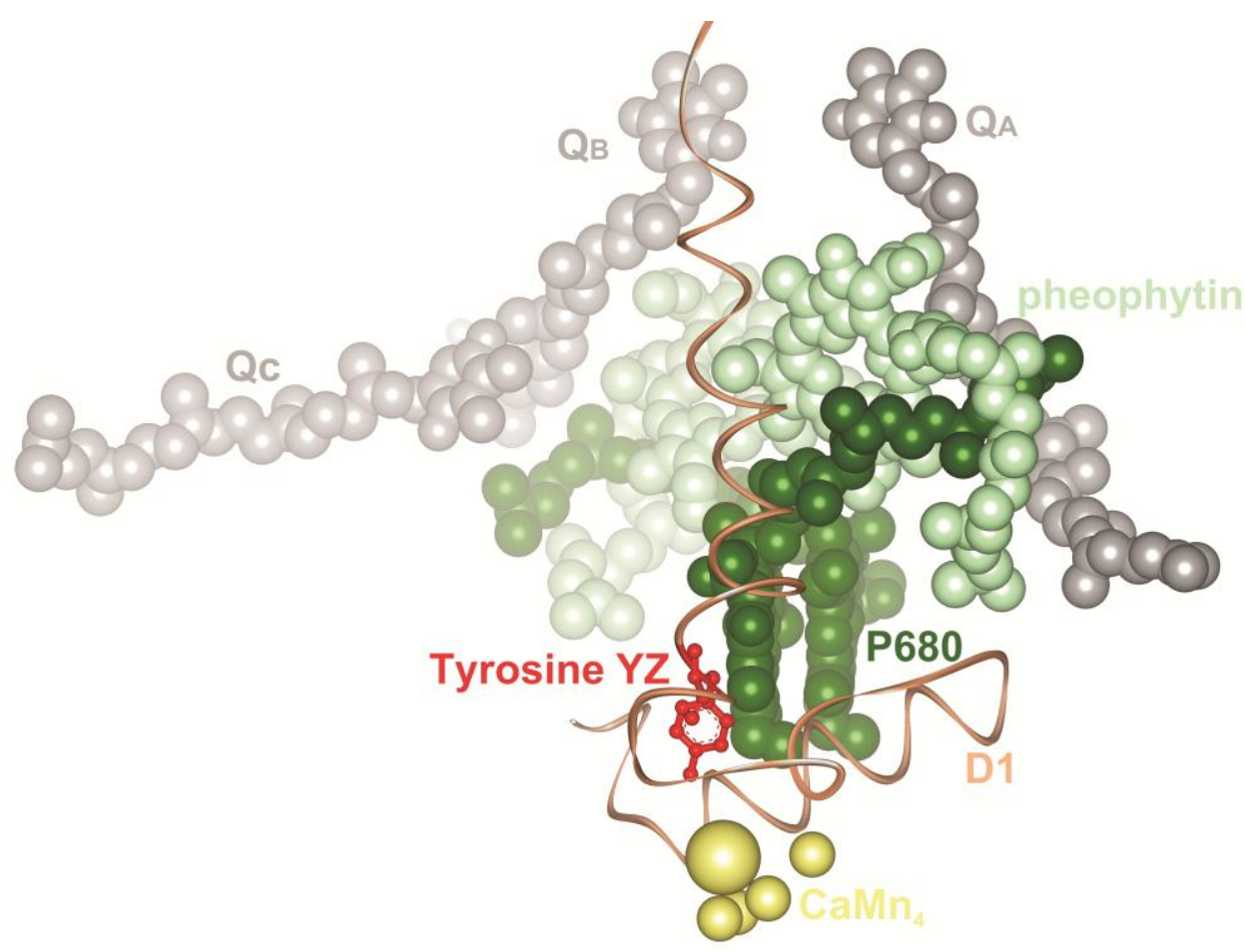

Figure 3: Electron transport chain in PSII RC

Major participants: P680, (dark green); pheophytin, (light green); $\mathrm{Q}_{\mathrm{A}}, \mathrm{Q}_{\mathrm{B}}$, and $\mathrm{Q}_{\mathrm{C}}$ (grey); $\mathrm{CaMn}_{4}$ cluster (yellow) and tyrosine $\mathrm{Z}$ (red). The figure was created by the software Discovery Studio Visualizer (DSV) (http://accelrys.com/products/discoverystudio/visualization) and the PDB file 3BZ1 (Guskov et al. 2009).

Light energy captured by the light harvesting antenna complexes is transferred to PSII RC. In the RC, light-induced charge separation takes place leading to the oxidation of P680 $\left(\mathrm{P} 680^{+}\right)$, which is a heterodimeric $\mathrm{Chl} a$ pair. The electron released from excited P680 (P680*) travels along the redox-active cofactors of the electron transfer chain. Pheophytin is the first electron acceptor. Then two plastoquinone molecules $\mathrm{Q}_{A}$ and $\mathrm{Q}_{B}$ receive electrons from pheophytin. The tightly bound $\mathrm{Q}_{\mathrm{A}}$ acts as electron transmitter and the mobile $\mathrm{Q}_{\mathrm{B}}$ is the substrate of the quinone reductase part of PSII complex (Fig. 3). An additional plastoquinone molecule $\left(\mathrm{Q}_{\mathrm{C}}\right)$ with unresolved function has been located next to the $\mathrm{Q}_{\mathrm{B}}$ binding site. After two charge separation events, the doubly reduced $\mathrm{Q}_{B}\left(\mathrm{Q}_{\mathrm{B}}{ }^{2-}\right)$ binds two protons from the stromal side of the membrane yielding a fully reduced plastohydroquinone, $\mathrm{PQH}_{2}$.

$\mathrm{P} 680^{+}$has an exceptionally strong oxidizing power and is able to abstract electrons via redox active tyrosine $\mathrm{Z}$ from the OEC, a heteronuclear $\mathrm{CaMn}_{4}$ cluster located at the lumenal side of PSII (Fig. 3). After the accumulation of four positive charges, water is oxidized to molecular oxygen. The oxidation of two water molecules in PSII results in the 
release of four protons in the lumen. This contributes to the formation of the electrochemical gradient that drives ATP synthesis.

\subsubsection{Cytochrome $b_{\sigma} f$}

The Cyt $b_{6} f$ complex, which is another large membrane-bound protein complex, lies between PSII and PSI complexes in the thylakoid membrane. In general the native dimeric form consist of eight protein subunits and several cofactors legated to the proteins (Kurisu et al. 2003). Four of these are considered the large protein subunits and include Cyt $f$, the Rieske iron-sulfur protein, Cyt $b_{6}$, and subunit IV.

Electrons are transferred through mobile plastoquinone $\left(\mathrm{PQH}_{2}\right)$ molecules from PSII to the Cyt $b_{6} f$ complex. Cyt $b_{6} f$ donates the electrons to one of the lumenal electron carrier proteins, plastocyanin, (or in some cases to Cyt $c_{6}$ ), which carries the electron, to PSI. Further, the reoxidation of two $\mathrm{PQH}_{2}$ by Cyt $b_{6} f$ also results in the release of an additional four protons in the lumen, thereby contributing to the formation of the electrochemical gradient that drives ATP synthesis.

\subsubsection{Photosystem I}

X-ray crystal structure of the monomeric PSI complex from T. elongatus exhibits 12 protein subunits which are bound to 127 cofactors performing light capturing and electron transfer (Jordan et al. 2001, Fromme et al. 2001, Grotjohann and Fromme 2005, ElMohsnawy et al. 2010). These cofactors include $96 \mathrm{Chl} a$ and 22 carotenoids, two phylloquinones, three iron-sulfur cluster and four lipid molecules. The central part of the core complex is formed by the heterodimer of the two large protein subunits PsaA and PsaB, comprising 22 transmembrane helices, located in the center of the monomeric PSI complex. They coordinate most of the $\mathrm{Chl} a$, carotenoids and the redox cofactors of electron transport (Amunts and Nelson 2009). PSI exists in vivo in monomeric and trimeric forms. The trimeric PSI is the most abundant in the thylakoid membrane of $T$. elongatus and the formation of trimeric form is essential for the growth of the cells at low light intensity (Grotjohann and Fromme 2005). Trimeric PSI form also plays an important role in the assembly and structural integrity of PSI (Grotjohann and Fromme 2005). Interaction of antenna Chl $a$ of the monomeric forms within the trimeric form leads to a larger amount of long-wavelength $\mathrm{Chl} a$, resulting in a higher photochemical activity of the trimeric form under red or far-red illumination. The dynamic equilibrium between monomeric and trimeric 
forms in the thylakoid membrane may indicate a transient monomeric population in the course of biogenesis and could also be the basis for short-term adaptation of the cell to changing environmental conditions (El-Mohsnawy et al. 2010).

PSI catalyzes the light driven electron transfer from plastocyanin, which is located on the lumenal side of the thylakoid membrane, to ferredoxin, which is located on the stromal side of the membrane. In some cyanobacteria and green algae, Cyt $c_{6}$ can replace plastocyanin as an electron donor to PSI. Excitation energy captured by antenna pigments is funneled to P700, a heterodimer of Chl $a$ pair in PSI RC where the charge separation takes place. The electron is transferred from P700 stepwise to A and $\mathrm{A}_{0}$ (Chl $a$ molecules), $\mathrm{A}_{1}$ (a phylloquinone molecule) and from there subsequently to the iron-sulfur clusters, FX, FA and FB. The latter mediates electron transfer to ferredoxin, which act as soluble electron carrier. Ferredoxin transfers the electron to the ferredoxin $\mathrm{NADP}^{+}$-reductase enzyme (FNR), which then finally reduces $\mathrm{NADP}^{+}$to NADPH (Fig. 4). To complete the cycle, $\mathrm{P} 700^{+}$is re-reduced.
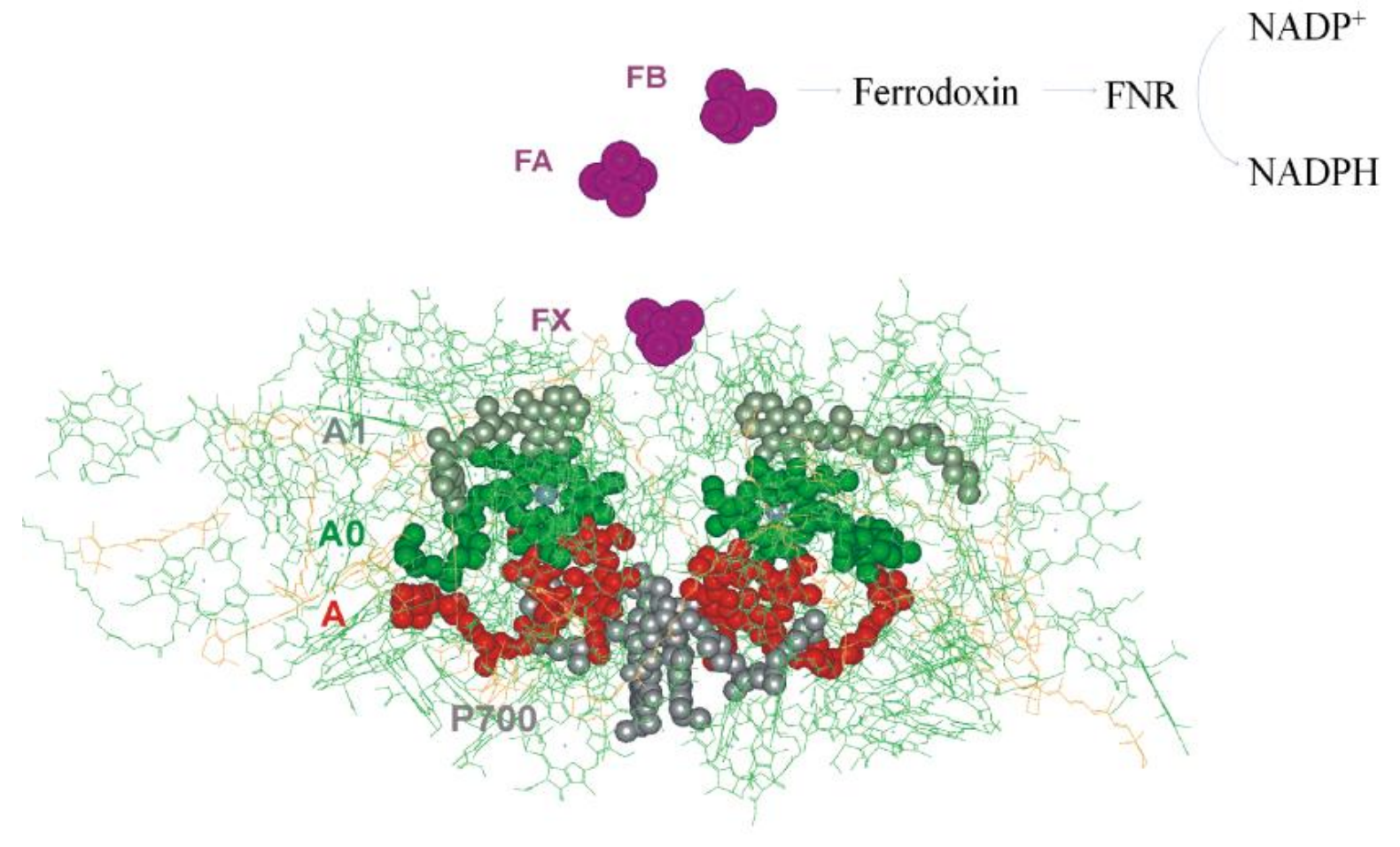

Figure 4: Electron transport chain in PSI RC.

Major participants: P700, grey; $A$ and $A_{0}$, red and green, respectively; $A_{1}$, pale green; FX, FA and FB (magenta). The figure was created by the software DSV and the PDB file 1JB0 (Jordan et al. 2001). 


\subsection{Carotenoids}

Carotenoids represent the most fascinating, abundant and widely distributed classes of natural pigments. From photosynthetic organisms to anoxygenic bacteria through cyanobacteria, algae and higher plants (Frank and Cogdell 1996), as well as numerous nonphotosynthetic bacteria and fungi (Goodwin 1980) produce carotenoid pigments. Until now, more than 700 naturally-occurring carotenoid pigments have been identified (Britton et al. 2004).

\subsubsection{Chemical structure and some physiological properties of carotenoids}

Their structures are consistent with the assumption that they are produced by joining together isoprene units, usually in a "head to tail" fashion. Isoprene is the common name for 2-methyl-1,3-butadiene. Most naturally occurring carotenoid pigments are tetraterpens (eight isoprene units) (Fig. 5). A very important property of carotenoids, both from spectroscopic and structural points of view, is the presence of double bonds in conjugated system which forms the chromophore responsible for the molecule color. A conjugated double bond system of a polyene longer than nine is responsible for the pigment properties of carotenoids (Fig. 5) (Gruszecki and Strzalka 2005). The conjugated double bond system constitutes a rigid, rodlike skeleton of carotenoid molecules. This feature seems to play a key role in the stabilization function of carotenoids, both with respect to lipid membranes and proteins. 


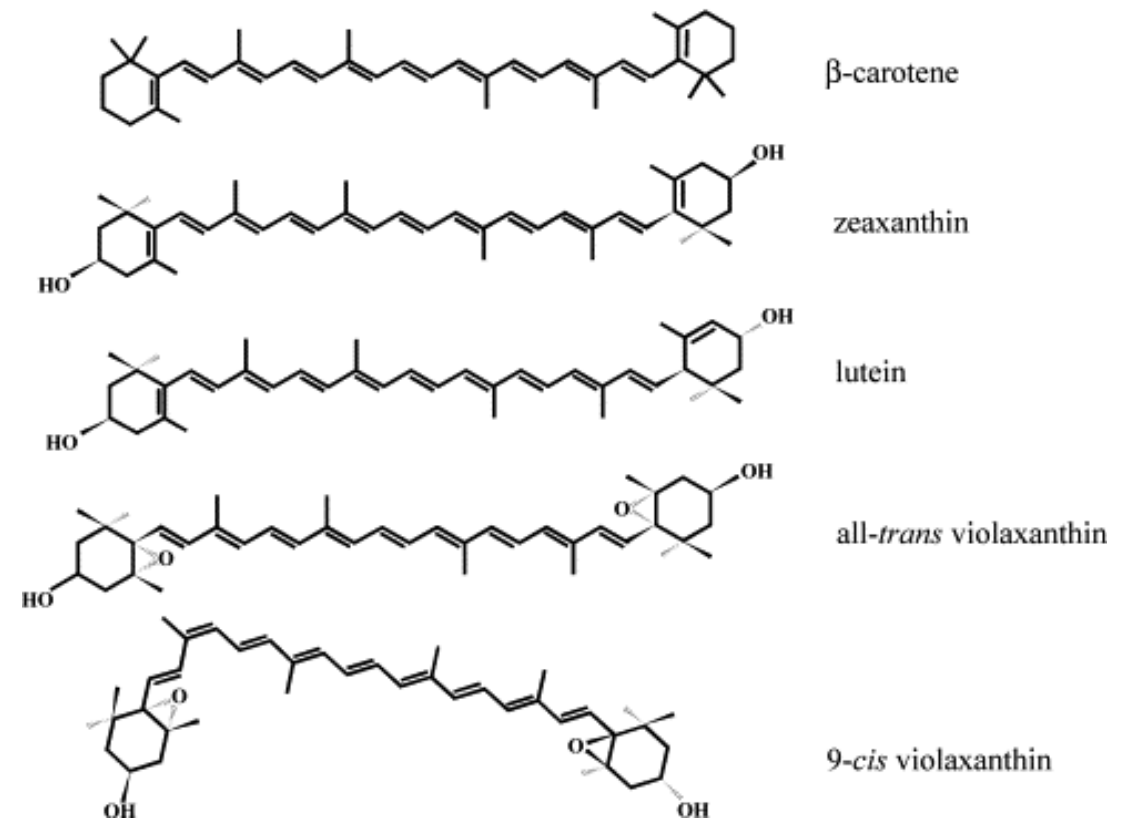

Figure 5: Chemical formulas of serial carotenoid pigments

All-trans- $\beta$-carotene, zeaxanthin, lutein, violaxanthin and 9-cis- violaxanthin

Carotenoids are classified in two subgroups, carotenes and xanthophylls. Carotenes are pure hydrocarbons with cyclic ionone rings at one or at two sides. $\beta$-carotene which is responsible for the orange color in plants and animals is the most known carotene (Fig. 5). In several cases, the cyclic ionone rings at one or at both sides are complemented with oxygen functional groups such as hydroxy, keto or epoxy (Fig. 5). These oxygenated carotene derivatives are called xanthophylls. Since carotenes are hydrocarbons without any polar group, they are fat-soluble and extremely hydrophobic, non-polar molecules. In contrast to xanthophylls, which contain polar groups, carotenes are hardly soluble in water. Thus, carotenes are expected to be restricted to hydrophobic region in the cell, such as the inner core of membranes, except in association with a protein, which allows them to access the aqueous phase. Obviously, polar functional groups alter the polarity of carotenoids and affect their interactions with other molecules (Britton 1995a).

In general, carotenoids may exist as different stereoscopic isomers. Each double bond can exist in trans- or cis- configuration (Goodwin 1980). In nature carotenoids exist primarily in the thermodynamically more stable all-trans- configuration rather than in cisconfiguration. It has been well-documented that polar carotenoids, in the all-transconfiguration, are linear, rigid molecules and they are effective modulators of the fluidity of 
natural and model lipid membranes (Gruszecki and Strzalka 2005). The cis-isomers, however, are not simple linear molecules. Their overall shape differs substantially from that of the all-trans form, so their ability to fit into subcellular structures is greatly altered. The tendency of $c$ is-isomers to crystallize or aggregate is usually much less; therefore cis-isomers may be more readily solubilized, absorbed, and transported than their all-trans- counterparts (Widomska et al. 2009). Minor cis-isomers can be regarded as products of chemical, thermal and photo isomerization (Molnar and Szabolcs 1993, Masamoto et al. 2004).

\subsubsection{Functional roles of carotenoids in photosynthesis}

\subsubsection{Light harvesting}

In photosynthesis, carotenoids act as accessory antenna pigments by absorbing light energy in the blue-green region of the solar spectrum (approximately between 400-550 nm). Absorption of UV radiation by a carotenoid molecule excites it from a vibrational level in the electronic ground state $\left(\mathrm{S}_{0}\right)$ to vibrational levels in the excited singlet state $\left({ }^{1} \mathrm{Car} *\right)$ (all electrons in the molecule are spin-paired), (1). Classically, carotenoid photophysics has been interpreted in terms of two low-lying excited singlet states, called $S_{2}$ and $S_{1}$ (Frank and Cogdell 1996). Due to the selection rules, the one photon allowed transition from the ground state goes to $S_{2}$. Then $S_{2}$ internally is converted to $S_{1}$ by dissipating the excess energy as heat (Kandori et al. 1994). Then the decay from $S_{1}$ to $S_{0}$ occurs. Carotenoids can donate energy from their both lowest singlet excited states $S_{1}$ and $S_{2}$ to the neighboring $\mathrm{Chl}$ and excite it to the level of the singlet excited state $\left({ }^{1} \mathrm{Chl}^{*}\right)$, the so called singlet-singlet energy transfer (2). The overall efficiency of this energy transfer varies from organism to organism. Singletsinglet energy transfer which depends on the antenna complex involved, is either from $\mathrm{S}_{2}$ to the Chl $\mathrm{Q}_{\mathrm{x}}$ singlet excited state or from $\mathrm{S}_{1}$ to the $\mathrm{Chl} \mathrm{Q}_{\mathrm{y}}$ singlet excited state (Ritz et al. 2000); in some complexes, both pathways are active (Macpherson et al. 2001).

Carotenoids orient nearby $\mathrm{Chl}$ in precise configurations that are designed for optimal singlet energy capture and efficient migration of excitation energy with minimal energy losses (van Amerongen and van Grondelle 2001). The Chl subsequently transfers the excitation energy to the $\mathrm{RC}$ where it is used to induce a charge separation (3).

The above mechanisms involved in light-harvesting are briefly shown as follows: 
Carotenoid $+h v \rightarrow{ }^{1}$ Carotenoid*

Singlet-singlet energy transfer:

${ }^{1}$ Carotenoid $^{*} \rightarrow{ }^{1} \mathrm{Chl} *$

Then,

${ }^{1} \mathrm{Chl}^{*} \rightarrow{ }^{1} \mathrm{P} 680^{*} \rightarrow \mathrm{P}^{2} 80^{+} / \mathrm{Pheo}^{-}$

\subsubsection{Photoprotection}

Under excess light conditions carotenoids quench singlet excited state Chl (Horton et al. 1996). The effect of excess light on a photosynthetic organism can be extremely harmful. In fact, the absorption of excess light required for maximum $\mathrm{CO}_{2}$ fixation will lead to the formation of a rather long lifetime triplet excited state $\mathrm{Chl}\left({ }^{3} \mathrm{Ch}{ }^{*}\right)$ (one set of electron spins is unpaired) (1) which can react with molecular oxygen and can produce excited singlet oxygen $\left({ }^{1} \mathrm{O}_{2}^{*}\right)(5)$, a very reactive oxygen species (ROS) formed mainly in PSII RC (Knox and Dodge 1985). The photooxidative damage may result in oxidation of lipids (Havaux et al. 1996), proteins and pigments (Formaggio et al. 2001), which can lead to photoinhibition of the photosynthetic machinery and to photobleaching. At this point, carotenoids can act in two ways: either by quenching the triplet excited state of Chl (2) (Schodel et al. 1999) or by directly scavenging the singlet excited state oxygen, which can induce interaction of triplet excited state of Chl with molecular oxygen (3), (Farmilo and Wilkinson 1973). This capacity relies on the photoprotection property of the carotenoid triplet state $\left({ }^{3}\right.$ Carotenoid*), whose energy is sufficiently low to effectively quench triplet state $\mathrm{Chl}$ and singlet state oxygen (Polivka and Sundstrom 2004).

In PSII RC, $\beta$-carotenes are not in close contact with P680, hence they cannot quench triplet excited state of P680 $\left({ }^{3} \mathrm{P} 680^{*}\right)$ by triplet-triplet transfer instead scavenge the singlet excited state oxygen, which is formed by the interaction of the triplet excited state of P680 with molecular oxygen. In both cases triplet excited carotenoids are formed and then relax to their ground state by heat dissipation (4). For an efficient triplet-triplet transfer between Chl 
and carotenoid both molecules must be positioned in close contact with each other (Cogdell and Frank 1987), which is maintained by the proteins, via coordinating pigments.

The above-mentioned mechanisms involved in carotenoid protection are briefly summarized as follows:

$$
\mathrm{Chl}+h v \rightarrow{ }^{1} \mathrm{Chl}{ }^{*} \rightarrow{ }^{3} \mathrm{Chl}^{*}
$$

Triplet-triplet energy transfer:

${ }^{3} \mathrm{Chl} *+$ Carotenoid $\rightarrow \mathrm{Chl}+{ }^{3}$ Carotenoid $*$

Or,

${ }^{1} \mathrm{O}_{2} *+$ Carotenoid $\rightarrow{ }^{3}$ Carotenoid $*$

Then,

${ }^{3}$ Carotenoid $* \rightarrow$ Carotenoid + heat $\rightarrow \quad$ photoprotection

Otherwise,

${ }^{3} \mathrm{Chl} *+\mathrm{O}_{2} \rightarrow{ }^{1} \mathrm{O}_{2} *+\mathrm{Chl} \quad$ photoinhibition

\subsubsection{Membrane structure organization}

Several recent studies indicate that protection of biomembranes against oxidative damage can be also rendered via modification of the physical properties of the lipid phase of the membranes. The hydrophobic core of biomembranes composed of polyunsaturated fatty acids is a potential target of ROS which may directly lead to membrane degradation. The protection against ROS is one of the main biological functions of carotenoids. A direct effect of carotenoid pigments particularly on structural and dynamic properties of lipid membrane is a significant decrease in the lipid-membrane susceptibility to oxidative degradation (Cogdell and Frank 1987, Gruszecki and Strzalka 2005). The effect of carotenoids on the modulation of physical properties of lipid membranes is the result of the carotenoid-lipid interactions therefore highly depends on the physiological properties of the lipids composing the membrane and embedded carotenoids. The presence of hydroxyl groups which are anchored at the opposite sides of lipid bilayers in the carotenoid molecule seems to significantly affect 
the membrane properties by modulating membrane fluidity and forming penetration barrier of small molecules, including oxygen (Berglund et al. 1999).

\subsection{Model Organism: Cyanobacterium Synechocystis sp. PCC 6803}

Cyanobacteria are remarkably resistant organisms that inhabited almost all environments where light is available, ranging from freshwater, marine and terrestrial environments to extreme environments such as hot springs, deserts and Antarctica.

They are regarded as the origin of plant chloroplasts originated by endosymbiosis due to their ability to perform the oxygen-evolving photosynthesis, a characteristic of photosynthetic eukaryotes. Cyanobacteria were formerly named as blue-green algae based on the provisions of the Botanical Code, but they are in fact prokaryotes, lacking internal organelles, and having cell wall (Rippka et al. 1979).

Cyanobacteria are amenable to genetic manipulation. Some strains are naturally transformable. The transformability of cyanobacteria is determinant in the development of the molecular biology of these organisms. Genomes of the most popular cyanobacteria have been analyzed extensively and complete genome sequencing data for various strains are now available. Their unique photosynthetic abilities combined with their usefulness as experimental model organisms have made cyanobacteria popular photosynthetic subjects for genetic and physiological studies.

Synechocystis is one of the most highly studied cyanobacteria which can grow both in photoautotrophic and heterotrophic conditions in the absence of light. Complete genomic sequences have been obtained for the Synechocystis by Dr. Satoshi Tabata and coworkers (Nakamura et al. 1996). It is transformable at high efficiency and integrates DNA by homologous double recombination. The photosynthetic apparatus is very similar to that found in higher plants.

\subsection{Biosynthetic pathway of carotenoids in Synechocystis}

Farnesyl pyrophosphate $\left(\mathrm{C}_{15)}\right.$ (FPP) is synthesized from three isopentenyl pyrophosphates (IPPs) by IPP isomerase. Then one IPP $\left(\mathrm{C}_{5}\right.$-isoprenoid units) is added to farnesyl pyrophosphate by geranylgeranyl pyrophosphate synthase (CrtE) to yield geranylgeranyl pyrophosphate $\left(\mathrm{C}_{20}\right)(\mathrm{GGPP})$. During a condensation of the two $\mathrm{C}_{20}$ compounds, the first carotene of 15-cis-phytoene $\left(\mathrm{C}_{40}\right)$ is formed by phytoene synthase (CrtB). Geranylgeranyl pyrophosphate synthase (CrtE) and phytoene synthase (CrtB) 
(Martinez-Ferez et al. 1994) are the first enzymes of carotenoid biosynthesis in Synechocystis (Fig. 6). The subsequent conversion of phytoene to $\beta$-carotene requires desaturases and cyclases steps. Phytoene desaturase (CrtP), (Martinez-Ferez and Vioque 1992) converts 15-cis-phytoene to $c i s$ - $\zeta$-carotenes via 15 -cis-phytofluene, $\zeta$-carotene desaturase (CrtQ), (Bautista et al. 2005a) converts all-trans- $\zeta$-carotenes to cis-lycopene via cis-neurosporene) (Fig. 6). Cis-to-trans carotene isomerase (CrtH) or light (Masamoto et al. 2001) converts cis-carotenes to all-trans-lycopene (Fig. 6).

All trans-lycopenes are cyclized to $\beta$-carotene via $\gamma$-carotene. There are two possible branching points in the synthesis of $\beta$-carotene and its derivatives, and myxoxanthophyll. One is at lycopene, where two lycopene cyclases may be present: lycopene $\beta$-cyclase, which produces $\beta$-carotene, and lycopene monocyclase, which produces only $\gamma$-carotene for myxoxanthophyll. The other possible branching point is at $\gamma$-carotene: lycopene cyclase produces $\beta$-carotene via $\gamma$-carotene, which is also used for myxoxanthophyll synthesis. In any case, the branching points are still unknown (Takaichi and Mochimaru 2007). $\beta$-carotene is further modified by the enzymes such as $\beta$-carotene ketolase ( $\mathrm{CrtO}$ ) (Fernandez Gonzalez et al. 1997) and $\beta$-carotene hydroxylase (CrtR) (Lagarde and Vermaas 1999). CrtO catalyzes $\beta$ carotene to echinenone (Fernandez Gonzalez et al. 1997). CrtR catalyzes $\beta$-carotene to zeaxanthin via $\beta$-cryptoxanthin, and echinenone to 3-hydroxyechinenone and deoxymyxol 2dimethyl-fucoside to myxoxanthophyll (Masamoto et al. 1998, Lagarde and Vermaas 1999, Takaichi et al. 2001). 


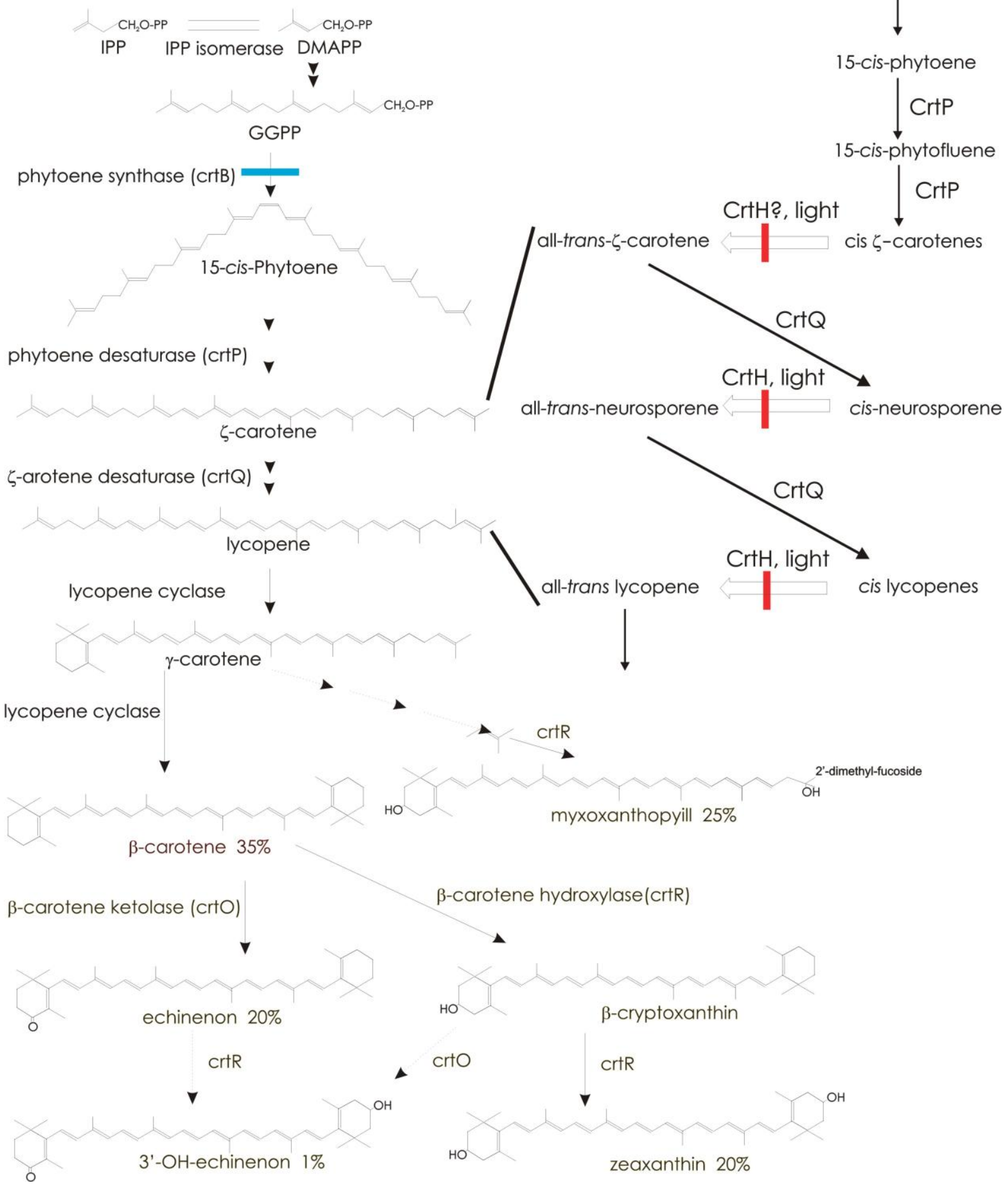

\section{Figure 6: The pathway of carotenoid biosynthesis in Synechocystis}

General carotenoid biosynthesis pathway together with accumulated end-products: $\beta$ carotene, zeaxanthin, echinenone, 3'hydoxyechonenone and myxoxanthophyll. Blue line indicates the inactivation of $c r t B$ gene. On the right side: A putative carotenogenesis pathway from 15-cis-phytoene to all-trans-lycopene. Red line indicates the inactivation of $\mathrm{crtH}$ gene. 


\subsection{Localization of carotenoids in photosynthetic complexes}

\subsubsection{Localization of $\beta$-carotene molecules in photosystem II}

Twelve carotenoids were found in monomeric PSII complex of T. elongates by Xray crystallographic analysis (Guskov et al. 2009) All carotenoid molecules were identified as $\beta$-carotene in all-trans-configuration (Loll et al. 2005, Guskov et al. 2009). Recently, the absorption spectroscopy of redissolved crystals confirmed $11 \beta$-carotene molecules (Guskov et al. 2010), the missing one $\beta$-carotene in the structure of the monomeric PSII is located actually at the monomer-monomer interface in dimeric PSII and therefore may detach due to its exposed localization in the monomer (Guskov et al. 2010). The best characterized $\beta$ carotene molecule is in the monomeric PSII which is close D2 and Cyt $b$-559 (Guskov et al. 2010). The almost identical structure of monomeric and dimeric PSII is also reflected by the location of the tetrapyrrole cofactors and the non-heme iron. In agreement with this finding, the presence of $11 \beta$-carotene at positions expected from dimeric PSII could also be confirmed in monomeric form (Guskov et al. 2010). As five of all $\beta$-carotene molecules in the dimeric PSII are located at the monomer-monomer interface it is remarkable that only one of these five molecules is missing in the monomeric form (Fig. 7). This $\beta$-carotene is found in a bridging position across the monomer-monomer interface (Fig. 7), (Guskov et al. 2010).

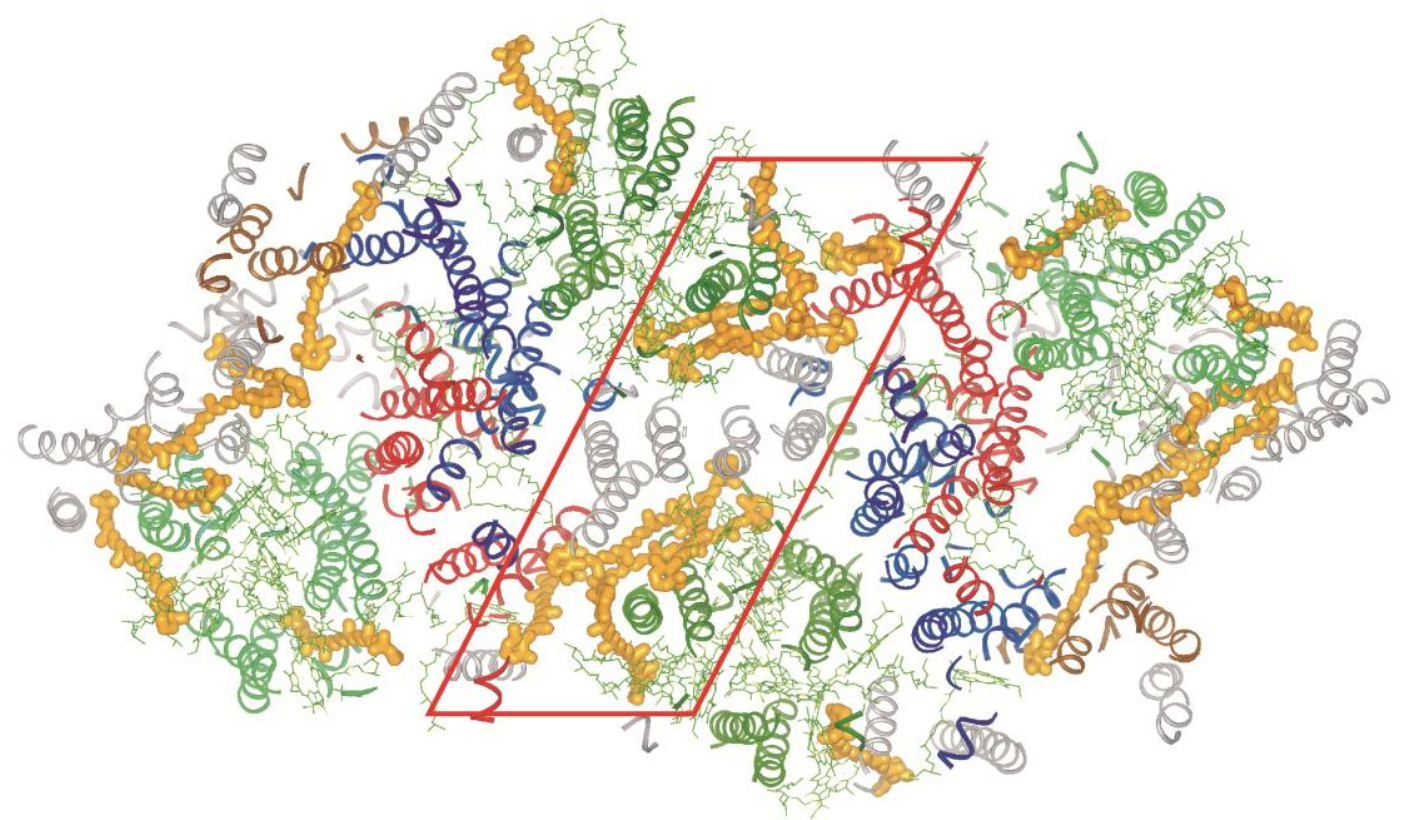

Figure 7: Stromal side view of $\beta$-carotene molecule localization on the monomermonomer interface

Red frame emphasizes $5 \beta$-carotene molecules (orange) located on the monomer-monomer interface. The figure was created by the software DSV and the PDB files 3BZ1 and 3BZ2 (Guskov et al. 2009) 
Only two $\beta$-carotenes are structurally related to the D1 and D2 protein subunits, five are associated with CP47 and four with CP43 (Fig. 8). Most of the $\beta$-carotene molecules associated with CP47 are clustered at the monomer-monomer interface between CP47 of one monomer and D1 and PsbT of the other monomer. A number of $\beta$-carotene molecules at the outside of the dimeric PSII core complex is nestled between transmembrane helices of the large and small membrane intrinsic protein subunits, so that PsbF, PsbH, PsbJ, PsbK and PsbZ are apparently involved in carotenoid binding (Fig. 8) (Muh et al. 2008).

Three Chl $a$ in CP47 and two Chl $a$ in CP43 are in close contact with carotenoids. Thus, an efficient quenching of excited triplet states become possible (Muh et al. 2008). Five carotenoid molecules are in close contact with each other and are possibly coupled for fast electron and/or exciton transfer (Guskov 2009).

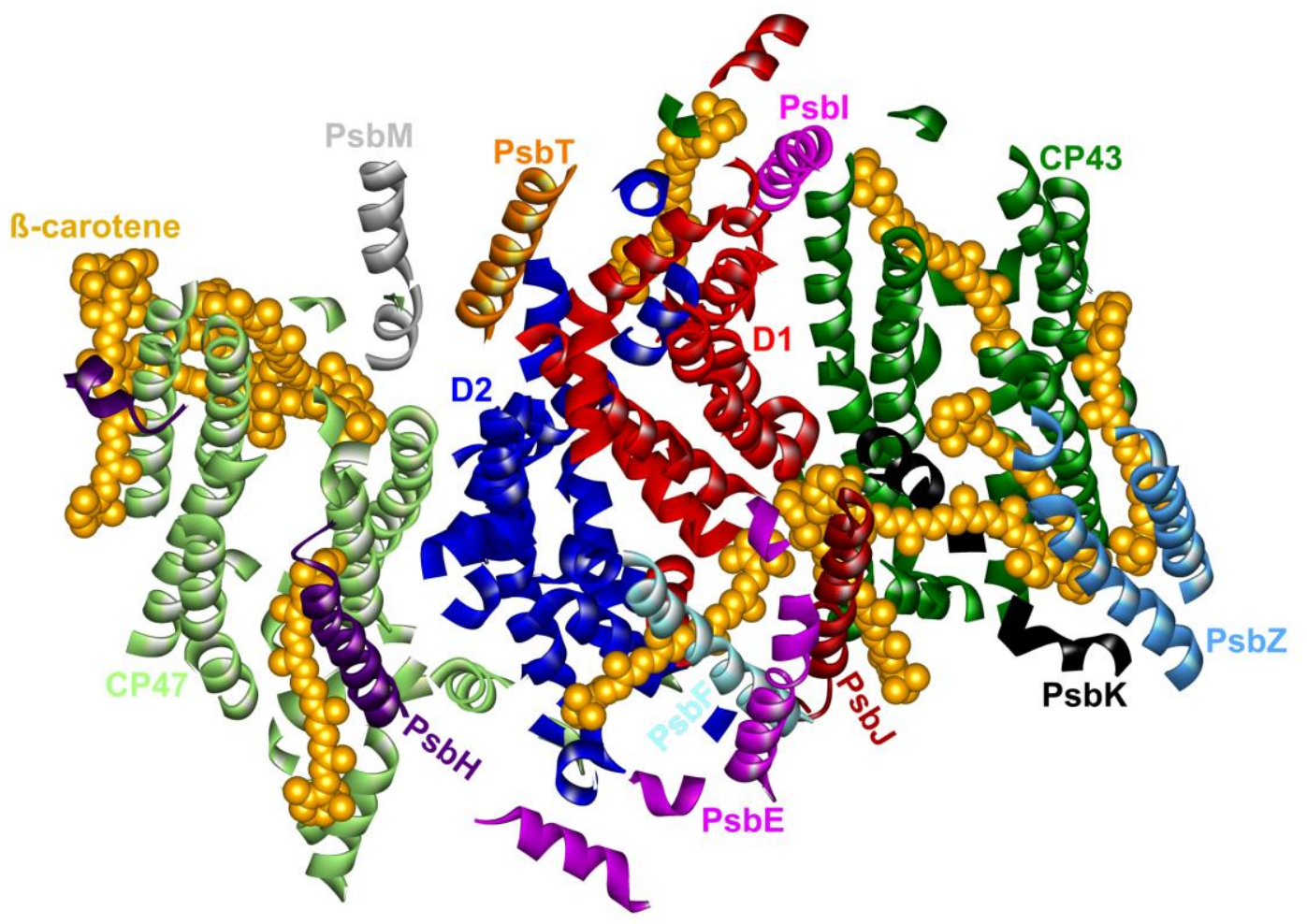

Figure 8: Stromal side view of $\beta$-carotene and membrane-intrinsic protein subunits localization in the monomeric PSII complex.

Orange, $\beta$-carotene; red, D1; navy, D2; light green CP47; dark green, CP43; purple, PsbH; light blue, PsbF; magenta, PsbE, orange, PsbT; dark red, PsbJ; black, PsbK; dark blue, PsbZ; violet, PsbI; grey, PsbM. The figure was created by the software DSV and the PDB file 3BZ1 (Guskov et al. 2009). 


\subsubsection{Localization of a $\beta$-carotene molecule in cytochrome $b_{6} f$}

The crystallographic structure of the Cyt $b_{6} f$ complex from the filamentous cyanobacterium Mastigocladus laminosus, Nostoc sp. PCC 7120 exhibited stoichiometrically bound $\mathrm{Chl} a$ and $\beta$-carotene at a ratio of approximately one molecule of each per Cyt $f$ (Baniulis et al. 2009). A 9-cis- $\beta$-carotene molecule which is in agreement with Raman spectra results is inserted near the center of the transmembrane region between the PetL and PetM helices, in contact with the PetB, PetE, and PetG helices (Kurisu et al. 2003). It is oriented obliquely to the membrane plane and Chl $a$. It is too far from Chl $a$ for effective quenching of the excited triplet state Chl $a$ (Cramer et al. 2006).

\subsubsection{Localization of $\beta$-carotene molecules in photosystem I}

Twenty two carotenoids have been identified in the structure of monomeric PSI from T. elongatus (Jordan et al. 2001, Fromme et al. 2001, Grotjohann and Fromme 2005) (Fig. 9). They were modelled as $\beta$-carotene (Jordan et al. 2001) which has been previously shown as the dominant carotenoid in PSI (Palsson et al. 1998). Seventeen carotenoid molecules showed the all-trans configuration, 2 are 9-cis, and 3 contain one of 9, 9'-cis 9, 13'-cis and 13-cis bonds. The 'fit-into-space' consideration would be the easiest explanation for the incorporation of the cis-carotenoids. Other options may include the possibilities that there may be a different efficiency for quenching for the cis- and trans-carotenoids, due to the higher energy level for the cis- compared to the trans- carotenoids (Grotjohann and Fromme 2005).

According to crystallographic structure of T. elongatus (Jordan et al. 2001, Grotjohann and Fromme 2005), six carotenoid clusters are present in PSI. Four of six clusters are associated with PsaA and PsaB, and contain three, three, two and two carotenoids, respectively. Cluster five contains six carotenoid molecules and interacts with PsaA, PsaB, PsaF and PsaJ and is located peripherally, on the outside of the complex. Cluster six contains also six carotenoids and is near a trimeric axis and participates in hydrophobic contacts with PsaA, PsaB, PsaI, PsaL and PsaM. 


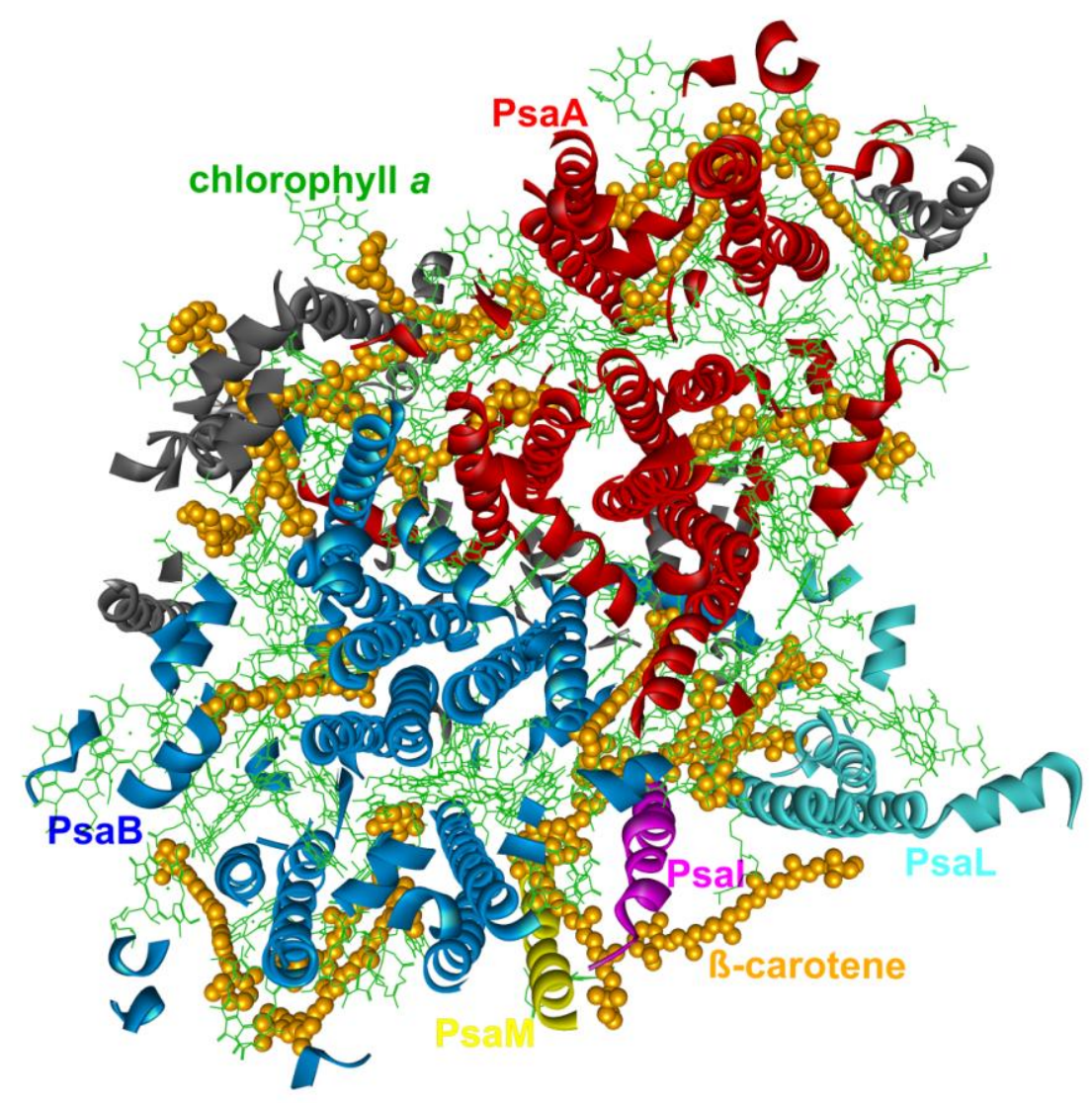

Figure 9: Lumenal side view of the $\beta$-carotene molecules localization in the monomeric PSI complex

Orange, $\beta$-carotene; red, PsaA; blue, PsaB; light blue, PsaL; magenta, PsaI, yellow, PsaM and dark green, chlorophyll $a$ pigments. The figure was created by the software DSV and the PDB file 1JB0 (Jordan et al. 2001).

The majority of the carotenoids are deeply inserted into the hydrophobic region of membrane, and only a few of the head groups located closer to the stromal or luminal side. In PSI, all carotenoids are in direct vicinity to Chl $a$ head groups and they are in van der Waals contacts with them. More than 60 of the $96 \mathrm{Chl} a$ are in close contact with carotenoids, thereby facilitating efficient triplet quenching and energy transfer (Fromme et al. 2001).

\subsection{Phosphatidylglycerol in photosynthesis}

. Lipid-protein and lipid-pigment interactions play an important role in the regulation of pigment-protein complexes embedded in thylakoid membrane (Gruszecki and Strzalka 2005). Thylakoid membrane of cyanobacteria possesses a characteristic membrane lipid composition that consists of glycolipids and phospholipid. In cyanobacteria and in the thylakoid membrane of higher plants, phosphatidylglycerol (PG) is the only phospholipid. 
The recent X-ray crystallographic structure of $T$. elongatus showed that there are PG molecules in PSII complex localized between CP43 and D1 (Guskov et al. 2009) as well as in PSI (Jordan et al. 2001).

\subsection{Earlier studies on carotenoid mutants in cyanobacteria}

The major carotenoids in Synechocystis are $\beta$-carotene; its hydroxyl derivative, zeaxanthin; its keto derivative, echinenone and 3 'hydroxyechinenone and the carotenoid glycoside, myxoxanthophyll (Britton et al. 2004, Takaichi and Mochimaru 2007) (Fig. 6). In the $\Delta c r t O$ mutant, absence of echinenone affected photosynthetic electron transport to only a small extent (Fernandez Gonzalez et al. 1997). In contrast, $\Delta c r t R$ lacking both zeaxanthin synthesis and myxoxanthophyll accumulation resulted in strong photoinhibition of overall photosynthetic electron transport as well as the PSII activity under high light treatment (Schäfer et al. 2005). However, $\Delta c r t R$ showed that these two missing carotenoids are not required for the assembly of RCs (Steiger et al. 1999). In the double mutant $\Delta c r t R O$ (Schäfer et al. 2005) the effect was additive. The oxygen-evolving activity and maximum quantum yield of PSII dramatically dropped under high-light treatment. Moreover, the remaining $\beta$ carotene and modified myxoxanthophyll are not able to protect the photosynthetic machinery. $\Delta c r t H$, cis- to trans-isomerase mutant (Masamoto et al. 2001), under light-activated heterotrophic growth (LAHG) conditions (described in materials and methods), produced primarily cis-lycopenes and small amounts of all-trans carotenes, which are intermediate carotenes for all-trans lycopene synthesis, but no xanthophylls. Under light conditions, however, this mutant produced all carotenoids which are typical for wild-type strain (Masamoto et al. 2001). $\Delta c r t H$ can accumulate $\beta$-carotene under light conditions. However, the mutant cells grown under LAHG condition did not contain detectable levels of either $\beta$ carotene or D1 protein subunit and there were no oxygen-evolving activity of PSII observed. $\beta$-carotene and D1 protein subunit appeared and a high level of PSII activity was detected after the cells were transferred to continuous light condition. The PSI activity of $\Delta c r t H$ cells were almost the same as those of WT cells, both before and after transfer to continuous light. These results suggest that $\beta$-carotene is required for the assembly of PSII but not for that of PSI (Masamoto et al. 2004). Moreover, genetic manipulation of the carotenoid synthesis suggested that PSII assembly requires the presence of a carotenoid with at least one $\beta$ ionylidene ring, which may play a structural role in early stages of assembly (Bautista et al. 2005b). 
Cyanobacteria are well protected against stress-mediated photooxidation. They possess a well-balanced antioxidative system to cope with photoinhibition. Due to their antioxidative properties, carotenoids are essential for the protection of the photosynthetic apparatus against different stress conditions. The substitutions of the $\beta$-carotene molecule determine antioxidative properties (Britton 1995a). In general, hydroxy carotenoids efficiently scavenge peroxy radicals (Woodall et al. 1997b)_whereas keto derivatives are more efficient in quenching of reactive singlet oxygen (Woodall et al. 1997a) and possess efficient stability against peroxy radicals and photooxidation (Steiger et al. 1999). In Synechocystis, genetically modified cells containing over-expressed zeaxanthin were more efficient in photoprotection than the WT (Schäfer et al. 2005). Similar results obtained on Synechococcus PCC 7942 also support the efficient antioxidant activity of zeaxanthin, since UV-B stress increased the level of zeaxanthin (Gotz et al. 1999). Under high-light treatment of T. elongatus, the level of zeaxanthin was the highest and level of myxol glycoside greatly increased while there were only minor alterations in the level of $\beta$-carotene (Kilian et al. 2007). Investigations on the photoprotective function of myxoxanthophyll in the cyanobacterium Plectonema boryanum cells exposed to UV radiation revealed a reduced efficiency of energy transfer to PSII RCs and an elevated level of myxoxanthophyll (Ivanov et al. 2000). Another stress factor that can generate elevated levels of carotenoids is low temperature stress. Low temperature stress increased the myxoxanthophyll content of Cylindrospermopsis raciborskii cells (Várkonyi et al. 2002). Carotenoids are known to affect the structure of photosynthetic membranes (Gruszecki and Strzalka 2005). Stress-induced carotenoid accumulation was observed in both thylakoid and cytoplasmic membranes (Masamoto and Furukawa 1997, Masamoto et al. 1999).

Other photoprotective mechanism involves down-regulation of photosynthesis by increasing thermal dissipation of the energy absorbed by the PSII antenna. While this process has been well studied in plants, the equivalent process in cyanobacteria was only recently discovered (Kerfeld 2004, Wilson et al. 2006). The orange carotenoid protein (OCP) binding 3'hydroxyechinenone as well as echinenone (Punginelli et al. 2009) is the key inducer of this photoprotective mechanism. Light causes structural changes within both carotenoids and the proteins, leading to the conversion of an orange inactive form into a red active form. The activated red form induces an increase of energy dissipation leading to a decrease in the fluorescence of the PBSs, the cyanobacterial antenna, and thus of the energy arriving to the RCs. The OCP, which senses light and triggers photoprotection, is a unique example of a 
photoactive protein containing a carotenoid as the photoresponsive chromophore in cyanobacteria (Wilson et al. 2010).

Studies on Synechocystis cells demonstrated that PG plays an important role in oxygen evolution (Hagio et al. 2000), in the formation of dimeric PSII (Sakurai et al. 2003), and in the formation of trimeric PSI (Domonkos et al. 2004). PG depletion resulted in a decrease of the Chl content and a suppression of electron transport from $\mathrm{Q}_{\mathrm{A}}$ to $\mathrm{Q}_{B}$, which may lead to over-reduction of $\mathrm{Q}_{\mathrm{A}}$ and to the generation of $\mathrm{Q}_{\mathrm{A}}{ }^{2-}$ (Gombos et al. 2002, LaczkóDobos et al. 2008) indicating the general slowdown of the photosynthetic processes. PG plays an essential role against low temperature stress (Murata et al. 1982, Murata 1983, Moon et al. 1995) and high light stress (Vass et al. 1992). 


\subsection{AIMS}

Changes in global environment might lead to stress conditions in photosynthetic organisms and limit the efficiency of photosynthesis. Understanding photosynthesis and its protective mechanisms might lead to the development of plant, algae and cyanobacteria with improved growth characteristics even under stress conditions. Cyanobacteria, our model organisms, are regarded as an origin of the plant chloroplast; therefore they are excellent to study higher plant photosynthesis. Carotenoids are very important protective agents in photosynthesis due to their anti-oxidative properties against photooxidative damage. Their structural and functional features in protection mechanisms are not completely elucidated yet. Complete genome sequences and the transformability of several cyanobacterial strains allow us to generate various mutants and study the importance of carotenoids in photosynthetic processes. Therefore, the aims of my thesis are:

I. To generate the first viable oxygenic photosynthetic prokaryotic in the cyanobacterium Synechocystis sp. PCC 6803, which is completely deficient in carotenoid synthesis in order to study, for the first time, in vivo:

i. The structural consequences of carotenoid deficiency on the assembly of the photosynthetic complexes

ii. The functional consequences of carotenoid deficiency on the activity of the photosynthetic reaction centers

II. Studying how carotenoids respond to stress conditions other that light stress; to this end PG depletion was induced in the Synechocystis sp. PCC 6803 pgsA strain. 


\subsection{MATERIALS AND METHODS}

\subsection{Construction of Synechocystis $\Delta c r t H / B$ mutant}

In order to generate the carotenoid deficient mutant, partial carotenoid deficient $\Delta c r t H$ cells were used as a host strain due to their adaptation to partial carotenoid deficiency and LAHG conditions (check in 3.2) that could increase the probability of transformation. Restriction enzymes $B g l \mathrm{II}$ and $\operatorname{Not} \mathrm{I}$ were used to cut the cosmid clone cs0798 (http://genome.kazusa.or.jp/cyanobase/Synechocystis/map/Chr/orf16) provided by S. Tabata. A $7.7 \mathrm{~kb} B g l \mathrm{II}$ fragment containing the phytoene synthase encoding $\operatorname{crt} B$ gene of Synechocystis was cloned into the BamHI site of pMPMA2 (Mayer 1995). A part of the crtB gene coding region was removed by ApaI-HindIII digestion and replaced with an omega cassette. Transformants were selected under LAHG conditions on BG11 agar plates supplemented with glucose and increasing amount of spectinomycin by several restreaking of single colonies. Complete segregation of $\Delta c r t H / B$ cells was confirmed by PCR using the primers crtBup (5'-CGGTGCCCAACTTTTACCTA-3'), and crtBdown (5'TCACCTAAGGGGAAACATCG-3').

\subsection{Organisms, growth conditions and light treatment}

The mutant strains used in this study were derived from the glucose-tolerant strain of Synechocystis $\Delta c r t H$, and $\Delta c r t H / B$ strains were grown at $30{ }^{\circ} \mathrm{C}$ in $\mathrm{BG} 11$ medium (Allen 1968) supplemented with $5 \mathrm{mM}$ HEPES buffer ( $\mathrm{pH}$ 7.5) and $10 \mathrm{mM}$ glucose under lightactivated heterotrophic growth (LAHG) conditions (Anderson and McIntosh 1991). In LAHG, the cells grown in the dark were supplied by white fluorescent lights for 10 min once a day at an intensity of $15 \mu \mathrm{mol}$ photons $\mathrm{m}^{-2} \mathrm{~s}^{-1}$. For low-light treatment the cells were treated at $35 \mu \mathrm{mol} \mathrm{m} \mathrm{m}^{-2} \mathrm{~s}^{-1}\left(50 \mu \mathrm{mol}\right.$ photons $\mathrm{m}^{-2} \mathrm{~s}^{-1}$ only for protein analysis) and for high-light treatment the cells were treated at $500 \mu \mathrm{mol}$ photons $\mathrm{m}^{-2} \mathrm{~s}^{-1}$. Forty $\mu \mathrm{g} \mathrm{ml}^{-1}$ kanamycin and 40 $\mu \mathrm{g} \mathrm{ml}^{-1}$ spectinomycin, and $20 \mu \mathrm{g} \mathrm{ml}^{-1}$ kanamycin were added to the medium of $\Delta c r t H / B$ and $\Delta c r t H$ cells, respectively. Cultures were aerated on a gyratory shaker at $100 \mathrm{rpm}$.

Synechocystis pgsA mutant cells were grown photoautotrophically in BG11 medium (Allen 1968) supplemented with $5 \mathrm{mM}$ HEPES-NaOH (pH 7.5), $20 \mu \mathrm{g} \mathrm{ml}^{-1}$ kanamycin and $20 \mu \mathrm{M}$ dioleoyl-PG (18:1/18:1 PG) (P-9664, Sigma, St Louis, MO, USA) at $30^{\circ} \mathrm{C}$ under continuous illumination at a light intensity of $30 \mu \mathrm{mol}$ photons $\mathrm{m}^{-2} \mathrm{~s}^{-1}$. PG depletion was 
achieved by washing the cells twice with PG-free medium and keeping them afterwards in PG-free medium. Cultures were aerated on a gyratory shaker at $100 \mathrm{rpm}$.

\subsection{Chlorophyll content analysis}

Chlorophyll content analysis for HPLC measurements - Chl concentration was measured by absorbance at $665 \mathrm{~nm}$, using a 90\% methanol extract (Lichtenthaler 1987).

Chlorophyll content analysis for protein measurements - Sedimented cells or membranes were extracted with $100 \%$ methanol and the Chl content of the extract was calculated from the absorbances at $666 \mathrm{~nm}$ and $720 \mathrm{~nm}$ (Welburn and Lichtenthaler 1984).

\subsection{Carotenoid content analysis}

Synechocystis cells and subcellular fractions isolated from them were extracted with acetone:methanol $(7: 2 \mathrm{v} / \mathrm{v})$ and centrifuged for $3 \mathrm{~min}$ at $4{ }^{\circ} \mathrm{C}$ in a Sigma K-18 centrifuge $(20,000 \times g)$. The supernatant fluid was evaporated under nitrogen gas and the extracted pigments were dissolved in HPLC-grade ethanol.

Pigments were separated on a Prostar HPLC system (Varian, Miami, FL, USA), equipped with a photodiode array spectrophotometric detector Tidas I (World Precision Instruments, Sarasota, FL, USA) and a Nucleosil $100 \mathrm{C} 18$ reversed phase column, $5 \mu \mathrm{m}$ particle size (Technokroma, Barcelona, Spain), using the solvent system described by Lagarde and coworkers (Lagarde et al. 2000). Samples $(100 \mu \mathrm{l})$ were filtered through a stainless steel filter $(\varphi=0.22 \mu \mathrm{m})$ and loaded on the column equilibrated with Solvent A (acetonitril:water:triethylamine, 9:1:0.01 by vol.). The column was eluted with Solvent B (ethyl acetate $100 \%)$, by a three-step gradient $(0-40 \%$ B for $10 \mathrm{~min}, 40-60 \%$ B for $10 \mathrm{~min}$, $60-100 \%$ B for $3 \mathrm{~min}$ ) followed by an isocratic hold (2 min) at 100\% B. During separation, a constant flow rate of $1.5 \mathrm{ml} \mathrm{min}^{-1}$ was ensured. The absorption spectra of the eluates (380$800 \mathrm{~nm}$ ) were recorded every $0.2 \mathrm{~s}$.

Carotenoid derivatives were identified on the basis of both their absorption spectra and their retention times. The relative content of each pigment was estimated by a comparison of peak areas on chromatograms recorded at $440 \mathrm{~nm}$. The concentrations of carotenoid species and chlorophyll were calculated from Beer-Lambert's law using their specific extinction coefficients at $440 \mathrm{~nm}$ (Mantoura and Llewellyn 1983) and at $665 \mathrm{~nm}$ (Lichtenthaler 1987) (Only the echinenone was calculated at $460 \mathrm{~nm}$ (Britton 1995b)). Values are means \pm SD from at least three individual experiments. 


\subsection{Absorption spectroscopy}

Absorption spectra of cell suspensions were recorded with a UV-3000 (Shimadzu, Japan) spectrophotometer. The cell densities were adjusted to an identical optical density at $730 \mathrm{~nm}$. The absorption spectra of cell suspensions were scanned in the visible region from $400 \mathrm{~nm}$ to $800 \mathrm{~nm}$. All these absorption spectra were taken at room temperature and were not corrected for spectral sensitivity.

\subsection{Low-temperature (77 K) fluorescence spectroscopy}

Low temperature steady-state fluorescence emission spectra (600 to $800 \mathrm{~nm}$ ) were recorded at $77 \mathrm{~K}$ using an Aminco Bowman Series 2 luminescence spectrometer (Spectronic Unicam, USA). The cells were excited at $435 \mathrm{~nm}$. Spectra were corrected for the sensitivity of the photomultiplier and normalized to the maximum of PSI emission around $725 \mathrm{~nm}$.

\subsection{RNA isolation and Northern blot analysis}

Total RNA from Synechocystis WT and $\Delta c r t H / B$ cells grown under LAHG conditions was isolated using the hot phenol method (Mohamed and Jansson 1989), with the following modification: the first phenol extraction was done in a boiling water bath for $3 \mathrm{~min}$. Northern blot analysis was performed as described by Kis and coworkers (Kis et al. 1998). DNA probes were generated by PCR using Synechocystis genomic DNA and gene-specific primers as shown: $\quad p s b A \quad$ gene; F:5'-GACATCGACGGTATCCGTGAG-3, R:5'ACAGCAGGAGCGGTCAAAG-3'. psbDII gene; F:5'TGTCCTCGACGATTGGCTAAAG-3', R:5'-AAACCGACGATACCCACAGAAC-3'. psbDIC gene; F:5'-CTTGGTGGTCGGGAAATG-3', R:5'-GTGAAGGCTTGGGATTGG-3'. $p s b B$ gene; F:5' TGCCCACATCGTTCTATC-3', R: 5'-TGCGGAATACACCATCAG-3'. All membranes were probed also with the $\operatorname{rnpB}$ as loading and transfer control.

\subsection{Radioactive labeling of the cells}

For radioactive labeling, cells containing $75 \mu \mathrm{g}$ of Chl were resuspended in $250 \mu \mathrm{l}$ of BG11 in a microcentrifuge tube, shaken at $50 \mu \mathrm{mol}$ photons $\mathrm{m}^{-2} \mathrm{~s}^{-1}$ for $15 \mathrm{~min}$ and then a mixture of $\left[{ }^{35} \mathrm{~S}\right]$ Met and $\left[{ }^{35} \mathrm{~S}\right] \mathrm{Cys}$ (Trans-label, MP Biochemicals, Irvine, USA) was added (final specific activity $400 \mu \mathrm{Ci} \mathrm{ml}^{-1}$ ). The suspension was exposed to $50 \mu \mathrm{mol}$ photons $\mathrm{m}^{-2} \mathrm{~s}^{-1}$ white light for $15 \mathrm{~min}$ (pulse), then chloramphenicol $\left(1 \mathrm{mg} \mathrm{ml}^{-1}\right.$ final concentration) and a 
mixture of cold Met and Cys (5 $\mathrm{mM}$ final concentration) were added and incubation continued for an additional $15 \mathrm{~min}$ (pulse-chase). Afterwards the cells were frozen in liquid nitrogen and used for isolation of thylakoid membranes.

\subsection{Thylakoid membrane isolation}

Isolation of thylakoid membranes of $\triangle \mathrm{crtH} / \mathrm{B}$ cells -Thylakoid membranes were prepared by breaking the cells using glass beads according to Komenda et al. (2005) with the following modifications: the cells were washed, broken and resuspended in $25 \mathrm{mM}$ MES/NaOH, pH 6.5, containing $10 \mathrm{mM} \mathrm{CaCl}_{2}, 10 \mathrm{mM} \mathrm{MgCl}_{2}$ and 25\% glycerol. Glass beads were subsequently removed by filtering and thylakoid membranes were obtained by differential centrifugation

Isolation of thylakoid and cytoplasmic membranes of pgsA cells- Thylakoid and cytoplasmic membranes were isolated (Murata and Omata 1988), with some modifications. The $0.2 \%$ lysozyme-treated $\left(37^{\circ} \mathrm{C}, 2 \mathrm{~h}\right)$ and pelleted cells were disrupted with $0.1 \mathrm{~mm}$ glass beads in a Bead Beater homogenizer (Biospec Products, Bartlesville, OK, USA) in the presence of $1 \mathrm{mM}$ phenylmethylsulfonyl fluoride (PMSF) protease inhibitor. The disrupted cells were treated with $0.1 \%$ DNase for $15 \mathrm{~min}$, and the unbroken cells were removed by centrifugation $(10 \mathrm{~min}, 7,000 \times g)$. The membrane vesiculi were ultracentrifuged in a discontinuous sucrose density gradient $\left(130,000 \times g, 16 \mathrm{~h}, 4^{\circ} \mathrm{C}\right)$. After flotation centrifugation, the cytoplasmic membranes formed a yellow band in the $30 \%$ sucrose layer, and the thylakoid membranes formed a green band at the interface between the 39 and $50 \%$ sucrose layers.

Cytosolic fractions were isolated from PG-supplemented and PG-depleted cells that were suspended in a buffer containing $50 \mathrm{mM}$ MES (pH 6.5), $2 \mathrm{mM}$-amino-caproic acid, 5 $\mathrm{mM}$ EDTA, $1 \mathrm{mM}$ PMSF and $1 \mathrm{mM}$ benzamidine. Cells were disrupted with $0.1 \mathrm{~mm}$ glass beads in a Bead Beater homogenizer. Intact cells, cell walls and all membranes were removed by ultracentrifugation $\left(45 \mathrm{~min}, 145,000 \times \mathrm{g}, 4^{\circ} \mathrm{C}\right.$ ). Pigments were extracted from lyophilized supernatants.

\subsection{Protein analyses}

$2 D-B N / S D S-P A G E$ - For the analysis of protein complexes, the isolated membranes were solubilized with dodecyl- $\beta$-D-maltoside $(\mathrm{DM} / \mathrm{Chl}=40: 1 \mathrm{w} / \mathrm{w})$ and analyzed by bluenative electrophoresis at $4{ }^{\circ} \mathrm{C}$ in a 5 to $14 \%$ polyacrylamide gel according to Schägger and 
coworkers (Schagger et al. 1994). Samples with $6 \mu \mathrm{g}$ Chl content were loaded onto the gel. The protein composition of the complexes was assessed by a $2^{\text {nd }}$ electrophoresis in a denaturing 12 to $20 \%$ linear gradient polyacrylamide gel containing $7 \mathrm{M}$ urea (Komenda et al. 2002). The lanes from the native gel were excised along their entire length, incubated for $30 \mathrm{~min}$ in $25 \mathrm{mM}$ Tris/ $\mathrm{HCl}, \mathrm{pH} 7.5$ containing $1 \%$ SDS (w/v) and placed on top of the denaturing gel. Proteins separated in the gel were stained by Coomassie Blue.

Western blot analysis of PSI and PSII large protein subunits - Samples containing $1 \mu \mathrm{g}$ Chl were loaded onto the denaturating gel (described above) and the separated proteins were transferred onto a PVDF membrane. Membranes were incubated with specific primary antibodies and then with a secondary antibody-horseradish peroxidase conjugate (Sigma, St. Louis, USA). The primary antibodies used in this study were raised in rabbits against: (i) residues 58 to 86 of the spinach D1 polypeptide, (ii) the last 12 residues of the D2 polypeptide from Synechocystis, (iii) residues 380 to 394 of barley CP47; (iv) the whole isolated CP43 from Synechocystis; and (v) the last 14 residues of the PsbI protein from Synechocystis.

For autoradiography, the gel or the membrane with labeled proteins was visualized on $\mathrm{X}$-ray films exposed at room temperature for 2 to 3 days or on Phosphorimager plates (GE Healthcarotenoide, Vienna, Austria) overnight. Quantitation of bands was done using ImageQuant 5.2 software (GE Healthcarotenoide, Vienna, Austria).

Western blot analysis of Cyt $b_{6}$ f large protein subunits-SDS-PAGE was performed according to the standard procedure (Schagger and von Jagow 1987), using 12\% gels. In each lane a sample containing $3 \mu \mathrm{g} \mathrm{Chl}$ was loaded. Proteins separated by SDS-PAGE were transferred to nitrocellulose membranes (Protran BA 85; Schleicher \& Schuell, Keene, NH) according to Towbin et al. (Towbin et al. 1979). Blots were probed with rabbit polyclonal antibodies raised against Cyt $b_{6} f$ protein subunits of Synechocystis (anti-Cyt $b_{6}$ and anti-Cyt f). Blots were developed by using goat anti-rabbit secondary antibodies conjugated with alkaline phosphatase according to the standard nitroblue tetrazolium/5-bromo-4-chloro-3indolyl phosphate staining protocol (Ausubel et al. 1995).

\subsection{Oxygen-evolving activity measurements}

Oxygen-evolving activity in whole cells was measured with a Clark-type oxygen electrode (Hansatech Instruments, Kings Lynn, U.K.) as described by Gombos and coworkers (Gombos et al. 2002). PSII oxygen-evolving activity was measured from $\mathrm{H}_{2} \mathrm{O}$ to 
parabenzoquinone (artificial acceptor), at a concentration of $500 \mu \mathrm{M}$. The cells were washed with BG11 medium and re-suspended in fresh BG11 medium for the measurement of oxygen evolution. An incandescent lamp equipped with a red optical filter was the light source. This arrangement was used for all the oxygen evolution measurements at a saturating light intensity of $500 \mu \mathrm{mol}$ photons $\mathrm{m}^{-2} \mathrm{~s}^{-1}$. The Chl concentration of the cells was adjusted to $5 \mu \mathrm{g}$ $\mathrm{ml}^{-1}$.

\subsection{Chlorophyll $a$ fluorescence measurements $(\mathrm{Fv} / \mathrm{Fm})$ and the changes in P700 signal (Pm-Po), and oxidation-reduction measurements of P700 kinetics}

Redox changes of P700 and Chl $a$ fluorescence were measured by a Dual-PAM-100 Measuring System (Heinz Walz GmbH, Germany) equipped with DUAL-E Measuring Head (difference of intensities of $830 \mathrm{~nm}$ and $875 \mathrm{~nm}$ ) with P700 Near Infra Red Emitter (720 nm) and DUAL-DR (red) Measuring Head $(620 \mathrm{~nm}$ ). The same amount of sample (equivalent to $20 \mu \mathrm{g}$ Chl concentration) was filtered onto a Whatman GF/C glass-fiber disc. Three independent repetitions were made for each type of measurement.

Maximum PSII yield, $(F v / F m)$ was determined after 20 min dark-adaptation to allow relaxation of the photosynthetic electron transport and determination of the fluorescence yield of open PSII RCs (Fo). Maximal fluorescence yield of close PSII RCs in dark adaptate state (Fm) is detected during a $2000 \mu \mathrm{mol}$ photons $\mathrm{m}^{-2} \mathrm{~s}^{-1}$ saturation pulse. Using these parameters, the following ratios were calculated. Fv (Fm-Fo), variable fluorescence, indicates the maximum fluorescence change in dark-adapted cells. $\mathrm{Fv} / \mathrm{Fm}=(\mathrm{Fm}-\mathrm{Fo}) / \mathrm{Fm}$ is a sensitive indicator of maximum photosynthetic efficiency of PSII in the dark-adapted state.

Maximum changes of P700 signals (Pm-Po) were determined after 20 min dark adaptation that allows reduction of P700 $\left(\mathrm{P}_{0}\right)$. Then, P700 was oxidized by far red light preillumination for 10 seconds and then maximum signal level was induced by $20000 \mu \mathrm{mol}$ photons $\mathrm{m}^{-2} \mathrm{~s}^{-1}$ actinic red light in the presence of far red light. Maximum changes of P700 signal levels between P700 fully reduced $\left(\mathrm{P}_{0}\right)$ and P700 fully oxidized $(\mathrm{Pm})$ were recorded on a millisecond time scale.

Oxidation-Reduction Kinetics of P700 was determined by $53 \mu \mathrm{mol}$ photons $\mathrm{m}^{-2} \mathrm{~s}^{-1}$ continuous actinic red light illumination after $20 \mathrm{~min}$ dark adaptation at room temperature. P700 absorbance changes were recorded on a millisecond time scale. Linear electron transport was inhibited by the addition of $100 \mu \mathrm{M}$ 3-(3,4-dichlorophenyl)-1,1-dimethylurea (DCMU). 


\subsection{RESULTS}

\subsection{Generation of carotenoid-less $\Delta c r t H / B$ strain in Synechocystis}

For the generation of the carotenoid deficient mutant, partial carotenoid deficient $\Delta c r t H$ cells were used as a host strain. $\Delta c r t H$ cells grown in dark contain only $c i s$-lycopenes and a small amount of all-trans-carotenes. On the other hand, in light conditions the $\mathrm{crtH}$ gene, encoding cis to trans carotene isomerase, can be activated by photoisomerization and $\Delta c r t H$ cells contain all carotenoids typical for WT (Masamoto et al. 2001). Their adaptation to partial carotenoid deficiency and dark-grown conditions could increase the probability of successful survival of the carotenoid-less mutant. Phytoene synthase encoded by the gene $\operatorname{crtB}$ catalyses the first synthetic reaction of carotenoid biosynthesis. It produces 15-cisphytoene. The fully segregated, carotenoid-less mutant cells lacking the $\operatorname{crt} B$ gene were obtained by transformation of the $\Delta c r t H$ mutant (Fig 6).

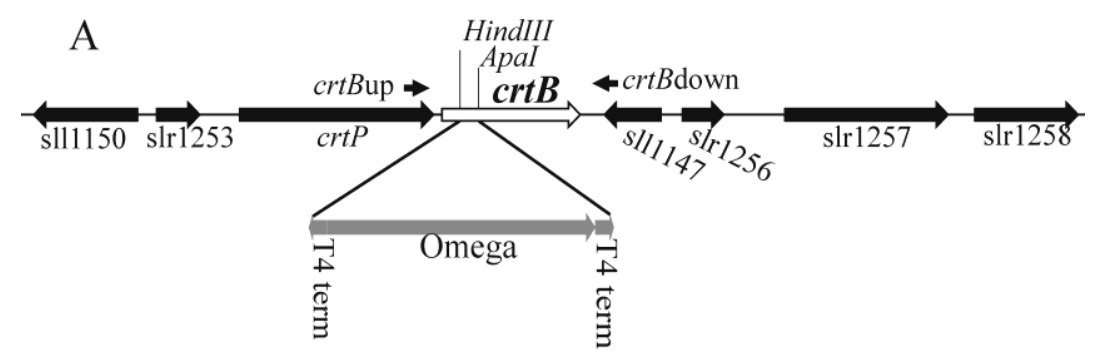

B

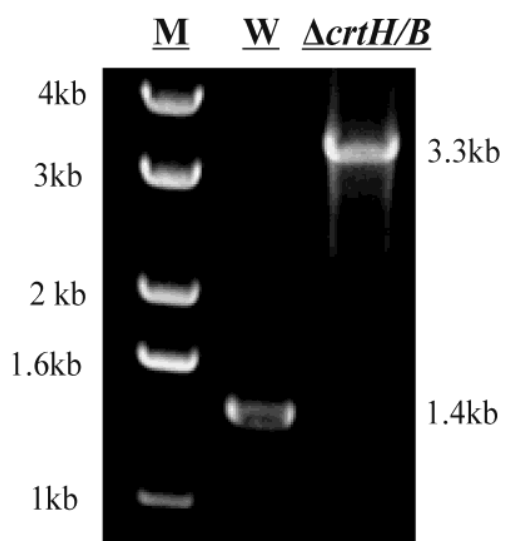

\section{Figure 10: Genetic inactivation of $\mathrm{crtB}$}

(A) Physical map of the Synechocystis genome fragment containing $\operatorname{crtB}$. In the inactivated strain the omega cassette replaces a 140-bp-long ApaI-HindIII fragment. Black arrows indicate position of PCR primers used for checking the complete segregation. (B) PCR analysis of WT and $\Delta c r t H / B$ transformants. Sizes of the fragments containing WT and mutant allele are indicated on the right and size marker (M) on the left. 
Transformation was performed by insertion of an omega cassette that provides spectinomycin resistance (Fig. 10A) as a selection marker. Complete segregation of the $\Delta c r t H / B$ mutant (Fig. 10B) could be carried out only under light-activated heterotrophic growth (LAHG) conditions. In LAHG conditions cells are grown in the presence of 5-10 mM glucose in the dark with brief, 5-10 min daily illumination (Anderson and McIntosh 1991).

To prove the absence of carotenoids in the mutant, elution profiles of the extracted pigments of WT and $\Delta c r t H / B$ cells grown under LAHG conditions were compared by highperformance liquid chromatography (HPLC) (Fig. 11). The peaks corresponding to carotenoid and Chl $a$ were identified according to both their absorption spectra and retention times (Fig. 11A). WT cells contained myxoxanthophyll, zeaxanthin, echinenone, $\beta$-carotene and Chl $a$, while in cells of $\Delta c r t H / B$ only Chl $a$ was found, neither carotenoids nor any of their intermediates were detectable (Fig. 11B). The same results were obtained with cells illuminated for 24 hours (data not shown).
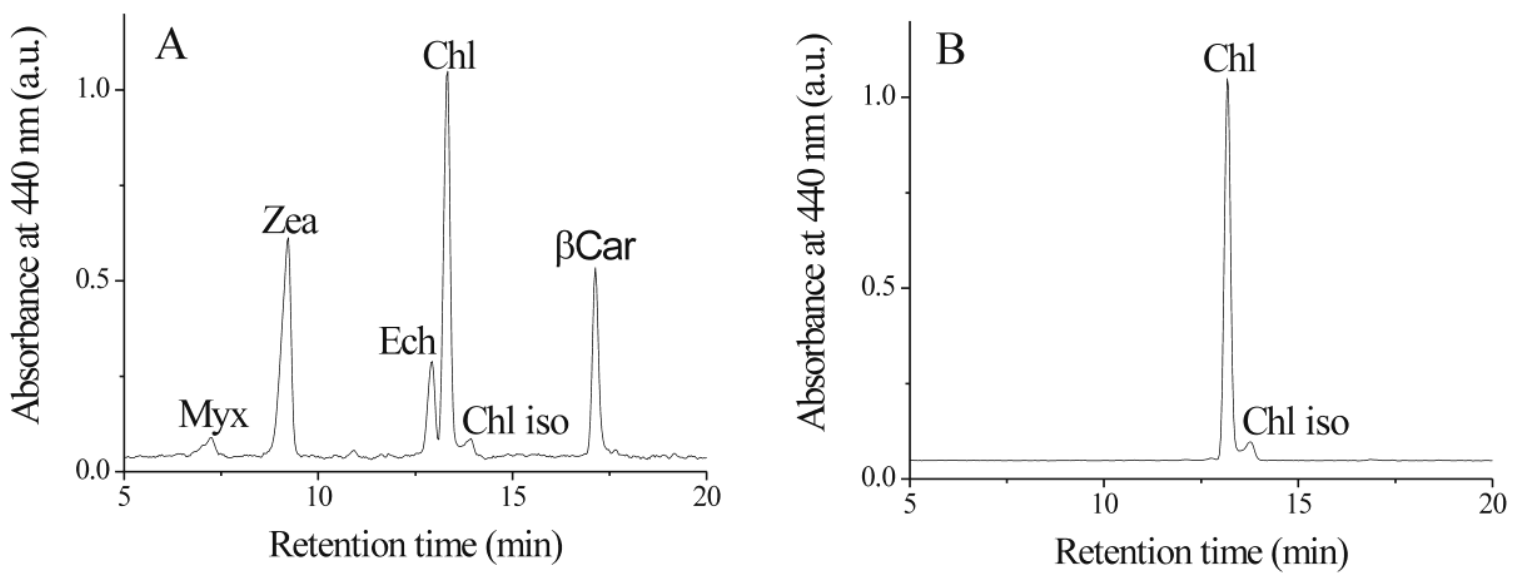

Figure 11: Pigment analysis by of WT (A) and $\Delta c r t H / B$ (B) cells by high-performance liquid chromatography

The cells were grown under LAHG conditions. The HPLC chromatograms were recorded at $440 \mathrm{~nm}$. Carotenoid derivatives were identified on the basis of both their absorption spectra and their retention times. Abbreviations: $\beta$-Car, $\beta$-carotene; Myx, myxoxanthophyll; Zea, zeaxanthin; Ech, echinenone; Chl, chlorophyll and $\mathrm{Chl}$ iso, chlorophyll isomers.

\subsection{Physiological consequences of the carotenoid deficiency}

\subsubsection{Growth rate and light sensitivity}

The growth rate of $\Delta c r t H$ and $\Delta c r t H / B$ cells was similar to that of WT cells under LAHG conditions. In 3 days the cell density of all strains gradually increased from 0.2 to 0.8 - 
0.9 (optical density recorded at $730 \mathrm{~nm}, \mathrm{OD}_{730}$ ) under LAHG conditions (Fig. 12). Following 3 days of culturing the cells were exposed to a light intensity of $35 \mu \mathrm{mol}$ photons $\mathrm{m}^{-2} \mathrm{~s}^{-1}$. WT and $\Delta c r t H$ cells adapted to light and kept growing. Under LAHG and photomixotrophic growth conditions $\Delta c r t H$ and WT cells gave similar growth profiles indicating that disruption of the $c r t H$ gene had no serious effect on growth (Masamoto et al. 2001). In contrast, the $\Delta c r t H / B$ cells stopped growing and the cells bleached and died.

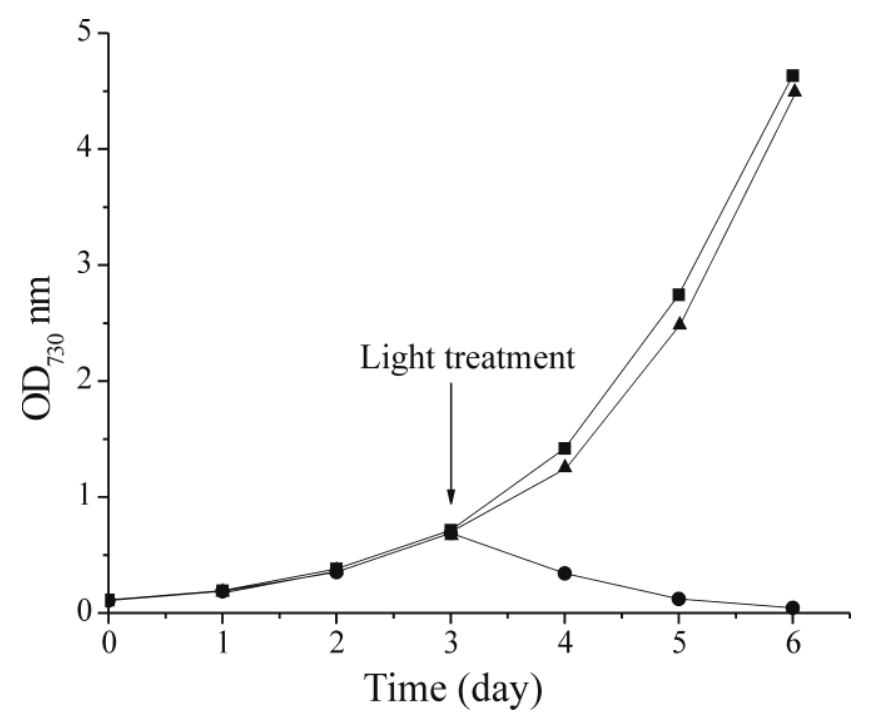

Figure 12: Growth curve of Synechocystis WT, $\Delta c r t H$ and $\Delta c r t H / B$ cells

WT (squares), $\Delta c r t H$ (triangles) and $\Delta c r t H / B$ (circles) cells grown at $30{ }^{\circ} \mathrm{C}$ under LAHG conditions for 3 days and then illuminated at $35 \mu \mathrm{mol}$ photons $\mathrm{m}^{-2} \mathrm{~s}^{-1}$. Data derived from a representative experiment are shown.

WT and $\Delta c r t H$ cells have typical green coloration both under LAHG and light conditions (Fig. 13A, 13B). However, $\Delta c r t H / B$ cells grown under LAHG conditions had bluish color, indicating the presence of phycobiliproteins and suppression of Chls (Fig. 13A). Following a short-term light treatment at $35 \mu \mathrm{mol}$ photons $\mathrm{m}^{-2} \mathrm{~s}^{-1}$ the $\Delta c r t H / B$ cells were photo-bleached (Fig. 13B). These results suggested that the carotenoid-less mutant is extremely light sensitive. 


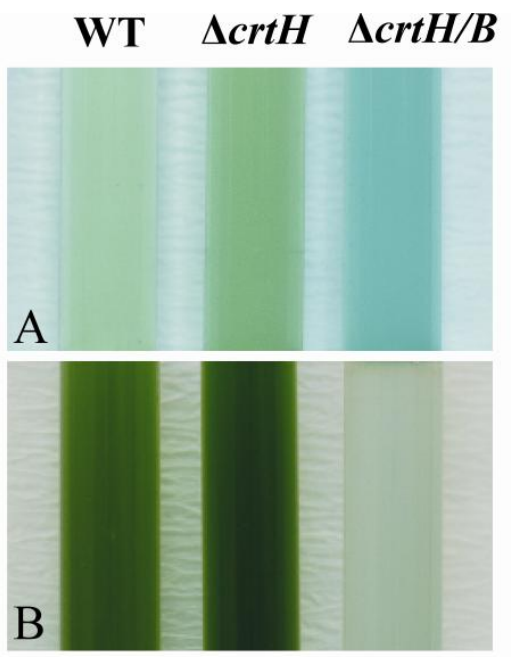

Figure 13: Effect of light on the pigmentation of $\mathrm{WT}, \Delta c r t H$ and $\Delta c r t H / B$ cells.

(A): Synechocystis WT, $\Delta c r t H$ and $\Delta c r t H / B$ cells grown at $30^{\circ} \mathrm{C}$ at the end of $3^{\text {rd }}$ day under LAHG conditions. (B): Synechocystis WT, $\Delta c r t H$ and $\Delta c r t H / B$ cells after a 48 hour light treatment at $35 \mu \mathrm{mol}$ photons $\mathrm{m}^{-2} \mathrm{~s}^{-1}$.

\subsubsection{Spectroscopic properties}

Absorption spectra of Synechocystis WT cells taken at room temperature showed four distinct regions. The absorption range between 435 and $450 \mathrm{~nm}$ corresponds to Sorret region of Chl $a$. The absorption ranges of 400 to $550 \mathrm{~nm}, 550$ to $650 \mathrm{~nm}$ and 650 to $700 \mathrm{~nm}$ belong to visible regions of carotenoids, phycobiliproteins and Chl $a$, respectively (Fig. 14). In the absorption spectra of the $\Delta c r t H / B$ cells there was a sharp decrease of absorption in the 450 to $550 \mathrm{~nm}$ region corresponding to carotenoids, confirming the complete absence of carotenoids in the cells (Fig. 14, red arrow). Furthermore, $\triangle c r t H / B$ cells exhibited a decrease in absorption with a shoulder at around 435 and $680 \mathrm{~nm}$ corresponding to Chl $a$ (Fig. 14, navyblue arrows). One-hour high light treatment at $500 \mu \mathrm{mol}$ photons $\mathrm{m}^{-2} \mathrm{~s}^{-1}$ had no effect on the Chl $a$ absorption profile of the WT cells (Fig. 14A dashed line). However, Chl $a$ content of $\Delta c r t H / B$ cells significantly decreased after one hour high light treatment (Fig. 14B solid line at around $680 \mathrm{~nm}$ ) compared to that of the cells grown under LAHG conditions (Fig. 14B dashed line at around 680). 


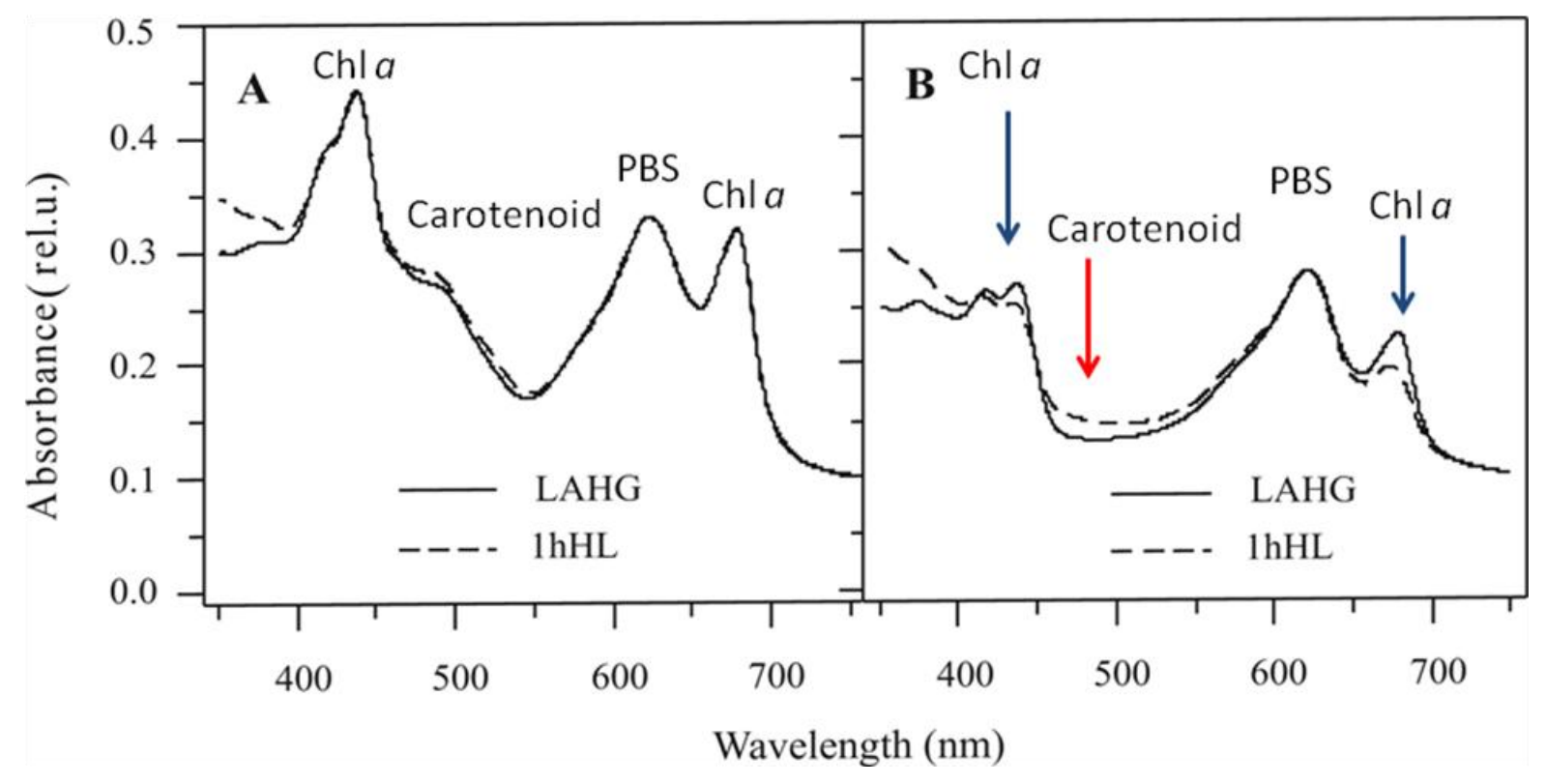

Figure 14: Absorption spectra of WT and $\triangle c r t H / B$ cells

(A) WT and (B) $\Delta c r t H / B$ cells grown under LAHG conditions (LAHG, solid line) and after one hour illumination at $500 \mu \mathrm{mol}$ photons $\mathrm{m}^{-2} \mathrm{~s}^{-1}$ white light (1hHL, dashed line). The spectra were taken at an identical absorbance of $750 \mathrm{~nm}$. Blue and red arrows indicate the changes in absorption bands of $\mathrm{Chl} a$ and carotenoid, respectively.

Low temperature Chl fluorescence emission spectra of WT and $\Delta c r t H / B$ cells $\left(\mathrm{OD}_{730}\right.$ $\sim 0.8$ ) were recorded. Chl $a$ was excited at $435 \mathrm{~nm}$. The emission spectrum of WT cells showed a minor band at around $685 \mathrm{~nm}$ that might correspond to PSII and a major band at $725 \mathrm{~nm}$, which corresponds to PSI-associated Chl $a$ (Fig. 15A). The fluorescence spectrum of $\Delta c r t H / B$ cells was distinctly different from that of WT cells. It showed three bands at 650 , at approximately 685 and at $723 \mathrm{~nm}$ (Fig. 15A). The latter is the highest peak corresponding to PSI-associated Chl $a$ and it is shifted by $2-3 \mathrm{~nm}$ to the blue region comparing with that of WT, most probably as a consequence of missing carotenoids. The peak at $650 \mathrm{~nm}$ is emitted by phycocyanin (MacColl and Guard-Friar 1987) and the peak at around $685 \mathrm{~nm}$ is emitted either by PSII-associated Chl $a$ or by APC-B and APC-L $\mathrm{L}_{\mathrm{CM}}$ (Rakhimberdieva et al. 2010), terminal emitters of PBSs. These two increased fluorescence emission peaks suggested that the linear electron transfer between PBS and PSI could not function efficiently. During thylakoid isolation process, PBSs are easily detached from the membrane. To distinguish between PBS-specific and Chl-specific fluorescence properties, emission spectra of isolated and well washed thylakoid membranes from WT and $\Delta c r t H / B$ cells were measured (Fig. 15B). Majority of the large fluorescence emission peaks at 650 and at around $685 \mathrm{~nm}$ was suppressed in the spectra of the thylakoid membranes of $\Delta c r t H / B$ cells, indicating that these 
bands were related to PBS terminal emitters emitting at $683 \mathrm{~nm}$ at $77 \mathrm{~K}$ (Rakhimberdieva et al. 2010).

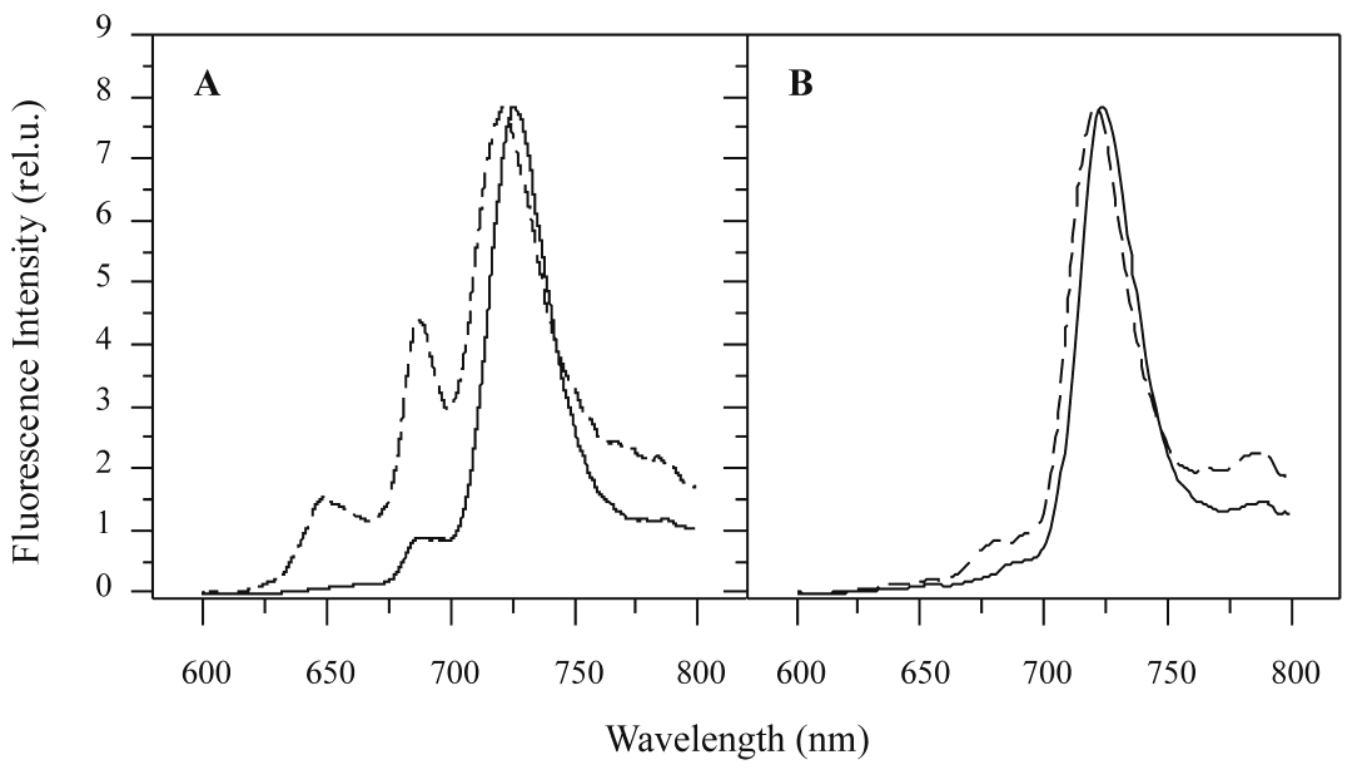

Figure 15: Low-temperature (77 K) fluorescence emission spectra of WT and $\Delta c r t H / B$ cells

(A) Whole cells and isolated thylakoid membranes (B) of WT (solid lines) and $\Delta c r t H / B$ (dashed lines) cells cultured under LAHG conditions. The excitation wavelength was $430 \mathrm{~nm}$. The spectra were recorded at $77 \mathrm{~K}$, corrected for the sensitivity of the photomultiplier and normalized to long wavelength maxima.

\subsection{Structural consequences of carotenoid deficiency}

\subsubsection{Level of the large protein subunits of photosynthetic complexes}

The accumulation of PSII as well as PSI and Cyt $b_{6} f$ protein in carotenoid deficient $\Delta c r t H / B$ cells grown in LAHG conditions were investigated by semi-quantitative western blot analysis (Fig.16).The level of PSI antenna protein subunits, PsaA and PsaB and Cyt $b_{6} f$ protein subunits, Cyt $b_{6}$ and Cyt $f$ of the $\Delta c r t H / B$ cells were similar to that of WT (Fig. 16). On the contrary, the levels of PSII core complex protein subunits D1 and D2, in $\Delta c r t H / B$ were much lower in comparison with those in the WT. Antenna protein subunit CP47 was hardly detectable and CP43 was completely absent (Fig. 16). The effect of low light on the accumulation of PSII, Cyt $b_{6} f$ and PSI protein subunits was also investigated in WT and $\Delta c r t H / B$ cells. After an exposure to $50 \mu \mathrm{mol}$ photons $\mathrm{m}^{2} \mathrm{~s}^{-1}$ for an hour, a further decrease in the amount of PSII protein subunits, D1, D2 and CP47 was detected while the level of PSI and Cyt $b_{6} f$ protein subunits did not change significantly in the carotenoid deficient mutant (Fig. 16) (Lupinkova and Komenda 2004). 


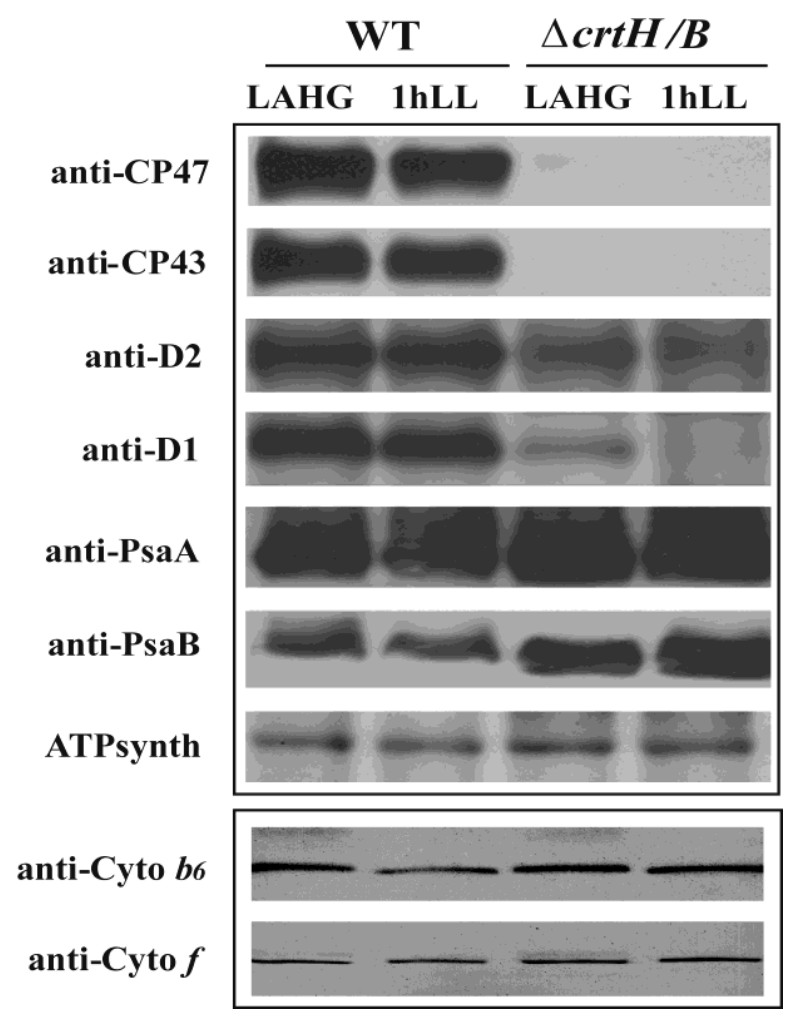

Figure 16: Western blot analysis of large protein subunits of photosynthetic complexes in $\mathrm{WT}$ and $\Delta \mathrm{crt} H / B$ cells

Cells were grown under LAHG conditions followed by 1 hour illumination at a light intensity of $50 \mu \mathrm{mol}$ photons $\mathrm{m}^{-2} \mathrm{~s}^{-1}$. One $\mu \mathrm{g}$ of $\mathrm{Chl}$ per lane was loaded onto the gel. Blots were incubated with specific antibodies and protein subunits of PSII and PSI were detected by peroxidase-conjugated secondary antibodies while Cyt $b_{6} f$ protein subunits by alkaline phosphatase-conjugated secondary antibodies. Stained bands of ATP synthase protein subunits are shown to document equal protein loading.

\subsubsection{Assembly of the photosynthetic complexes and their large protein subunits}

Accumulation of PSII subunit proteins were severely affected by the absence of carotenoids. Whereas, on the basis of the reason, which might be attributed either to the lack of the synthesis of protein subunits or to the lack of assembly..These effects were characterized in $\Delta c r t H / B$ cells by $2 \mathrm{D}$ gel electrophoresis. The first dimension was a blue native PAGE and denaturing PAGE was used as the second dimension (2D BN/SDS-PAGE). Protein levels were studied by autoradiography and immunoblotting. These techniques have recently been used for the characterization of the protein content of various Synechocystis mutants (Dobakova et al. 2007, Sobotka et al. 2008, Laczkó-Dobos et al. 2008). The protein complexes detected in WT cells grown under LAHG conditions were similar to those present 
in WT cells cultivated under photoheterotrophic growth conditions (Dobakova et al. 2007). Most of the PSI complexes existed in a trimeric form in WT cells and contribution of monomeric form did not exceed $30 \%$. In contrast to the WT cells, the monomeric PSI form was predominant in cells of $\Delta c r t H / B$ and it had a faster mobility (Komenda et al. 2004). About $90 \%$ of PSII protein subunits of WT cells accumulated in monomeric and dimeric forms and only a small amount of these protein subunits, less than 10\%, was present in RC47, intermediate PSII complex lacking CP43 (Komenda et al. 2004). In the carotenoid-less $\Delta c r t H / B$ cells both monomeric and dimeric PSII complexes were absent and only a negligible amount of RC47 was detected by Coomassie staining. Cyt $b_{6} f$ complexes were found exclusively in the form of monomeric complexes in WT. The level of the monomeric form of the Cyt $b_{6} f$ complex in the $\Delta c r t H / B$ was similar to that in the WT (Fig. 17, blue-native PAGE and Coomassie staining).

The labeling patterns of WT and $\Delta c r t H / B$ large protein subunits were shown on the autoradiogram of 2D gel electrophoresis (Fig. 17). The D1 was the most intensively labeled protein subunit in both strains. In WT cells, the D1 bands were present in both monomeric and dimeric PSII complexes and a small amount in RC47 while the majority of the D1 bands accumulated in mainly RC47 in the $\Delta c r t H / B$, and also in monomeric PSII complex and in $\mathrm{RCa}$ (Fig 17., 3 arrows). The RCa is an intermediate PSII complex lacking both inner antenna CP47 and CP43. It contains processed D1 as well as iD1, an incompletely processed precursor of D1 (Komenda et al. 2004). In contrast to typical labeling patterns of WT protein subunits, the majority of the $\Delta c r t H / B$ protein subunits were detected on the unassembled part (U.P), (Fig. 17). In addition, the overall labeling of the $\Delta c r t H / B$ proteins was 5-10 times less intensive than that of the WT proteins, Thus, in order to see the protein labeling of $\Delta c r t H / B$, the gel was exposed for five times longer period than that of WT. 


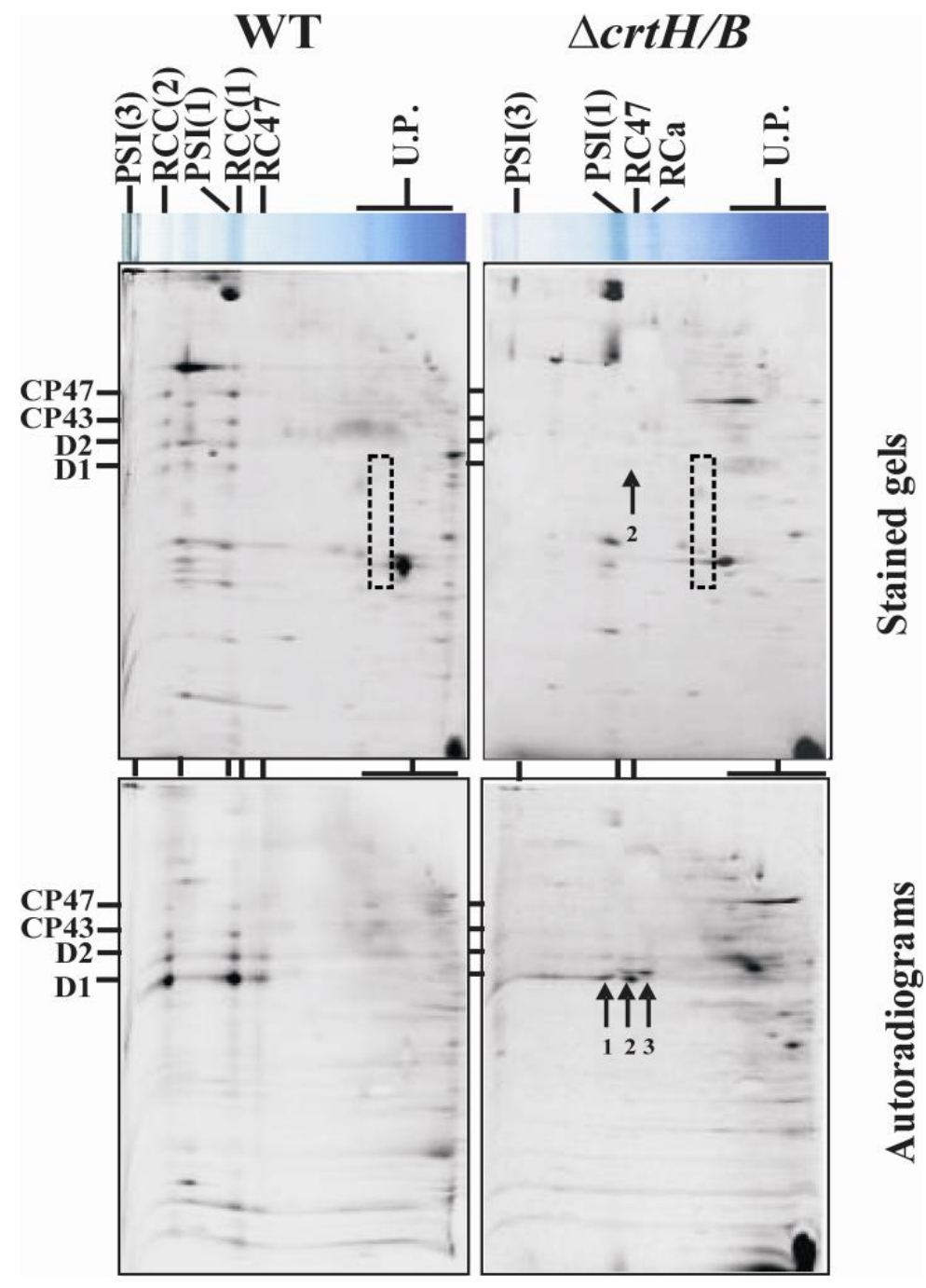

Figure 17: 2D-BN/SDS-PAGE of WT and $\Delta c r t H / B$ cells

Cells were grown under LAHG conditions and radioactively labeled with $\left[{ }^{35} \mathrm{~S}\right]$ Met and $\left[{ }^{35} \mathrm{~S}\right]$ Cys. The gels were stained by Coomassie Blue and exposed to Phosphorimager plates. Designation of complexes: PSI(3) and PSI(1), trimeric and monomeric PSI complexes, respectively; and RCC(2) and RCC(1), dimeric and monomeric PSII complexes, respectively. RC47 is an intermediate PSII complex lacking CP43, RCa is an intermediate PSII complex lacking both CP43 and CP47. U.P. indicates unassembled part. Boxes define positions of the large protein subunits of the monomeric Cyt $b_{6} f$ complex. Arrow 1, 2 and 3 designates D1 protein in RCC(1), RC47 and RCa complexes, respectively in the $\Delta c r t H / B$. Each sample contained $6 \mu \mathrm{g}$ of $\mathrm{Chl}$.

\subsubsection{Stabilization of the small protein subunits binding to the large protein subunits in photosystem II}

There are 13 low-mass small protein subunits with less than $10 \mathrm{kDa}$ in each monomer of PSII complex from T. elongatus (Guskov et al. 2009). It has been shown that small protein subunits can bind to the large protein subunits and many of them have been shown to have 
stabilization function in the PSII assembly (Promnares et al. 2006, Komenda et al. 2007, Dobakova et al. 2007, Muh et al. 2008). Analysis of the PSII complex demonstrated that all large protein subunits may exist in two forms with slower and faster electrophoretic mobilities (Komenda et al. 2004). The faster bands contain only the large protein subunits while the slower bands usually contain both large protein subunits together with binding small protein subunits. For instance, the slowly migrating native $\mathrm{pD} 1$ contains not only $\mathrm{pD} 1$ but also PsbI small protein subunit (Dobakova et al. 2007), or the slower migrating CP47 band contains not only CP47 but also PsbH small protein subunit, as well as Hlips or Scps (Promnares et al. 2006). Hlips (High Light Induced Proteins) or Scps (Small Cap-like Proteins), are single helix proteins with sequence similar to regions of the plant Chl $a / b$ binding proteins (CAB family proteins), and they are mostly induced under stress conditions such as high irradiance or low temperature (Funk and Vermaas 1999, He et al. 2001).

On the autoradiogram of 2D gel electrophoresis of $\Delta c r t H / B$, small amount of unassembled $\mathrm{CP} 43, \mathrm{CP} 47, \mathrm{D} 2$ and $\mathrm{pD} 1$, the D1 precursor, were detected (Fig. 17autoradiogram U.P. region and shown more detailed in Fig.19). To evaluate a possible effect of carotenoid deficiency on the binding of small protein subunits to large protein subunits in PSII, we compared the electrophoretic mobilities of unassembled forms of large protein subunits such as CP47, CP43 and D2 in the blue-native gel of the $\Delta c r t H / B$ with using two control strains; $\triangle Y C F 48$ and $\triangle P s b K$. The $\triangle Y C F 48$, which is an early PSII assembly mutant, accumulates large amounts of unassembled CP47, CP43 and D2 due to the low availability of D1 caused by the absence of the assembly factor YCF48 (Komenda et al. 2008). In the bluenative gel the majority of these unassembled large protein subunits migrated as the slower band (Fig. 18, designated without inverted comma - u.CP47, u.CP43 and u.D2). This indicated the presence of small subunit proteins bound to large unassembled large protein subunits in $\triangle Y C F 48$. On the other hand, the unassembled band of CP43 migrated as the faster band in the blue-native gel of $\triangle P s b K$ strain (Ikeuchi et al. 1991) (Fig. 18, designated with inverted comma, u.CP43') indicating that the slower band of unassembled CP43 of $\triangle Y C F 48$ contained at least PsbK small protein subunit (Fig.18). Interestingly, the faster band of unassembled CP43 also prevailed in $\Delta c r t H / B$ (Fig. 18), as well as that of the majority D2 and CP47 (Fig. 18, designated u.D2' and u.CP47', respectively). These indicated the absence of small protein subunits bound to large unassembled protein subunits in PSII complex of $\Delta c r t H / B$ in the absence of carotenoids. 


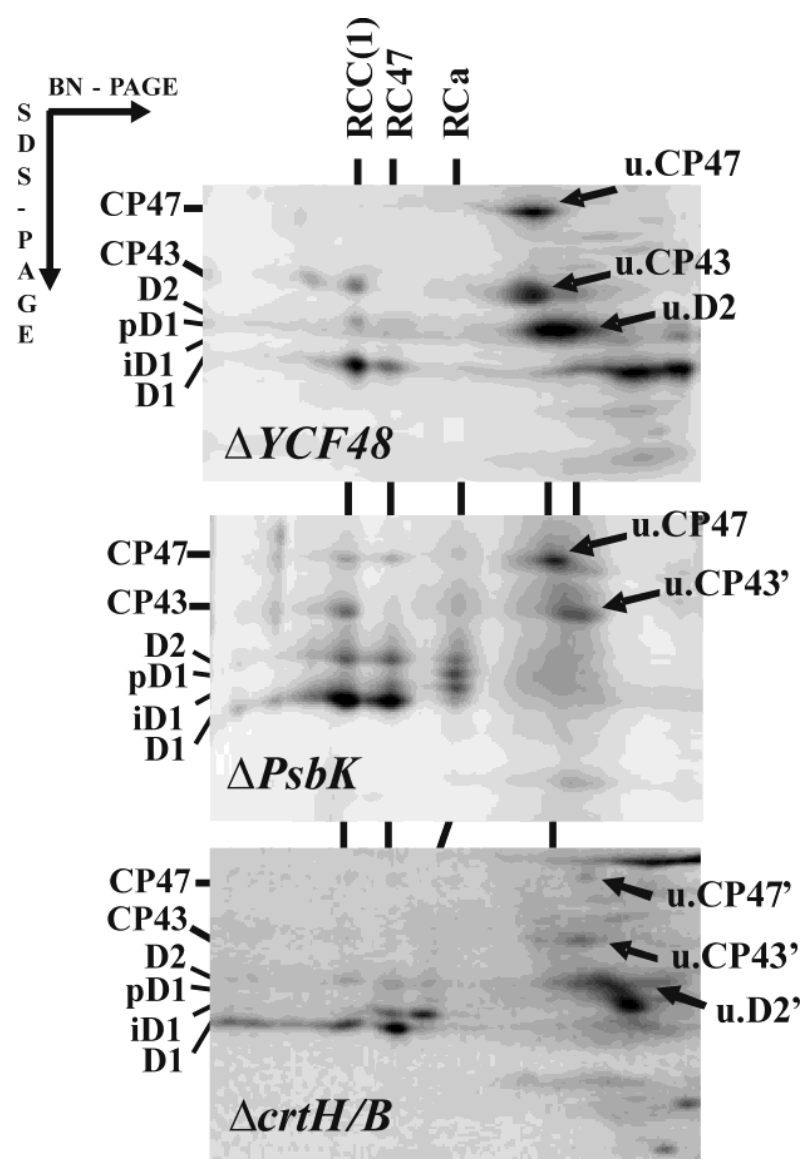

Figure 18: Autoradiogram of pulse-labeled membrane proteins of $\triangle Y C F 48, \triangle P s b K$ and $\Delta c r t H / B$ mutants separated by 2D-BN/SDS-PAGE

Six $\mu \mathrm{g}$ of $\mathrm{Chl}$ were loaded onto each gel. After separation the gels were stained, dried and exposed on PhosphorImager plates. Designation of the PSII complexes is the same as in Fig. 17. Moreover, pD1 indicates unprocessed D1 precursor and iD1 indicates incompletely processed D1 intermediate. The apostrophe designates unassembled proteins with unusually fast mobility in the BN gel most probably lacking bound small subunits.

\subsubsection{Assembly of the functional PSII core complex}

Taking into account the effect of carotenoid depletion on the migration of particular antenna protein subunits CP43 and CP47, we were interested in whether the absence of carotenoids also affected the assembly of PSII core complex protein subunits D1 and D2. Therefore, we chased the labeled proteins in the presence of chloramphenicol, a protein synthesis inhibitor, and followed their incorporation into complexes by 2D analysis (Fig. 19). Most of the unassembled D2 and pD1 (Fig. 17-pulse) disappeared with a concomitant increase in the labeling of D2 and D1 in RC47. This showed that they were efficiently inserted into the intermediate PSII complexes (Fig. 19-pulse-chase). This reflected partly the transformation of $\mathrm{RCa}$ into $\mathrm{RC} 47$, and partly the maturation of $\mathrm{iD} 1$ into $\mathrm{D} 1$, in the remaining 
RCa. The amount of weakly labeled protein subunits in monomeric PSII form also significantly decreased during the chase experiment. However, we could not detect any labeled protein subunits in the region of putative dimeric PSII form. This indicated that monomeric form was unstable and was rapidly converted into RC47, which was the main accumulated intermediate PSII complex as identified by Coomassie staining (Fig. 17) and immunoblotting (Fig. 19). Recently it was suggested that PsbI, a small protein subunit of PSII, stabilizes binding of CP43 into the PSII complex (Dobakova et al. 2007). According to X-ray crystallographic measurements, PsbI small protein subunit is bound to D1 in the vicinity of a $\beta$-carotene molecule (Loll et al. 2005b, Guskov et al. 2009). Immunodetection using specific antibodies confirmed the presence of PsbI in RC47 (Fig. 19-blot). Since, no increase in the level of unassembled CP43 was observed during the chase experiment we believe that the absence of $\beta$-carotene was the reason why CP43 is quickly detached from monomeric PSII complex and probably degraded. In $\Delta c r t H / B, \mathrm{RC} 47$ contained another small subunit protein PsbH (Fig. 19-blot), which stabilizes CP47 and facilitates its binding to the D1-D2 heterodimer (Komenda et al. 2002, Komenda et al. 2005). 


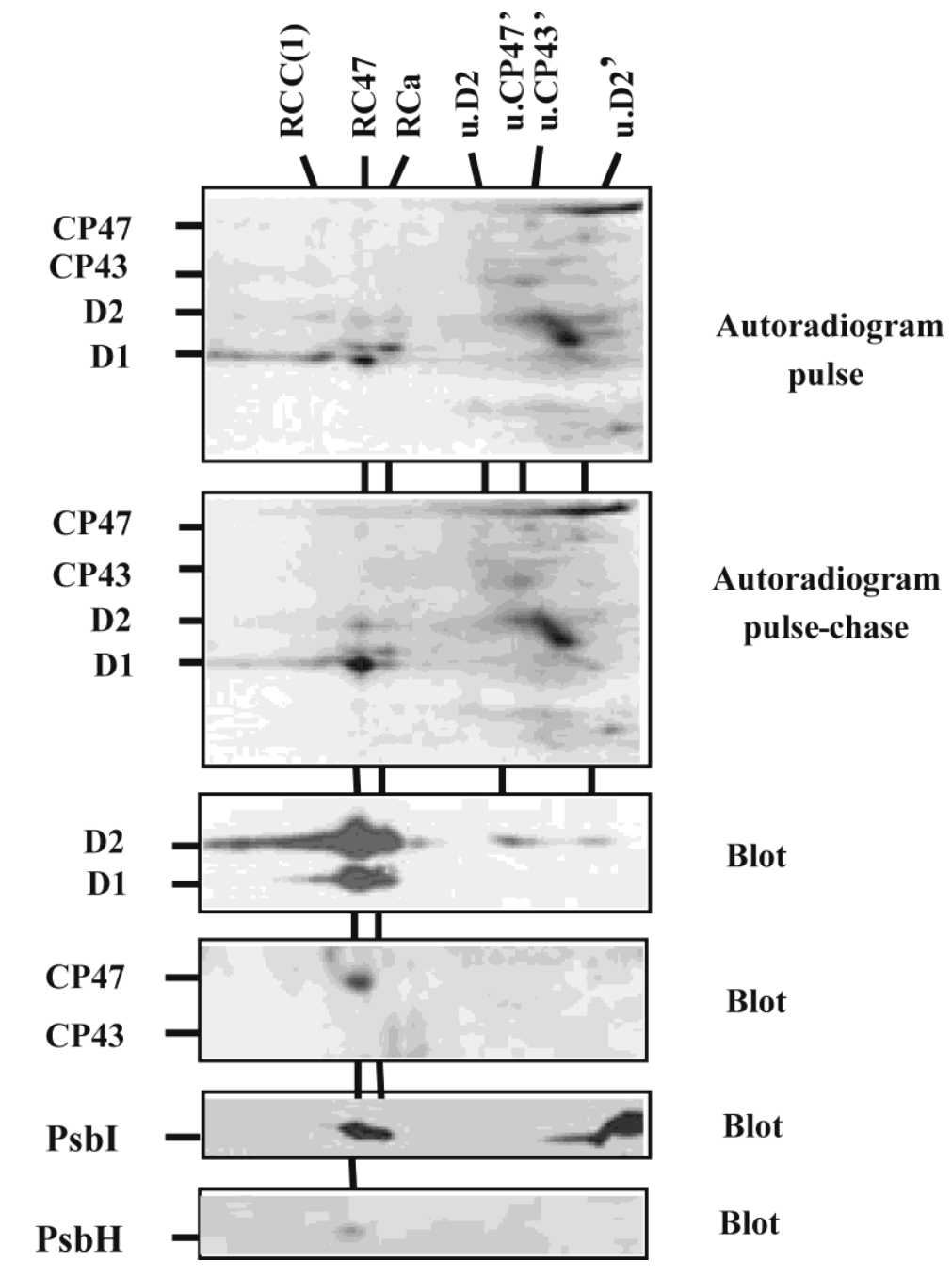

Figure 19: Autoradiogram and Western blot analysis of protein subunits of $\Delta c r t H / B$ cells separated by 2D-BN/SDS-PAGE

Cells of the $\Delta c r t H / B$ grown under LAHG conditions were labeled with $\left[{ }^{35} \mathrm{~S}\right]$ Met and $\left[{ }^{35} \mathrm{~S}\right]$ Cys (pulse experiment), then cold Met and cold Cys together with chloramphenicol were added and incubation continued (pulse-chase experiment) as described in Materials and Methods. Blot only for the pulse experiment is shown as it was identical to that of the pulsechase experiment. Designation of the PSII complexes is the same as in Fig. 17. The apostrophe designates unassembled proteins with unusually fast mobility in the BN gel. Each loaded sample contained $3 \mu \mathrm{g}$ of Chl.

\subsubsection{Level of genes encoding PSII large protein subunits}

Carotenoid deficiency seriously affected the accumulation of the major PSII proteins. However, it was not clear whether transcriptional levels of genes encoding these proteins were affected. To this end Northern blot analysis of WT and $\Delta c r t H / B$ cells grown under LAHG conditions was used. Steady-state levels of $p s b A, p s b B$, $p s b D I I$ and $p s b D I C$ gene transcripts encoding D1, CP47, D2 and D2 together with CP43 protein, respectively, were 
detected by gene specific probes. This analysis indicated that the transcription efficiencies of these genes were similar in WT and the $\Delta c r t H / B$ cells (Fig. 20).

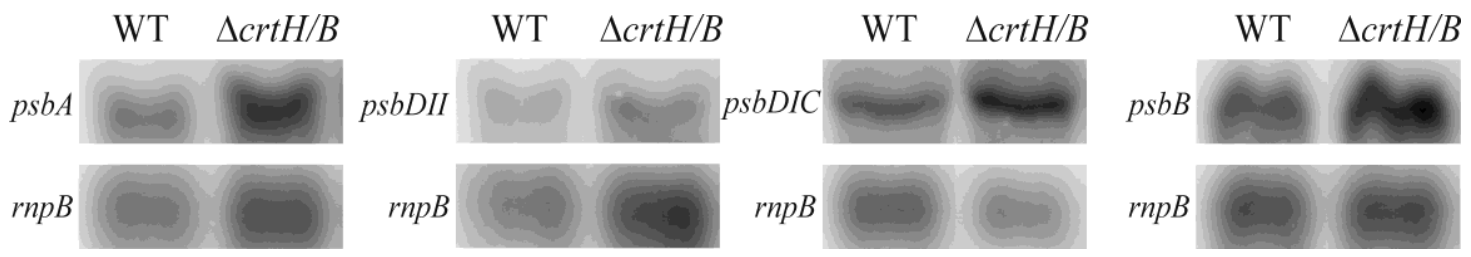

Figure 20: Northern hybridization analyses of genes encoding large protein subunits of PSII

$p s b A, p s b D I I, p s b D I C$ and $p s b B$ genes in WT and $\Delta c r t H / B$ grown under LAHG conditions. Ten $\mu \mathrm{g}$ of total RNA was loaded per lane. All membranes were probed also with the $r n p B$ (RNase P RNA gene) as a loading and transfer control.

\subsection{Functional consequences of carotenoid deficiency}

\subsubsection{Oxygen-evolving activity of the cells}

Oxygen-evolving activity from $\mathrm{H}_{2} \mathrm{O}$ to 1,4-parabenzoquinone, an artificial electron acceptor of PSII, was $220 \mu \mathrm{mol} \mathrm{O} \mathrm{mg} \mathrm{chl}^{-1} \mathrm{~h}^{-1}$ in WT cells grown under LAHG conditions. When the cells were transferred to the light at $35 \mu \mathrm{mol}$ photons $\mathrm{m}^{-2} \mathrm{~s}^{-1}$ light intensity, the activity increased from 220 to 260 and to $480 \mu \mathrm{mol} \mathrm{O}_{2} \mathrm{mg} \mathrm{chl}^{-1} \mathrm{~h}^{-1}$ in 3 and 48 hour, respectively. $\Delta c r t H$ cells showed no photosynthetic oxygen-evolving activity from $\mathrm{H}_{2} \mathrm{O}$ to 1,4parabenzoquinone, however they had active PSI related oxygen uptake (Masamoto et al. 2004) under LAHG conditions. After 48 hours of illumination, the oxygen evolving activity of $\Delta c r t H$ cells detected at $390 \mu \mathrm{mol} \mathrm{O}_{2} \mathrm{mg} \mathrm{chl}^{-1} \mathrm{~h}^{-1}$ which was similar to that of the WT cells indicating recovery of $\Delta c r t H$ cells upon illumination. In contrast, $\Delta c r t H / B$ cells showed no PSII activity measured from $\mathrm{H}_{2} \mathrm{O}$ to $\mathrm{CO}_{2}$ and from $\mathrm{H}_{2} \mathrm{O}$ to 1,4-parabenzoquinone either under LAHG conditions or after 3 or 48 hour of illumination.

\subsubsection{Maximum photosystem II efficiency in dark-adapted state (Fv/Fm)}

Measurements of Chl $a$ fluorescence on Synechocystis WT, $\Delta c r t H$ and $\Delta c r t H / B$ cells grown under LAHG conditions were performed following illumination at a light intensity of $35 \mu \mathrm{mol}$ photons $\mathrm{m}^{-2} \mathrm{~s}^{-1}$ for $0,2,10,24$ and 48 hours. Cell cultures were dark adapted for 20 min before each measurement to allow the determination of fluorescence intensity when all PSII RCs are open (Fo), i.e. they are capable of transferring electrons from the water 
oxidizing complex to the $\mathrm{Q}_{\mathrm{A}}$ electron acceptor before a saturation pulse applied to determine the maximum fluorescence intensity of closed PSII RCs (Fm). Based on these two parameters, the Fv/Fm parameter was calculated that is a sensitive indicator of photosynthetic efficiency in dark-adapted cells. WT, $\Delta c r t H$ and $\Delta c r t H / B$ cells grown under LAHG conditions showed no variable fluorescence (Fv) (Fig. 21A). PSII-recovery in both WT and $\Delta c r t H$ cells started within 2 hours of light treatment. The initial rapid increase in $\mathrm{Fv} / \mathrm{Fm}$ values of WT and $\Delta c r t H$ accounted within 24 hours which was nearly $70 \%$ of those in light grown forms. Fv/Fm values in WT and $\Delta c r t H$ cells grown in the light (at $35 \mu$ mol photons $\mathrm{m}^{-}$

${ }^{2} \mathrm{~s}^{-1}$ light intensity) were about 0.35 and 0.3 , respectively (Fig. 21A, $\infty$ ). In Synechocystis Fv/Fm values are rather low ( 0.3-0.4) (Ruengjitchatchawalya et al. 2005, Wilson et al. 2006) compared to those of higher plants. In contrast to the WT and $\Delta c r t H$ cells, in $\Delta c r t H / B$ cells no PSII activity was induced by illumination (Fig 21A).

\subsubsection{The maximum redox changes in P700 signals in dark-adapted state (Pm-Po)}

Measurement of the redox changes in P700 were performed in Synechocystis WT, $\Delta c r t H$ and $\Delta c r t H / B$ cells grown under LAHG conditions after light treatment for $0,2,10,24$ and 48 hours at $35 \mu \mathrm{mol}$ photons $\mathrm{m}^{-2} \mathrm{~s}^{-1}$. Cells were dark-adapted for $20 \mathrm{~min}$ before each measurement for maintaining the P700 in the reduced form (all RCs are open) to determine the minimum P700 signal level (Po). The changes in the level of active PSI centers were determined by applying a far-red pre-illumination for 10 seconds and the maximum P700 signal level (Pm) was induced by applying saturating light. The measurements demonstrated the presence of active P700 centers in carotenoid-less $\Delta c r t H / B$ under LAHG conditions. Exposure of cells for 24 hours to light significantly decreased PSI activity and almost no signal was detected after 48 hours of illumination (Fig. 21B). In Figure 21, it was demonstrated that in $\Delta c r t H / B$ cells there was neither PSII activity (Fig. 21A) nor PSI activity at the end of the light treatment (Fig 21B, 48 hours). Nevertheless, PSII-less mutant (psbDI, psbDII and psbC genes encoding D2 and CP43 proteins, respectively were blocked) having carotenoid but lacking PSII activity showed a constant PSI activity and typical green color even when the cells were grown in the light (Figure 22). These results indicate that carotenoid deficiency was the reason for the photoinhibition of PSI in $\Delta c r t H / B$. 

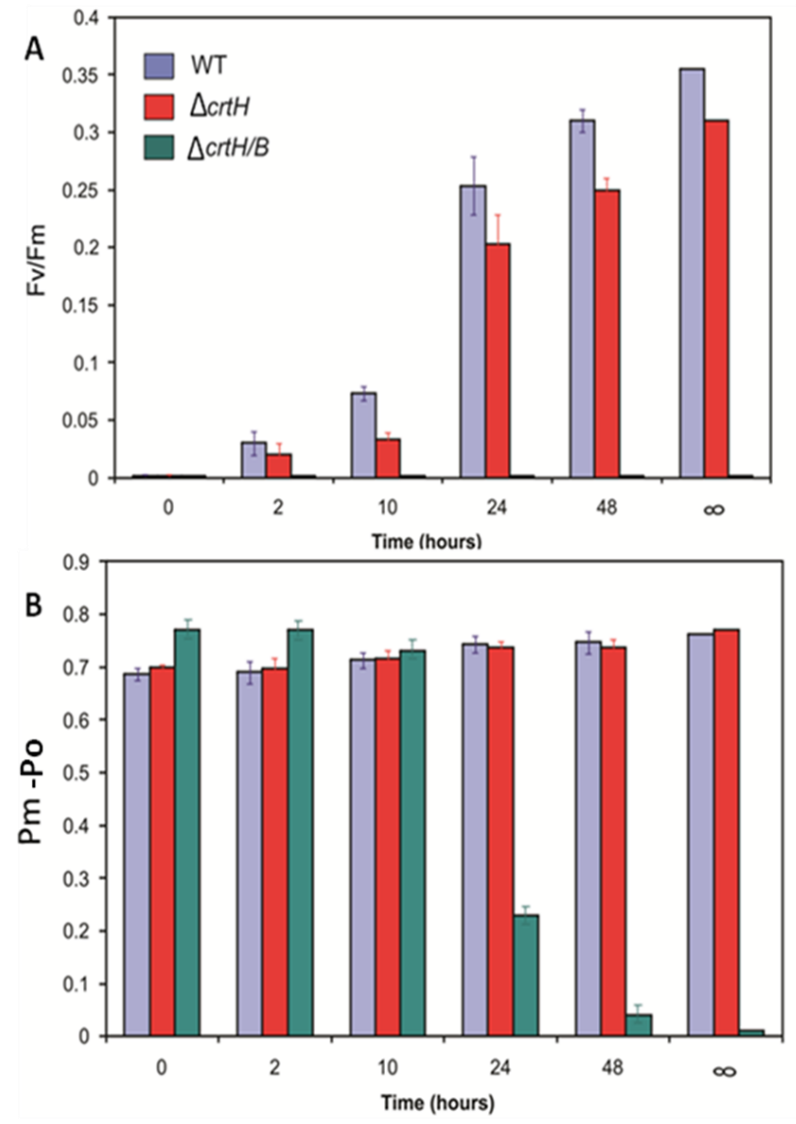

Figure 21: Photosynthetic activity of $\mathrm{WT}, \Delta c r t H$ and $\Delta c r t H / B$ cells

(A) Maximum PSII efficiency (Fv/Fm) and (B) Maximum changes in P700 signals (Pm-Po), were determined for WT, $\Delta c r t H$ and $\Delta c r t H / B$ under LAHG conditions after exposure to 35 $\mu$ mol photons $\mathrm{m}^{-2} \mathrm{~s}^{-1}$ light for $0,2,1024$ and 48 hours for both measurements. The data from three independent measurements were averaged. Blue; WT, red; $\Delta c r t H$, dark green; $\Delta c r t H / B$, 0 ; cells grown under LAHG conditions; $\infty$; cells grown under continuous light.
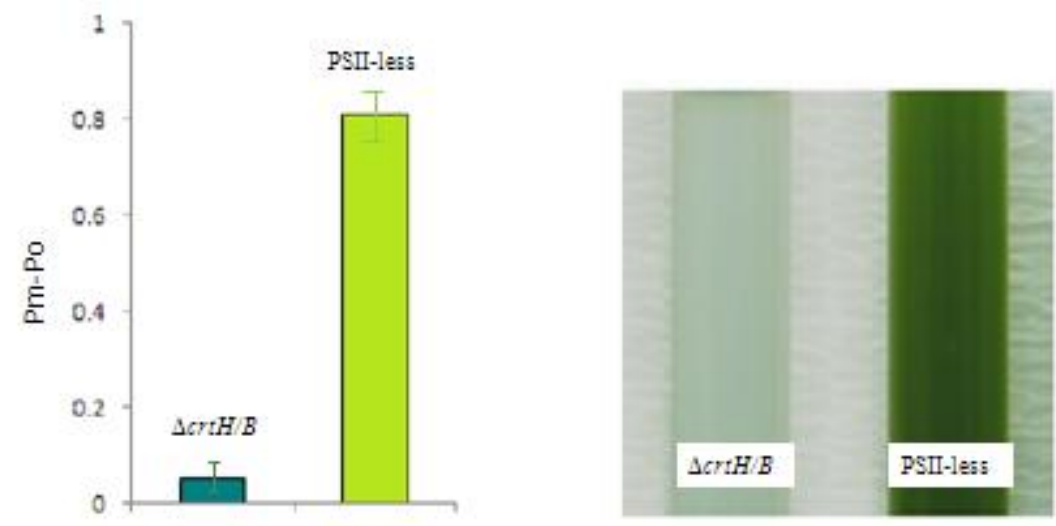

Figure 22: (A) The maximum changes in P700 signals for $\Delta c r t H / B$ and PSII-less mutants. (B) The effect of light on pigmentation of $\Delta c r t H / B$ and PSII-less mutants

$\Delta c r t H / B$ cells grown under LAHG conditions were collected after 48 hours at $35 \mu \mathrm{mol}$ photons $\mathrm{m}^{-2} \mathrm{~s}^{-1}$ light treatment and PSII-less cells grown in continuous light of $35 \mu \mathrm{mol}$ photons $\mathrm{m}^{-2} \mathrm{~s}^{-1}$. Delete the rest of the sentence. The data from three independent measurements were averaged. 


\subsubsection{Oxidation-reduction kinetics of P700}

Oxidation-reduction of P700 displays complex kinetics before it reaches the final steady-state level, as observed in several species of algae (Maxwell and Biggins 1977) and cyanobacteria (Ruengjitchatchawalya et al. 2005, Sas et al. 2006). In light grown WT cells, the main features of this oxidation kinetics can be described by a rapid initial decrease in the absorption (a) due to a fast photooxidation of P700 (b), followed by an almost complete, transient re-reduction (c), and then a second, slow oxidation to the final steady-state level (d). The transient reduction is caused by the electron flow from the reduced intersystem electron transport components, such as the plastoquinone (PQ) pool, the Cyt $b_{6} f$ complex, the plastocyanin, and the Cyt $c_{553}$. The slow oxidation of P700 reflects the depletion of this electron pool as a consequence of the rate-limiting step of $\mathrm{PQH}_{2}$ oxidation at the Cyt $b_{6} f$ complex. The dark reduction of $\mathrm{P} 700^{+}$(e) by intersystem electron transfer components after illumination follows first-order kinetics, in accordance with a single rate-limiting step between the two photosystems (Hartwig 2001). Figure 23A shows the P700 kinetics of WT cells in the absence and presence of $100 \mu \mathrm{M}$ DCMU. DCMU blocks $\mathrm{Q}_{\mathrm{A}}$ to $\mathrm{Q}_{\mathrm{B}}$ electron transfer and inhibits the transient reduction of $\mathrm{P} 700$ by preventing linear electron flow towards PSI..

The oxidation-reduction kinetics of P700 was measured for dark-adapted WT, $\Delta c r t H$ and $\Delta c r t H / B$ cells grown under LAHG conditions and following $0,2,10,24$ and 48 hours of light treatment at $35 \mu \mathrm{mol}$ photons $\mathrm{m}^{-2} \mathrm{~s}^{-1}$. The cells were dark-adapted for $20 \mathrm{~min}$ and then measured. In WT, $\Delta c r t H$ and $\Delta c r t H / B$ cells grown under LAHG conditions the extent of absorbance changes (Fig 23B, black lines) were similar to that of WT cells grown in light in the presence of DCMU (Fig 23A) indicating that there is no transient reduction of P700 by electrons originating from PSII in any of the strains under LAHG conditions. The oxidation kinetics of P700 in the dark-adapted $\Delta c r t H$ is similar to that of the WT. In both strains, transient reduction can be observed after $2 \mathrm{~h}$ of illumination. The transient reduction of P700 in $\Delta c r t H$ compared to that in WT was slightly delayed and its initial rate was slightly lower. Its final steady-state level, though, was almost the same after $48 \mathrm{~h}$ illumination. The oxidation of P700 in the $\Delta c r t H / B$ cells follows remarkably different kinetics. A transient reduction pattern was not observed in $\Delta c r t H / B$ cells after illumination. These data strongly suggest that, in contrast to PSII-recovery in WT and $\Delta c r t H$ cells exposed to light, in $\Delta c r t H / B$ the ratelimiting step was found at the donor side of P700 indicating absence of functional PSII (Fig. 23B). 
A

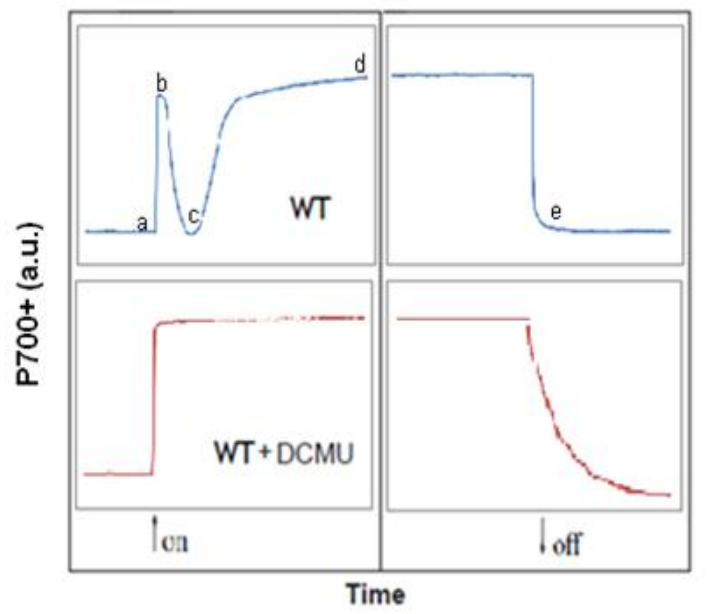

B

WT

$\Delta c r t H$

$\triangle c r t H / B$

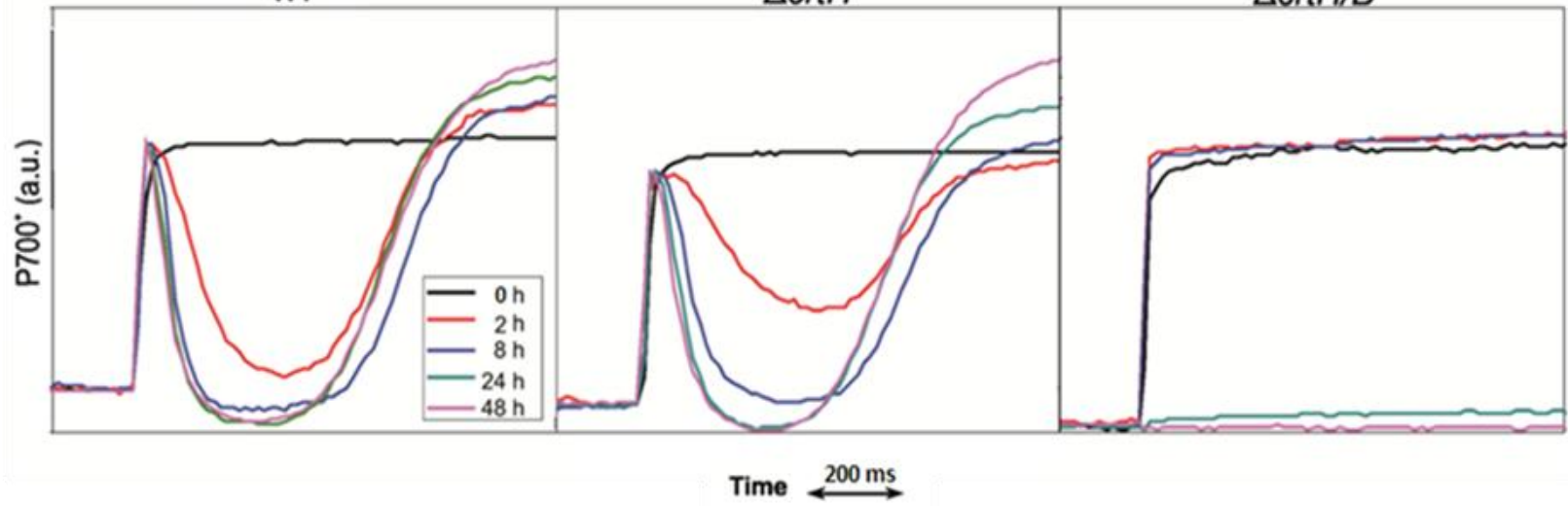

Figure 23: Oxidation-reduction kinetics of P700

(A) Typical oxidation-reduction kinetics in WT and WT $+100 \mu \mathrm{M}$ DCMU. a, b, c, d and e indicate the consecutive steps of oxidation-reduction kinetics. (B) Transient reduction kinetics of WT, $\Delta c r t H$ and $\Delta c r t H / B$ cells. The cells grown under LAHG conditions and after exposed to $50 \mu \mathrm{mol}$ photons $\mathrm{m}^{-2} \mathrm{~s}^{-1}$ light for 2, 1024 and 48 hours for both measurements. The data from 3 independent measurements were averaged. 


\subsection{Phosphatidylglycerol (PG) depletion induces an increase in myxoxanthophyll and echinenone biosynthetic activities in Synechocystis PCC 6803 cells}

In order to study the role of carotenoids in protection against other physiological stress we used a phosphatidylglycerol (PG)-deficient Synechocystis pgsA mutant (Hagio et al. 2000). We measured the changes in carotenoid content and composition during longer term PG depletion (Laczko-Dobos et al. 2008, Domonkos et al. 2009, Bogos et al. 2010). In order to analyze and localize the carotenoid accumulation in the PG-deficient mutant we isolated thylakoid and cytoplasmic membrane fractions either from PG-supplemented or from PGdepleted cells. The separation of cytoplasmic and thylakoid membrane layers by ultracentrifugation on a discontinuous sucrose density gradient revealed that the PG-depleted cells (-PG14day and -PG21day) contained higher amount of carotenoids than the PGsupplemented $(+\mathrm{PG})$ cells, especially in the upper part of the gradient which contained the water-soluble non-membrane fraction of the cells (Fig. 24).
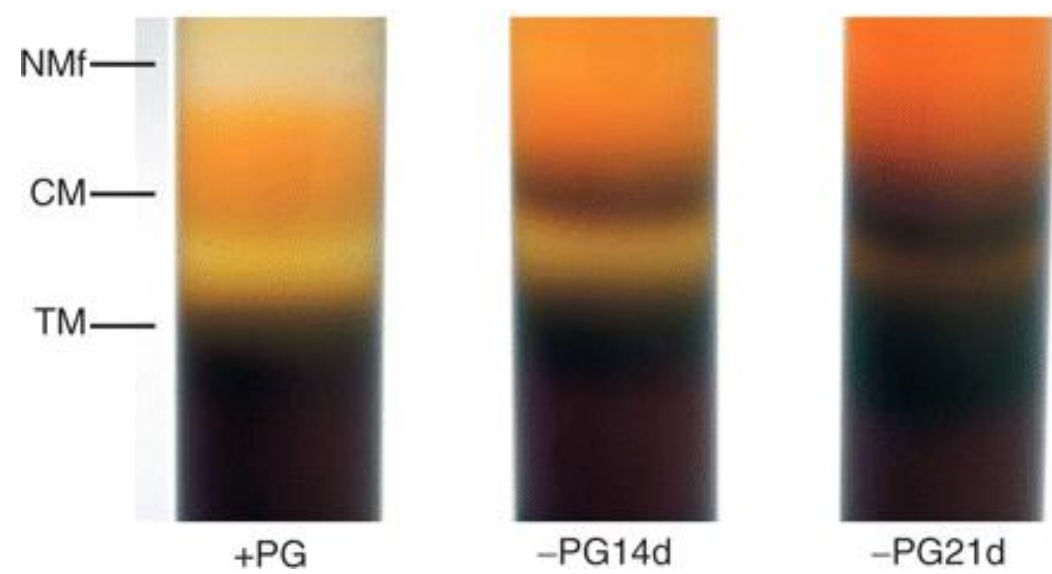

Figure 24: Accumulation of carotenoids induced by PG depletion

Isolation of thylakoid and cytoplasmic membranes from Synechocystis pgsA cells by sucrose gradient centrifugation. The loaded samples were normalized on the wet weight of the pelleted cells. + PG, PG-supplemented cells; -PG14d and -PG21d, PG-depleted cells on $14^{\text {th }}$ and $21^{\text {st }}$ days of growth, respectively; CM, cytoplasmic membrane; TM, thylakoid membrane; NMf, non-membrane fraction. 


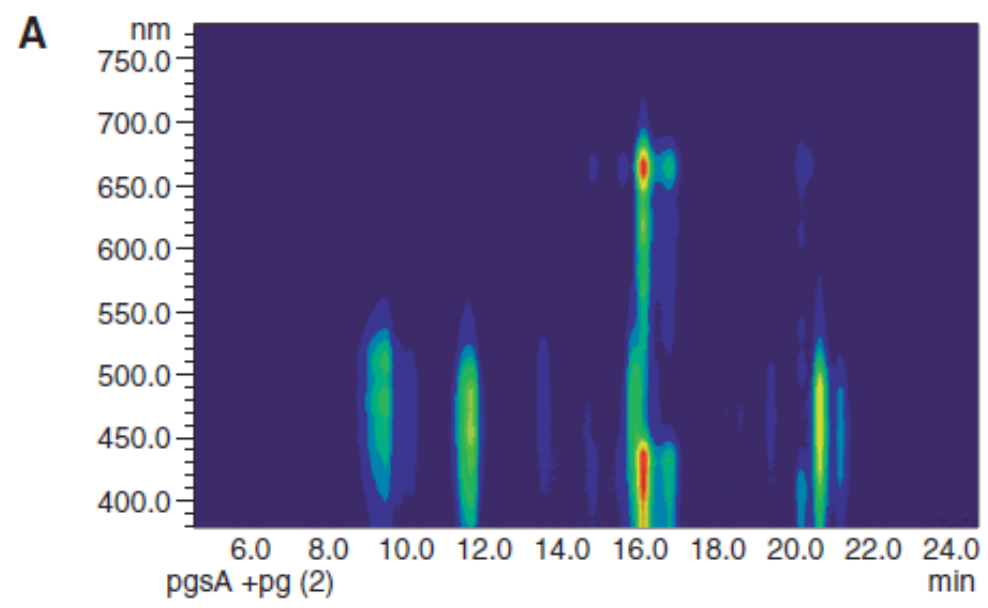

B
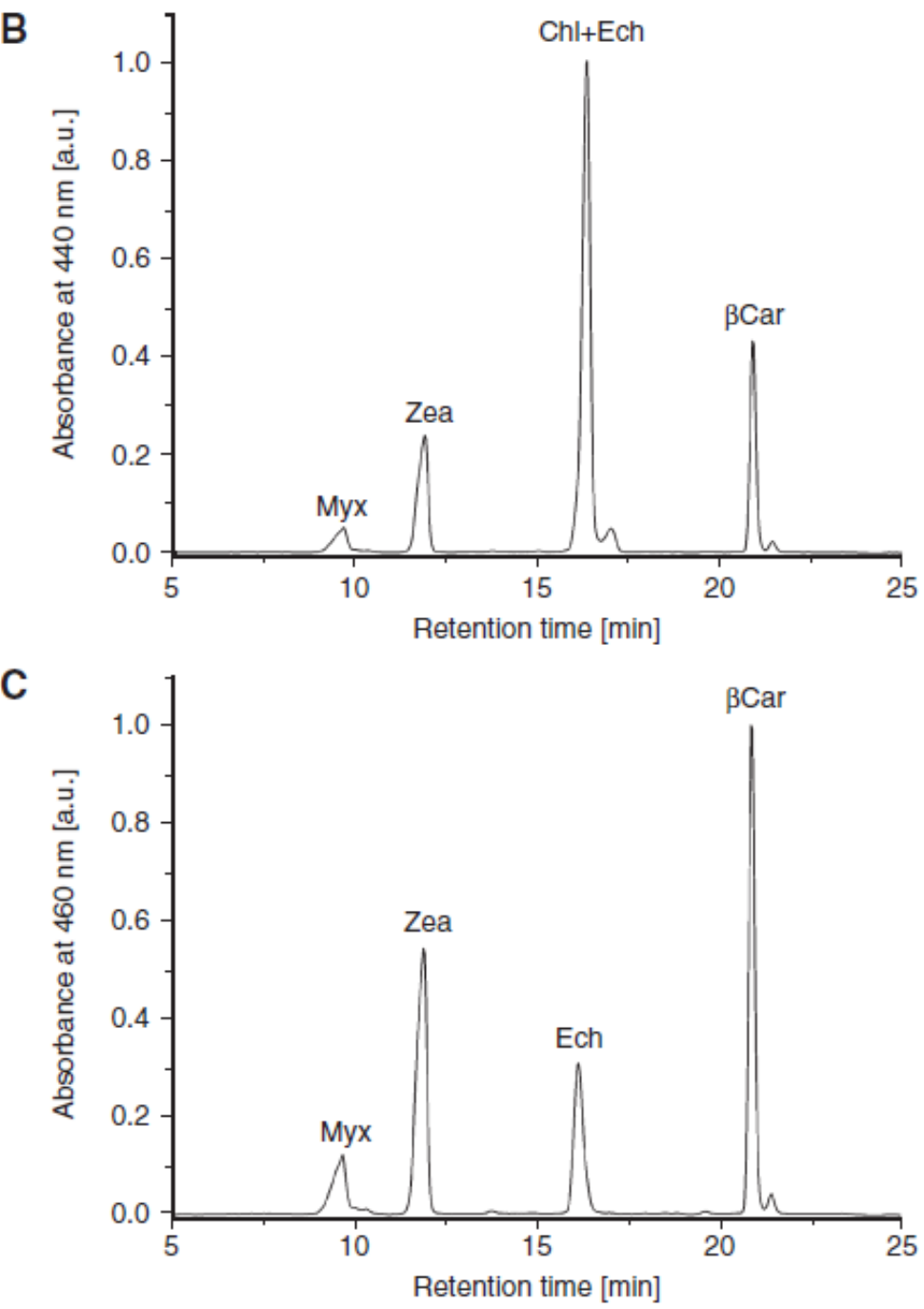

Figure 25: HPLC analysis of the pigment composition of Synechocystis pgsA cells

(A) 3D image of the chromatogram, (B) chromatogram recorded at $440 \mathrm{~nm}$, (C) chromatogram recorded at $460 \mathrm{~nm}$. myx, myxoxanthophyll; zea, zeaxanthin; ech, echinenone; $\beta$ car, $\beta$-carotene; Chl, chlorophyll. 

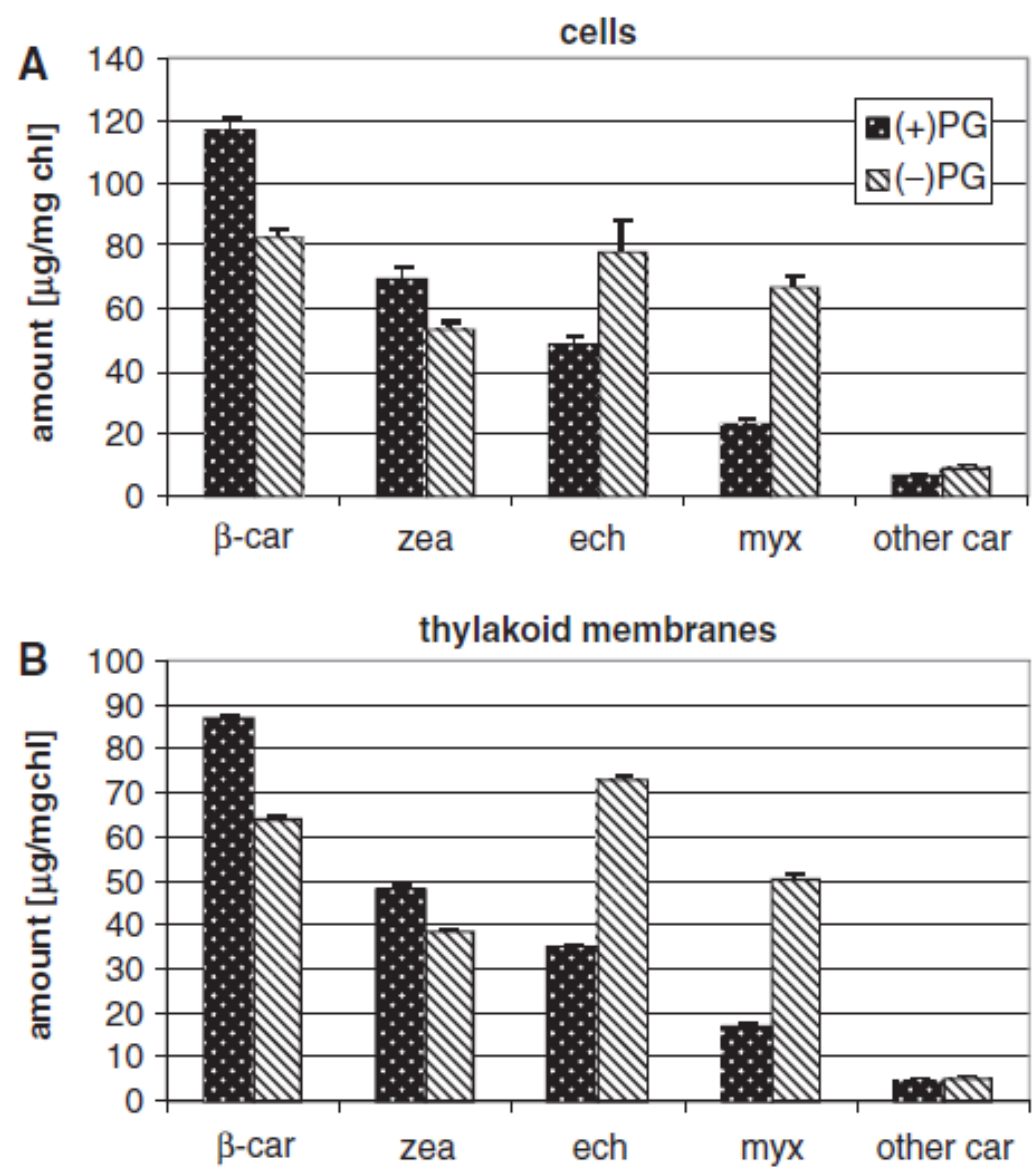

Figure 26: Changes in carotenoid content upon PG depletion

Amounts of carotenoid species relative to the Chl content (A) of whole cells and (B) of thylakoid membranes in PG-supplemented and PG-depleted pgsA cells. $+\mathrm{PG}$, cells grown in the presence of $\mathrm{PG} ;-\mathrm{PG}$, cells grown in the absence of $\mathrm{PG}$ for 21 days ; $\beta$-car, $\beta$-carotene; zea, zeaxanthin; ech, echinenone; myx, myxoxanthophyll; other car, unidentified carotene derivatives. Error bars represent $\pm \mathrm{SD}(n=3)$.

We analyzed the carotenoid species extracted from pgsA cells and from isolated membrane fractions by HPLC (Fig 25). In pgsA cells, myxoxanthophyll, zeaxanthin, echinenone and $\beta$-carotene were identified on the basis of their absorption spectra and their retention times (Fig 25). Since the difference in retention times between Chl $a$ and echinenone was too small, the echinenone content was calculated from the absorbance at the maximum $(460 \mathrm{~nm})$ of its spectrum. The total amount of carotenoid species was calculated from the HPLC chromatogram on Chl basis in PG-supplemented and PG-depleted pgsA cells as well as in thylakoid membranes (Fig. 26). The amounts of $\beta$-carotene and zeaxanthin decreased in the PG-depleted samples compared to those of the PG-supplemented samples. The amount of myxoxanthophyll increased approximately 3-fold in all PG-depleted samples, and the amount of echinenone was twice as high in the PG-depleted thylakoid membranes 
and to a lesser extent in whole cells than in PG-supplemented cells. Relative amount of the individual carotenoid species was also estimated from their peak areas from the HPLC chromatograms. The proportion of myxoxanthophyll and echinenone in the carotenoids of PG-depleted whole cells, isolated membranes and cytosol proved to be higher than in the corresponding PG-supplemented controls (data not shown). 


\subsection{DISCUSSION}

5.1 Structural and functional consequences of the carotenoid deficiency studied by the Synechocystis $\Delta$ crtH/B cells

The structural and functional consequences of the complete lack of carotenoids were studied in a carotenoid-less mutant of the oxygenic photosynthetic organism, Synechocystis. The mutant was generated in $\Delta c r t H$ mutant cells by inactivation of the $c r t B$ gene encoding phytoene synthase, which is responsible for the first committed reaction toward carotenoid biosynthesis (Fig. 27).

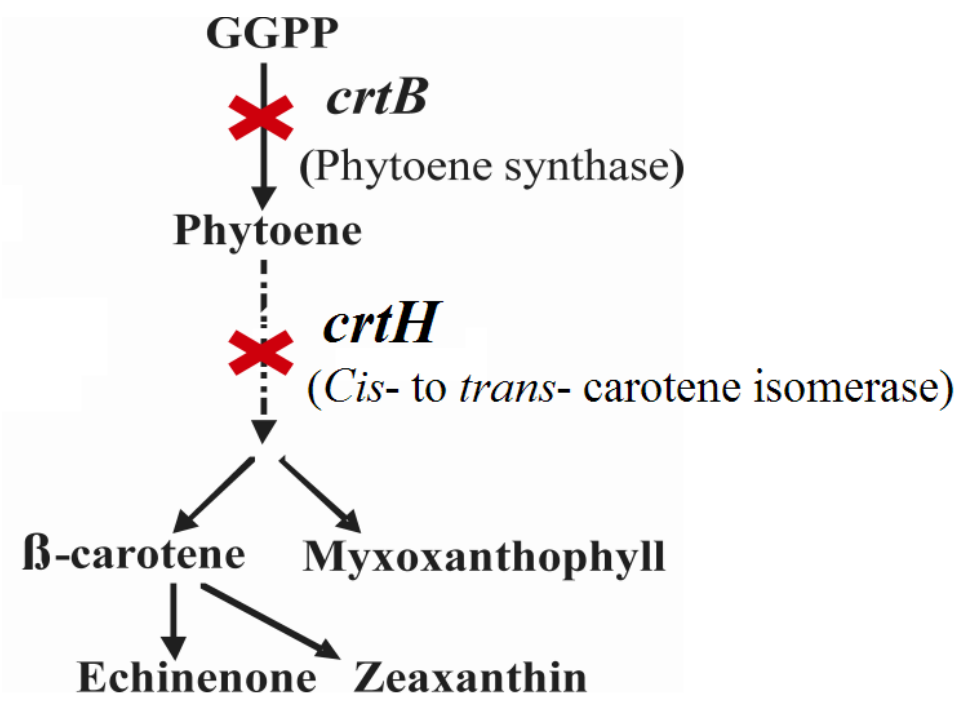

Figure 27: Inactivation of the $c r t B$ gene, encoding phytoene synthase, in $\Delta c r t H$ mutant in the carotenoid biosynthetic pathway in Synechocystis

$\Delta c r t H$ was used as a host strain for its better transformability compared to WT. Under photoautotrophic growth conditions carotenoid composition and growth rate of the $\Delta c r t H$ mutant cells were very similar to those of the WT (Breitenbach et al. 1998, Masamoto et al. 2001, Masamoto et al. 2004). Therefore, $\Delta c r t H$ was more suitable substitute than WT in construction of the carotenoid-less mutant $\Delta c r t H / B$. Under LAHG conditions complete segregation of the $\triangle c r t H / B$ mutant occurred and HPLC analysis demonstrated that the mutant cells contained no carotenoid derivatives (Fig. 11). The bluish color of the mutant cells indicated that phycobiliprotein synthesis and accumulation was not significantly suppressed, 
in contrast to chlorophyll synthesis and accumulation (Fig. 12). When the cells were exposed to light, the $\Delta c r t H / B$ cells gradually bleached and died (Fig. 12). This light susceptibility suggested that carotenoids are essential for the cells in the photoprotection mechanism.

As it was mentioned above, pigment availability is a major factor in the formation and function of photosynthetic complexes. In the monomeric PSII complex there are 12 carotenoid pigments identified in $T$. elongatus as $\beta$-carotene in all-trans configuration (Guskov 2009). Previously it has been suggested that $\beta$-carotene is vital for synthesis of D1 protein in the green alga, Chlamydomonas reinhardtii (Trebst and Depka 1997) as well as in the cyanobacterium, Synechocystis (Masamoto et al. 2004). Moreover, genetic manipulation of the carotenoid synthesis suggested that PSII assembly requires the presence of a carotenoid with at least one $\beta$-ionylidene ring, which may play a structural role in early stages of assembly (Bautista et al. 2005b). On the other hand, it is interesting to note that carotenoidless mutants of purple bacteria with type- 2 RCs have normal photosynthesis. These RCs assemble and function properly, although their stability decrease compared to those of the WT (Ouchane et al. 1997). Therefore, in these phototrophic bacteria carotenoids are not essential for structure and function of type-2 RCs..Since photosynthetic complexes are evolutionarily well conserved among cyanobacteria and higher plants, our results demonstrate the general importance of carotenoids in the assembly of photosynthetic complexes and photoprotection of photosynthetic machinery against changing environmental conditions.

In the carotenoid-less $\Delta c r t H / B$ mutant, amount of the large protein subunits of PSII was strongly suppressed as detected by western blotting (Fig. 16). D1 and D2 core complex protein subunits were present at lower level than those of the WT under LAHG conditions. After the cells were exposed to light, even lower level of D1 and D2 protein subunits was detected indicating photooxidation of those proteins in the absence of carotenoids. CP47 and especially CP43 Chl-binding antenna protein subunits were most affected. This is in agreement with the latest X-ray crystallographic model of PSII structure (Guskov et al. 2009, Guskov et al. 2010) which shows that most of the $\beta$-carotene molecules are located in the vicinity of the transmembrane $\alpha$-helices of CP47 and CP43.

For $\Delta c r t H / B, 2 \mathrm{D}$ gel analyses of protein subunits in combination with their radioactive labeling provided clues for the explanation of why no active PSII complexes were assembled. The results show that dimeric PSII complex is not formed and monomeric PSII complex could only be detected by radioactive labeling (Fig. 17, 19). Its amount significantly decreased after chase experiment together with chloramphenicol treatment, which is a protein synthesis inhibitor, suggesting that monomeric PSII complex could actually be formed, 
however, it was very unstable (Fig 19, chase). RC47 appeared as the most dominant complex, which is an intermediate of PSII complex lacking CP43 that is easily detectable by 2D gel electrophoresis (Fig 17). The increase in the level of RC47 after chase experiments can be a response to the decrease in the level of monomeric PSII form by detachment of CP43. Concomitantly an increase in the level of $\mathrm{RCa}$ was also observed, which is also intermediate PSII lacking both CP47 and CP43. It is known that PsbI and PsbH small protein subunits stabilize CP43 and CP47 in PSII complex, respectively (Komenda et al. 2002, Komenda et al. 2005, Dobakova et al. 2007). They were detected in RC47 by immunoblotting following 2D gel separation (Fig. 19). These findings confirmed that not the absence of these two small protein subunits but the absence of $\beta$-carotene resulted in instability of CP47 and especially CP43 in the PSII complex of $\Delta c r t H / B$ mutant. These results suggest the importance of carotenoids for PSII biogenesis. However, presence of RC47 and RCa in carotenoid-less cells indicated that at least PSII core complex consisting of D1-D2 heterodimer can be formed and the $2 \beta$-carotenes (Guskov et al. 2009) in the vicinity of the D1-D2 heterodimer are not primarily responsible for the PSII core complex assembly (Fig. 28).

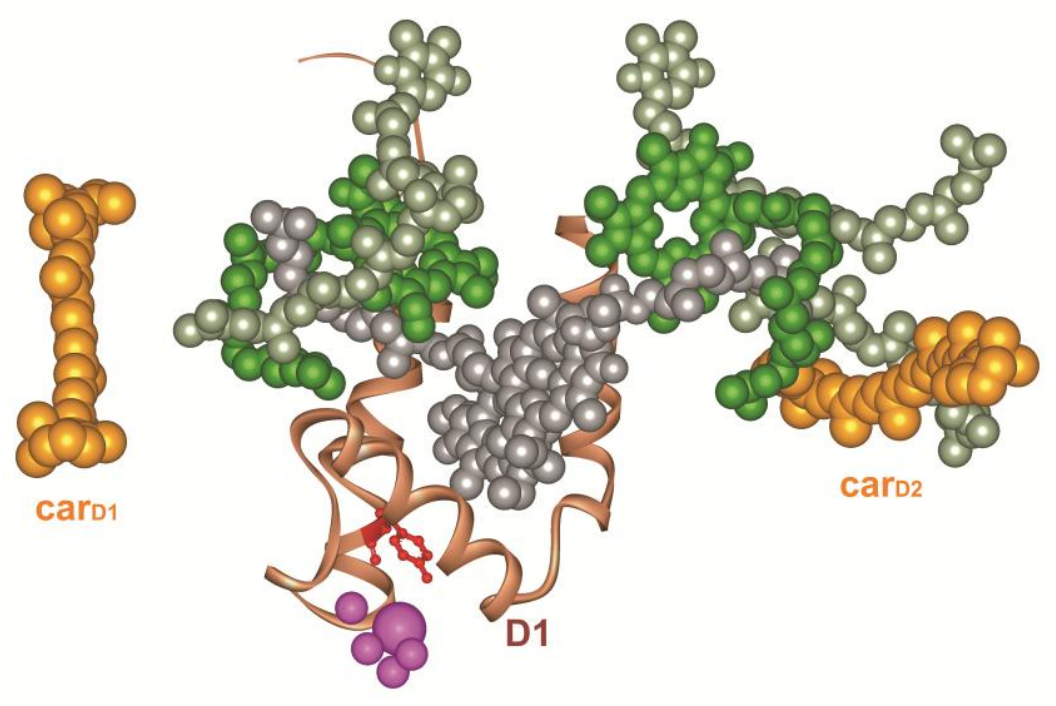

Figure 28: Two $\beta$-carotene molecules located in the PSII core complex.

Two $\beta$-carotene molecules named as car $_{\mathrm{D} 1}$ and car ${ }_{\mathrm{D} 2}$ according to Guskov et al., 2009. The figure was created with the software DSV and by the PDB file 3BZ1 (Guskov et al. 2009).

D1 protein was the most intensively labeled protein in $\mathrm{RC} 47$, as well as in monomeric PSII complex and RCa. An intense radioactive labeling of pulse-chased D1 protein pointed to a rapid functional D1 turnover in the $\Delta c r t H / B$ and it was in line with the selective 
replacement of the D1 protein during PSII repair. However, other newly synthesized PSII proteins such as D2, CP43 and CP47 were detected mainly in the unassembled proteins (U.P.) region and could only transiently be detected by the autoradiogram.

Recent X-ray structural models of cyanobacterial PSII (Ferreira et al. 2004, Loll et al. 2005, Guskov et al. 2009) have demonstrated the presence of $\beta$-carotenes at the interface between initial transmembrane helixes of PSII large protein subunits and small protein subunits outside the heterodimer D1-D2. This applies to D2-Cyt $b_{559}$ pair and to CP47$\mathrm{PsbM} / \mathrm{PsbT}$ pair and especially to CP43-PsbK/PsbZ pair. It has been shown previously that there are two parallel bands of unassembled PSII large protein subunits on the BN PAGE which are slower and faster electrophoretic mobility protein bands (Dobakova et al. 2007, Komenda et al. 2008). The mobility differences between the bands rise from the absence/presence of PSII small protein subunits.. Additional PSII small protein subunits seem to stabilize the PSII large protein subunits in the complex (Komenda et al. 2005, Dobakova et al. 2007, Komenda et al. 2008). In $\Delta c r t H / B$, bands were found in faster electrophoretic mobility of radioactively labeled unassembled CP47, CP43 and D2 large protein subunits. These findings indicate that carotenoid deficiency negatively affected the stability of binding small protein subunits to large protein subunits in PSII (Fig. 18). Data from Northern blot analyses indicated that the transcription of genes encoding PSII large protein subunits is not affected by elimination of carotenoids under LAHG conditions (Fig. 20).

The elimination of carotenoids suppressed the synthesis of PSII proteins in LAHG conditions and the synthesis of the overall membrane proteins during light treatment. This pointed to a general detrimental effect of the absence of carotenoids on the protein subunits. The regulation mechanism behind this suppression has not been elucidated yet. However, it has been shown that oxidative stress related to the action of ROS inhibits the elongation step of D1 translation via oxidation of the elongation factor G (Kojima et al. 2007). We assume that there may be a similar reason for inhibited translation in the $\Delta c r t H / B$ mutant, since lack of carotenoids severely decreased the ability of cells to scavenge ROS and to prevent the inactivation of translation factors.

Cyt $b_{6} f$ complexes possess specific carotenoid-binding sites, suggesting an important structural role for these pigment molecules (Wenk et al. 2005). Despite this expectation, $\Delta c r t H / B$ cells showed a growth rate similar to that of the WT under LAHG conditions and 2D protein analysis revealed similar accumulation of monomeric Cyt $b_{6} f$ complex in both WT and $\Delta c r t H / B$ cells (Fig. 17). This finding indicates that carotenoids are not essential for the assembly of functional Cyt $b_{6} f$ complexes. 
PSI complex can be assembled in the absence of carotenoids.. Interestingly, PSI in the $\Delta c r t H / B$ was mostly present in the monomeric form while the prevailing form in WT cells is the trimeric form. Blue native gel experiments revealed that the trimer/monomer ratio of PSI drastically decreased in the mutant. On the other hand, we cannot exclude that trimeric form exist in the mutant cells and they are destabilized and decomposed during gel analysis. We suggest that carotenoids have an important stabilization function in PSI trimerization domain. This is in accordance with the fact that trimerization domain is rich in $\beta$-carotene (Fig. 29) (Grotjohann and Fromme 2005).

The striking difference between the antenna system in PSI and PSII is the lack of the central antenna domain in PSII. Whereas the PSI central antenna domain contains $96 \mathrm{Chl} a$ and 22 carotenoid molecules carrying the electron transport chain in PSI RC. In contrast, the PSII RC contains only the D1-D2 heterodimer, $2 \beta$-carotene and $6 \mathrm{Chl} a$ molecules (Fig. 28 and Fig. 30). The absence of the central antenna domain in PSII may be the response to its ability for water splitting as an unlimited electron source, which leads to the process of D1 turnover. This process may have hindered the fusion of the RC domain and the antenna domain in PSII,(Fig. 30). Definitely, among photosynthetic membrane complexes in $\Delta c r t H / B$ mutant, PSII was the most severely affected complex by the absence of carotenoids. Indeed, PSII-dependent oxygen-evolving activity of carotenoid-less $\Delta c r t H / B$ cells measured by using an artificial electron acceptor 1,4-parabenzoquinone was undetectable indicating the absence of functional PSII complexes. Additionally, the absence of variable Chl $a$ fluorescence and the absence of transient reduction in P700 kinetics confirmed that in $\Delta c r t H / B$ cells, no active PSII centers are present (Fig 21A, 23). 

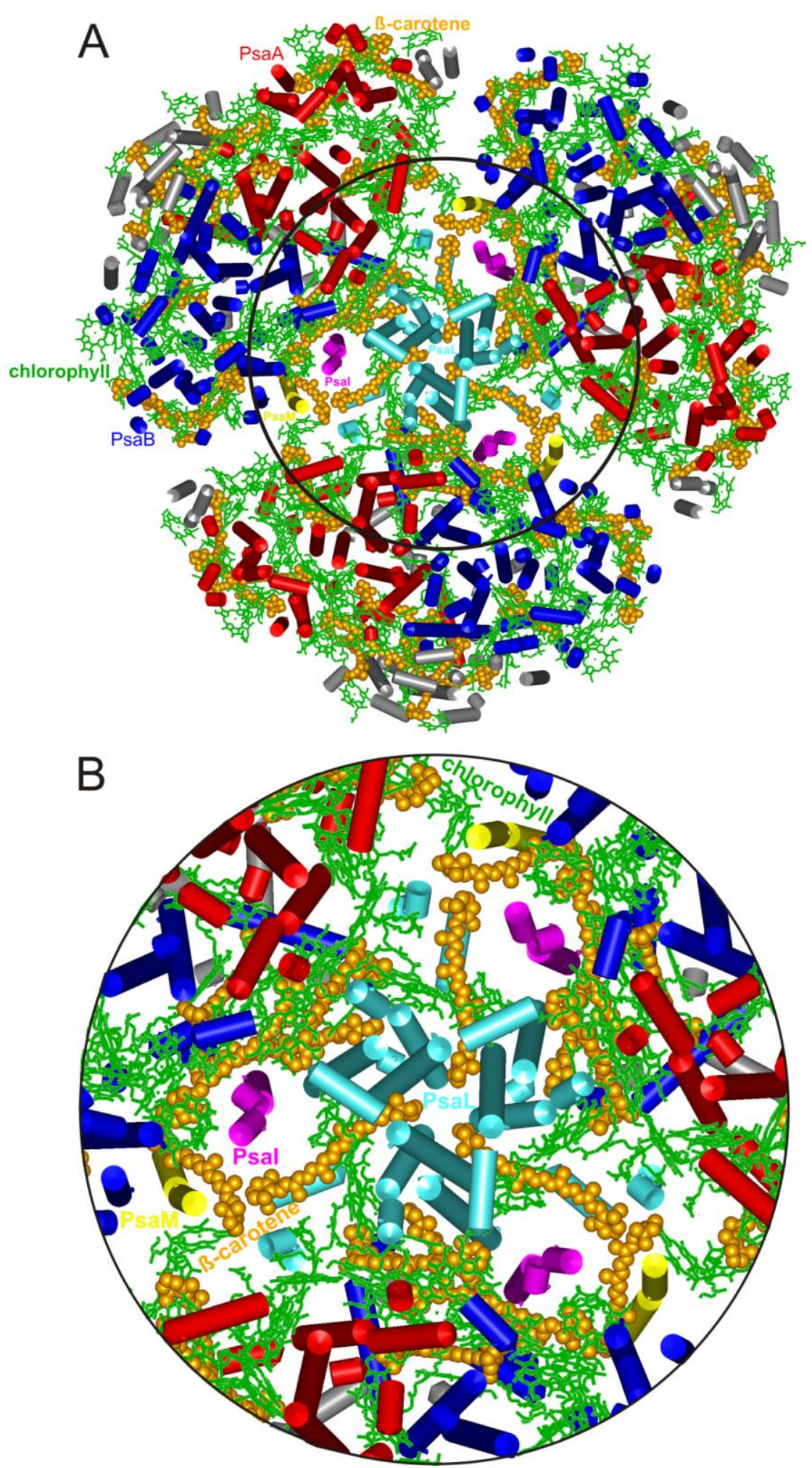

Figure 29: Luminal side view of trimeric PSI complex

(A) Trimerization domain, rich in $\beta$-carotene, shown in black circle and (B) in magnified view. Yellow, carotenoid, green, chlorophyll, light blue, PsaL; violet, PsaI and yellow PsaM. The figure was created with the software DSV and the PDB file 1JB0 (Jordan et al. 2001). 
PSII is known to experience radiation damages even at very low illumination intensities. The main ROS produced in the PSII RC is the very reactive singlet oxygen. This is due to the generation of singlet oxygen during charge recombination between $\mathrm{P}^{2} 80^{+} / \mathrm{Pheo}^{-}$ and to the fact that carotenoid molecules in PSII RC are located too far from P680 to be able to efficiently quench the triplet state Chl (Telfer 2002) (Fig. 28). On the other hand, if the carotenoids were closer, they would probably be immediately oxidized by $\mathrm{P} 60^{+}$because of its strong oxidizing potential (Telfer 2002). For this reason PSII RC is poorly protected from the action of singlet oxygen and an efficient mechanism of PSII repair has evolved in order to maintain the photochemical capacity. When light is in excess, the D1 protein is rapidly degraded and resynthesized to reestablish a fully active PSII RC (Baena-Gonzalez and Aro 2002). A similar mechanism is not known for PSI. After radiation damages its recovery requires several days (Kudoh and Sonoike 2002). Furthermore, the repair from photoinhibition does not require the turnover of a single polypeptide, as in the case of D1, but involves degradation and resynthesis of the whole PSI complex. Although the mechanisms and localization are different, the D1 protein might also be considered as a safety fuse: in fact, once D1 is degraded, not only charge separation but also singlet oxygen production are stopped thus protecting the remaining PSII core complex from oxidation damage and photobleaching (Bergantino et al. 2003). Thus, it appears that in both complexes some sacrificial proteins exist functioning like a safety fuse for the rest of the structure. In the case of PSI large antenna Chl-protein domain while in the case of PSII is the D1 protein of the RC to play this role. It is worth mentioning that $\mathrm{P} 700^{+}$is not such a strong oxidizer as $\mathrm{P}^{\circ} 80^{+}$, and no massive charge recombination has been reported in PSI. This is probably one major reason explaining why different photoprotection strategies evolved in PSI and PSII. It is interesting to point out that, despite the differences, in both cases the antenna systems are fundamental in photoprotection. Even under high light conditions, large antenna system works very efficiently as the excited triplet state Chl $a$ cannot be detected in intact PSI (Grotjohann and Fromme 2005). In addition, PSI photoprotection is mainly mediated by ROS scavenging enzymes (e.g., superoxide dismutase and ascorbate peroxidase) instead of carotenoid scavenging. These enzymes efficiently detoxify reactive species such as hydrogen peroxide $\left(\mathrm{H}_{2} \mathrm{O}_{2}\right)$, superoxide $\left(\mathrm{O}_{2}{ }^{-}\right)$, hydroxyl radicals $(\mathrm{OH})$ produced at the reducing side of PSI (Asada 1999). Therefore, PSI is generally believed to be less sensitive to light stress and its carotenoid related photoprotection mechanisms were less investigated. Norflurazon (inhibitor of phytoene synthase)-treated Scenedesmus obliquus cells lacking carotenoids still contain some PSI and charge separation can be detected (Romer et al. 1995). Samples in which all 
carotenoids are extracted with organic solvents lack quinones but are still able to perform electron transfer from P700 to A0 (Ikegami and Katoh 1991). In carotenoid-less $\Delta c r t H / B$, PSI charge separation and cyclic electron transport could be efficiently performed in LAHG conditions (Fig.21B). However, level of active PSI centers significantly decreased after cells were exposed to low light illumination. Earlier studies suggested that PSI starts to become activated only when as a consequence of unassembled subunits of PSII chlorophyll liberation and degradation (Trebst A and Depka B. 1997). To understand the reason of PSI photoinhibition in carotenoid-less and PSII-less $\Delta c r t H / B$, we used PSII-less mutant strain which contains carotenoids (psbDI, psbDII and psbC genes encoding D2 and CP43 proteins, respectively were blocked) as a control. Nevertheless, PSII-less mutant showed a significant PSI activity similar to WT even if the cells were grown in constant light (Fig. 22). These results suggested that not the inefficient linear electron transport between PSII and PSI but the carotenoid deficiency was the reason of the photoinhibition of PSI.
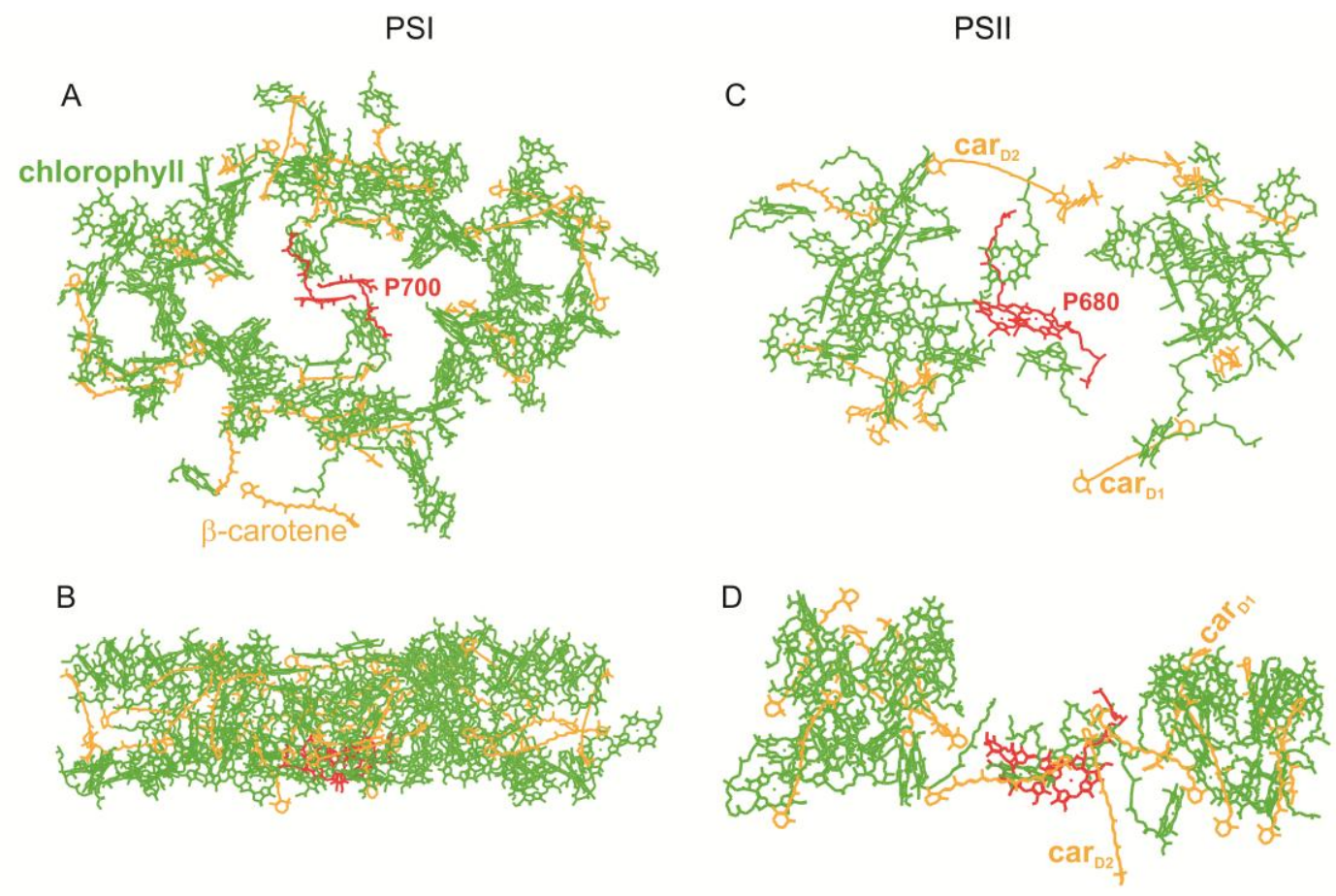

Figure 30: Arrangement of antenna pigments in the PSI and PSII complexes of $T$. elongatus.

Lumenal side view $(A, C)$, side view along the membrane plane (B, D). Green, chlorophyll; orange, $\beta$-carotene; green, $\mathrm{Chl} a$, red, P700 and P680 centers. $\operatorname{car}_{\mathrm{D} 1}$ and car $_{\mathrm{D} 2} ; \beta$-carotene molecules in PSII RC named by Guskov 2009. The figure was created with the software DSV and the PDB files 3BZ1 (Guskov et al. 2009) and 1JB0 (Jordan et al. 2001). 


\subsection{Phosphatidylglycerol (PG) depletion induces an increase in myxoxanthophyll and echinenone biosynthetic activities in Synechocystis PCC 6803 cells}

Investigation of pigment-lipid interaction in a membrane environment is important to understand the primary mechanism of antioxidant activity and bioavailability of carotenoids. Our study has demonstrated the importance of pigment-lipid interactions to drive efficient photosynthesis. Phosphatidylglycerol (PG) is the only phospholipid found in photosynthetic reaction centers. PG depletion resulted in a remarkable suppression of photosynthetic oxygen-evolving activity and impaired PSII activity by probably generation of ROS as shown earlier for pgsA (Hagio et al. 2000) and PALcdsA (Laczkó-Dobos et al. 2008) mutants. Here we studied how carotenoids respond to stress conditions induced by PG depletion in the PGdeficient mutant of Synechocystis, pgsA.

In Synechocystis, carotenoids are synthesized via a branched pathway initiating from common precursors (Fig 6). Lycopene is a central molecule that is present in the synthetic pathway of all carotenoids and their intermediates. Our results suggest PG depletion significantly increased the synthesis of two major carotenoids, myxoxanthophyll and echinenone and on the other hand, the suppression of $\beta$-carotene and zeaxanthin synthesis was observed. This differential effect of PG starvation could be explained by differences between the metabolic pathways leading to the biosynthesis of the different carotenoids (Lagarde et al. 2000). Synthesis towards myxoxanthophyll and a group of $\beta$-carotenes, echinenone and zeaxanthin, is branched at $\gamma$-carotene (Fig. 31). The second branching point is at $\beta$-carotene, where the synthesis of echinenone and that of zeaxanthin diverge (Fig 30). Our results suggest that these steps are regulated differently. The increase in the relative content of echinenone can be explained by its higher stability compared with those of other carotenoid species in Synechocystis (Steiger et al. 1999), whereas its absolute increase in the cytoplasmic membrane can be due to enhanced biosynthesis. However, the higher amount of myxoxanthophyll, a less stable carotenoid species comparing to zeaxanthin and echinenone, seems to indicate enhanced biosynthesis of this compound. 


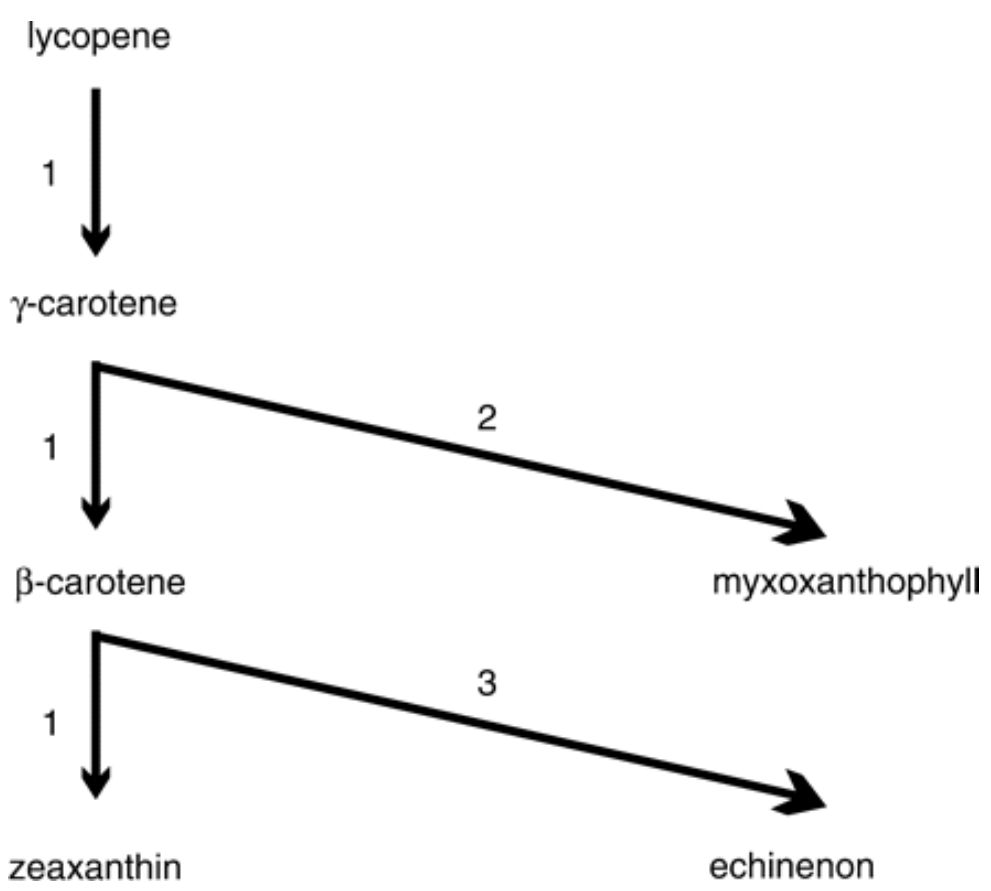

Figure 31: Flow sheet of carotenoid biosynthesis in Synechocystis.

Arrow 1 indicates non-regulated or down-regulated catalytic processes, and arrows 2, 3 indicate up-regulated catalytic processes in carotenoid biosynthesis.

The two up-regulated carotenes, myxoxanthophyll and echinenone, are special protective agents. In Synechocystis, myxoxanthophyll, which was preferentially synthesized, under high light stress provided the strongest protection and echinenone was the most stable carotenoid under photo-oxidative conditions (Steiger et al. 1999). Investigations on the photoprotective function of myxoxanthophyll in cyanobacterium Plectonema boryanum cells under UV radiation stress revealed a reduced efficiency of energy transfer to PSII RCs and an elevated level of myxoxanthophyll (Ivanov et al. 2000). Low temperature stress increased the myxoxanthophyll content of Cylindrospermopsis raciborskii cells (Várkonyi et al. 2002). Myxoxanthophyll is also required for the formation of normal cell wall structure and it stabilizes thylakoid membranes (Mohamed et al. 2005). Induction of myxoxanthophyll biosynthesis by high light exposure in Synechocystis has been demonstrated by Mohamed and Vermaas (2004). However, very little is known about the biological function of both myxoxanthophyll and echinenone.

Increased myxoxanthophyll and echinenone content of the PG-depleted cells was detected in the membranes; nevertheless, a significant amount of carotenoids was also found in the cytosol. The accumulation of carotenoids was demonstrated in the upper nonmembrane layer of the sucrose gradient (Fig. 24). Accordingly, we found increased 
myxoxanthophyll and echinenone contents in the cytosol of PG-depleted cells. Since carotenoids are not water-soluble molecules, they should be bound to proteins in the cytosol. In cyanobacteria, orange carotenoid-binding proteins were found to maintain the carotenoids in the aqueous phase (Kerfeld 2004). Carotenoids occur in all parts of the cyanobacterial cell. Earlier studies suggested that carotenoid-binding proteins were present in cytoplasmic membranes (Bullerjahn and Sherman 1986). Carotenoids were also localized to outer membranes (Jurgens and Weckesser 1985). The carotenoids in the outer membrane were found to be oriented (Jurgens and Mantele 1991).

The increased amount of myxoxanthophyll pointed to its protection role against slowdown of photosynthetic processes generated by PG depletion. High amounts of echinenone and myxoxanthophyll, whose synthesis were up-regulated by PG depletion (Fig. 31 , arrow 2 and 3), seem to protect the structure and function of the photosynthetic apparatus of cyanobacterial cells. On the other hand, the synthesis of $\beta$-carotene and zeaxanthin was non-regulated or down-regulated in the PG-depleted cells (Fig. 31, arrow 1). Synthesis towards myxoxanthophyll and a group of $\beta$-carotene, echinenone and zeaxanthin, is branched at $\gamma$-carotene. The second branching point is at $\beta$-carotene, where the synthesis of echinenone and that of zeaxanthin diverge. These findings suggested that these steps are regulated differently by PG-depleted stress conditions. 


\subsection{CONCLUSIONS}

I. We have successfully generated a viable carotenoid-less mutant in an oxygenic prokaryotic species, Synechocystis. $\Delta c r t H / B$ cells were extremely light sensitive and could grow only under LAHG conditions, demonstrating the protective role of carotenoids against light stress.

Carotenoid-less mutant of Synechocystis, $\Delta c r t H / B$, allowed us study the structural and functional consequences of the complete carotenoid deficiency on photosynthesis here for the first time, in vivo.

i. The structural consequences of the carotenoid deficiency on the assembly of photosynthetic complexes were studied in $\Delta c r t H / B$ :

- Dimeric and monomeric PSII complex could not be formed. Instead, intermediate PSII complexes lacking CP43 and lacking CP43/CP47 were found.

- D1 was the most intensively labeled protein in $\Delta c r t H / B$ indicating D1 turnover was active.

- Small protein subunits binding to the unassembled PSII large protein subunits were not stable without carotenoids.

- PSI and Cyt $b_{6} f$ complexes could be assembled, however trimeric/monomeric form of PSI ratio significantly decreased.

ii. The functional consequences of the carotenoid deficiency on the activity of photosynthetic reaction centers.were studied in $\Delta c r t H / B$ cells:

- There were no active PSII centers.

- PSI centers were active. however they could not maintain their activity in the absence of carotenoids even under low light.

II. Phosphatidylglycerol (PG) depletion leads to a significant increase in the level of both echinenone and myxoxanthophyll suggesting their protection functions under stress conditions. Here we show that the increase of carotenoid content is a response to different stress conditions, not only to high light stress, however, the level of specific carotenoids induced by stress conditions against oxidative damage regulated differently. 


\section{ACKNOWLEDGEMENT}

I am thankful to my supervisors, Dr. Zoltán Gombos \& Dr. Mihály Kis, whose encouragement, guidance and support from the initial to the final level enabled me to develop an understanding of the subject.

I warmly thank to members of the Lipid Function and Structure Group, BRC, for the valuable support and friendly environment during my $\mathrm{PhD}$ studies.

During this work I have collaborated with Dr. Josef Komenda, Dr. László Kovács and Dr. Przemyslaw Malec those I have great regard for.

My sincere thanks are to Dr. Tibor Janda and Dr. Szilvia Tóth for their detailed review, constructive criticism and excellent advice.

I owe my loving thanks to my husband E. Serkan Sozer. Without his encouragement and understanding it would not have been easy for me to finish this work.

Özge Sözer 


\section{REFERENCES}

Allen, M.M. (1968) Simple conditions for growth of unicellular blue-green algae on plates. $J$. Phycol. 4: 1-4.

Amunts, A. and Nelson, N. (2009) Plant photosystem I design in the light of evolution. Structure 17: 637-650.

Anderson, S.L. and McIntosh, L. (1991) Light-activated heterotrophic growth of the cyanobacterium Synechocystis sp. strain PCC 6803: a blue-light-requiring process. J. Bacteriol. 173: 2761-2767.

Asada, K. (1999) The water-water cycle in chloroplasts: Scavenging of active oxygens and dissipation of excess photons. Annual Review of Plant Physiology and Plant Molecular Biology 50: 601-639.

Ausubel, F., Brent, R., Kingston, R.E., Moore, D.D., Seidman, J.G., Smith, J.A. (1995) Short protocols in molecular biology. -John Wiley, New York.

Baena-Gonzalez, E. and Aro, E.M. (2002) Biogenesis, assembly and turnover of photosystem II units. Philosophical Transactions of the Royal Society of London Series BBiological Sciences 357: 1451-1459.

Baniulis, D., Yamashita, E., Whitelegge, J.P., Zatsman, A.I., Hendrich, M.P., Hasan, S.S. (2009) Structure-function, stability, and chemical modification of the cyanobacterial cytochrome $b(6) f$ complex from Nostoc sp PCC 7120. J. Biol. Chem. 284: 9861-9869.

Bautista, J.A., Rappaport, F., Guergova-Kuras, M., Cohen, R.O., Golbeck, J.H., Wang, J.Y. et al. (2005a) Biochemical and biophysical characterization of photosystem I from phytoene desaturase and $\zeta$-carotene desaturase deletion mutants of Synechocystis sp. PCC 6803. J. Biol. Chem. 280: 20030-20041.

Bautista, J.A., Tracewell, C.A., Schlodder, E., Cunningham, F.X., Brudvig, G.W., and Diner, B.A. (2005b) Construction and characterization of genetically modified Synechocystis sp. PCC 6803 Photosystem II core complexes containing carotenoids with shorter $\pi$ conjugation than $\beta$-carotene. J. Biol. Chem. 280: 38839-38850.

Bergantino, E., Segalla, A., Brunetta, A., Teardo, E., Rigoni, F., Giacometti, G.M. et al. (2003) Light- and pH-dependent structural changes in the PsbS subunit of photosystem II. Proc. Natl. Acad. Sci. U. S. A. 100: 15265-15270.

Berglund, A.H., Nilsson, R., and Liljenberg, C. (1999) Permeability of large unilamellar digalactosyldiacylglycerol vesicles for protons and glucose - influence of $\alpha$-tocopherol, $\beta$ carotene, zeaxanthin and cholesterol. Plant Physiology and Biochemistry 37: 179-186.

Bittersmann, E. and Vermaas, W. (1991) Fluorescence lifetime studies of cyanobacterial photosystem II mutants. Biochim. Biophys. Acta. 1098: 105-116.

Bogos, B., Ughy, B., Domonkos, I., Laczko-Dobos, H., Komenda, J., Abasova, L. et al. (2010) Phosphatidylglycerol depletion affects photosystem II activity in Synechococcus sp PCC 7942 cells. Photosynth. Res. 103: 19-30. 
Breitenbach, J., Fernandez-Gonzalez, B., Vioque, A., and Sandmann, G. (1998) A higher-plant type $\zeta$-carotene desaturase in the cyanobacterium Synechocystis PCC6803. Plant Mol. Biol. 36: 725-732.

Britton G, Liaaen-Jensen S and Pfander H. (2004) Carotenoids Handbook. Birkhauser Verlag, Basel-Boston-Berlin

Britton, G. (1995a) Structure and properties of carotenoids in relation to function. FASEB J. 9: 1551-1558.

Britton, G. (1995b) UV/visible spectroscopy. In Carotenoids: spectroscopy. Edited by Britton, G., Liaaen-Jensen, S., and Pfander, H. pp . 13-63. Birkhauser Verlag, Basel.

Bryant D.A..(1994) The Molecular Biology of Cyanobacteria. Kluwer Academic Publishers, Dordrecht, The Netherlands

Bullerjahn, G.S. and Sherman, L.A. (1986) Identification of a carotenoid-binding protein in the cytoplasmic membrane from the heterotrophic cyanobacterium Synechocystis $s p$ strain PCC6714. J. Bacteriol. 167: 396-399.

Cogdell, R.J. and Frank, H.A. (1987) How carotenoids function in photosynthetic bacteria. Biochim. Biophys. Acta 895: 63-79.

Cramer, W.A., Zhang, H.M., Yan, J.S., Kurisu, G., and Smith, J.L. (2006)

Transmembrane traffic in the cytochrome $b(6) f$ complex. Annual Review of Biochemistry 75: 769-790.

Dobakova, M., Tichy, M., and Komenda, J. (2007) Role of the PsbI protein in photosystem II assembly and repair in the cyanobacterium Synechocystis sp. PCC 6803. Plant Physiol. 145: 1681-1691.

Domonkos, I., Malec, P., Laczko-Dobos, H., Sozer, O., Klodawska, K., Wada, H. et al. (2009) Phosphatidylglycerol depletion induces an increase in myxoxanthophyll biosynthetic activity in Synechocystis PCC6803 cells. Plant Cell Physiol. 50: 374-382.

Domonkos, I., Malec, P., Sallai, A., Kovacs, L., Itoh, K., Shen, G.Z. et al. (2004) Phosphatidylglycerol is essential for oligomerization of photosystem I reaction center. Plant Physiol. 134: 1471-1478.

El-Mohsnawy, E., Kopczak, M.J., Schlodder, E., Nowaczyk, M., Meyer, H.E., Warscheid, B. et al. (2010) Structure and function of intact photosystem I monomers from the cyanobacterium Thermosynechococcus elongatus. Biochemistry 49: 4740-4751.

Enami, I., Okumura, A., Nagao, R., Suzuki, T., Iwai, M., and Shen, J.R. (2008) Structures and functions of the extrinsic proteins of photosystem II from different species. Photosynth. Res. 98: 349-363.

Farmilo, A. and Wilkinson, F. (1973) On the mechanism of quenching of singlet oxygen in solution. Photochem. Photobiol. 18: 447-450. 
Fernandez Gonzalez, B., Sandmann, G., and Vioque, A. (1997) A new type of asymmetrically acting $\beta$-carotene ketolase is required for the synthesis of echinenone in the cyanobacterium Synechocystis sp. PCC 6803. J. Biol. Chem. 272: 9728-9733.

Ferreira, K.N., Iverson, T.M., Maghlaoui, K., Barber, J., and Iwata, S. (2004)

Architecture of the photosynthetic oxygen-evolving center. Science 303: 1831-1838.

Formaggio, E., Cinque, G., and Bassi, R. (2001) Functional architecture of the major lightharvesting complex from higher plants. J Mol Biol 314: 1157-1166.

Frank, H.A. and Cogdell, R.J. (1996) Carotenoids in photosynthesis. Photochem. Photobiol. 63: 257-264.

Fromme, P., Jordan, P., and Krauss, N. (2001) Structure of photosystem I. Biochim. Biophys. Acta. 1507: 5-31.

Funk, C. and Vermaas, W. (1999) A cyanobacterial gene family coding for single-helix proteins resembling part of the light-harvesting proteins from higher plants. Biochemistry 38: 9397-9404.

Gombos, Z., Varkonyi, Z., Hagio, M., Iwaki, M., Kovacs, L., Masamoto, K. et al. (2002) Phosphatidylglycerol requirement for the function of electron acceptor plastoquinone $Q(B)$ in the photosystem II reaction center. Biochemistry 41: 3796-3802.

Goodwin, T.W. (1980) Carotenoids in green and purple photosynthetic bacteria. Journal of Scientific \& Industrial Research 39: 682-688.

Gotz, T., Windhovel, U., Boger, P., and Sandmann, G. (1999) Protection of photosynthesis against ultraviolet-B radiation by carotenoids in transformants of the cyanobacterium Synechococcus PCC7942. Plant Physiol 120: 599-604.

Grotjohann, I. and Fromme, P. (2005) Structure of cyanobacterial Photosystem I. Photosynth. Res. 85: 51-72.

Gruszecki, W.I. and Strzalka, K. (2005) Carotenoids as modulators of lipid membrane physical properties. Biochim Biophys Acta 1740: 108-115.

Guskov, A., Gabdulkhakov, A., Broser, M., Glockner, C., Hellmich, J., Kern, J. et al. (2010) Recent progress in the crystallographic studies of photosystem II. Chemphyschem 11: $1160-1171$.

Guskov, A., Kern, J., Gabdulkhakov, A., Broser, M., Zouni, A., and Saenger, W. (2009) Cyanobacterial photosystem II at 2.9-Å resolution and the role of quinones, lipids, channels and chloride. Nat. Struct. Mol. Biol. 16: 334-342.

Hagio, M., Gombos, Z., Varkonyi, Z., Masamoto, K., Sato, N., Tsuzuki, M. et al. (2000) Direct evidence for requirement of phosphatidylglycerol in photosystem II of photosynthesis. Plant Physiol. 124: 795-804.

Hartwig, A. (2001) Zinc finger proteins as potential targets for toxic metal ions: differential effects on structure and function. Antioxid. Redox. Signal. 3: 625-634. 
Havaux, M., Tardy, F., Ravenel, J., Chanu, D., and Parot, P. (1996) Thylakoid membrane stability to heat stress studied by flash spectroscopic measurements of the electrochromic shift in intact potato leaves: influence of the xanthophyll content. Plant, Cell Environ. 19: 1359-1368.

He, Q., Dolganov, N., Bjorkman, O., and Grossman, A.R. (2001) The high light-inducible polypeptides in Synechocystis PCC6803. Expression and function in high light. J. Biol. Chem. 276: 306-314.

Horton, P., Ruban, A.V., and Walters, R.G. (1996) Regulation of light harvesting in green plants. Annu. Rev. Plant Physiol Plant Mol. Biol. 47: 655-684.

Ikegami, I. and Katoh, S. (1991) Antenna chlorophyll-a has a structural role in stabilizing the functional conformation of P-700 Chlorophyll-Protein Complexes. Biochim. Biophys. Acta. 1059: 275-280.

Ikeuchi, M., Eggers, B., Shen, G.Z., Webber, A., Yu, J.J., Hirano, A. et al. (1991) Cloning of the $p s b K$ gene from Synechocystis sp. PCC 6803 and characterization of photosystem II in mutants lacking PSII-K. J. Biol. Chem. 266: 11111-11115.

Ivanov, A.G., Miskiewicz, E., Clarke, A.K., Greenberg, B.M., and Huner, N.P. (2000) Protection of photosystem II against UV-A and UV-B radiation in the cyanobacterium Plectonema boryanum: the role of growth temperature and growth irradiance. Photochem Photobiol 72: 772-779.

Ivleva, N.B., Shestakov, S.V., and Pakrasi, H.B. (2000) The carboxyl-terminal extension of the precursor D1 protein of photosystem II is required for optimal photosynthetic performance of the cyanobacterium Synechocystis sp PCC 6803. Plant Physiol. 124: 14031411.

Jordan, P., Fromme, P., Witt, H.T., Klukas, O., Saenger, W., and Krauss, N. (2001) Three-dimensional structure of cyanobacterial photosystem I at $2.5 \AA$ resolution. Nature 411: 909-917.

Jurgens, U.J. and Mantele, W. (1991) Orientation of carotenoids in the outer-membrane of Synechocystis PCC 6714 (Cyanobacteria). Biochim. Biophys. Acta. 1067: 208-212.

Jurgens, U.J. and Weckesser, J. (1985) Carotenoid-containing outer-membrane of Synechocystis sp strain PCC6714. J. Bacteriol. 164: 384-389.

Kandori, H., Sasabe, H., and Mimuro, M. (1994) Direct determination of a lifetime of the S2 state of $\beta$-carotene by femtosecond time-resolved fluorescence spectroscopy. Journal of the American Chemical Society 116: 2671-2672.

Kerfeld, C.A. (2004) Structure and function of the water-soluble carotenoid-binding proteins of cyanobacteria. Photosynth. Res. 81: 215-225.

Kilian, O., Steunou, A.S., Fazeli, F., Bailey, S., Bhaya, D., and Grossman, A.R. (2007) Responses of a thermophilic Synechococcus isolate from the microbial mat of octopus spring to light. Appl. Environ. Microbiol. 73: 4268-4278. 
Kis, M., Zsiros, O., Farkas, T., Wada, H., Nagy, F., and Gombos, Z. (1998) Light-induced expression of fatty acid desaturase genes. Proc. Natl. Acad. Sci. U. S. A 95: 4209-4214.

Knox, J.P. and Dodge, A.D. (1985) Singlet oxygen and plants. Phytochemistry 24: 889-896.

Kojima, K., Oshita, M., Nanjo, Y., Kasai, K., Tozawa, Y., Hayashi, H. et al. (2007) Oxidation of elongation factor $\mathrm{G}$ inhibits the synthesis of the D1 protein of photosystem II. Mol. Microbiol. 65: 936-947.

Komenda, J., Lupinkova, L., and Kopecky, J. (2002) Absence of the psbH gene product destabilizes photosystem II complex and bicarbonate binding on its acceptor side in Synechocystis PCC 6803. Eur. J. Biochem. 269: 610-619.

Komenda, J., Reisinger, V., Muller, B.C., Dobakova, M., Granvogl, B., and Eichacker, L.A. (2004) Accumulation of the D2 protein is a key regulatory step for assembly of the photosystem II reaction center complex in Synechocystis PCC 6803. J. Biol. Chem. 279: 48620-48629.

Komenda, J., Tichy, M., and Eichacker, L.A. (2005) The PsbH protein is associated with the inner antenna CP47 and facilitates D1 processing and incorporation into PSII in the cyanobacterium Synechocystis PCC 6803. Plant Cell Physiol. 46: 1477-1483.

Komenda, J., Kuvikova, S., Granvogl, B., Eichacker, L.A., Diner, B.A., and Nixon, P.J. (2007) Cleavage after residue Ala352 in the C-terminal extension is an early step in the maturation of the D1 subunit of photosystem II in Synechocystis PCC 6803. Biochimica et Biophysica Acta-Bioenergetics 1767: 829-837.

Komenda, J., Nickelsen, J., Tichy, M., Prasil, O., Eichacker, L.A., and Nixon, P.J. (2008) The cyanobacterial homologue of HCF136/YCF48 is a component of an early photosystem II assembly complex and is important for both the efficient assembly and repair of photosystem II in Synechocystis sp. PCC 6803. J. Biol. Chem. 283: 22390-22399.

Kudoh, H. and Sonoike, K. (2002) Irreversible damage to photosystem I by chilling in the light: cause of the degradation of chlorophyll after returning to normal growth temperature. Planta 215: 541-548.

Kurisu, G., Zhang, H., Smith, J.L., and Cramer, W.A. (2003) Structure of the cytochrome $b 6 f$ complex of oxygenic photosynthesis: tuning the cavity. Science 302: 1009-1014.

Kuvikova, S., Tichy, M., and Komenda, J. (2005) A role of the C-terminal extension of the photosystem II D1 protein in sensitivity of the cyanobacterium Synechocystis PCC 6803 to photoinhibition. Photochem. Photobiol. Sci. 4: 1044-1048.

Laczkó-Dobos, H., Ughy, B., Tóth, S.Z., Komenda, J., Zsiros, O., Domonkos, I. (2008) Role of phosphatidylglycerol in the function and assembly of Photosystem II reaction center, studied in a $c d s A$-inactivated PAL mutant strain of Synechocystis sp. PCC6803 that lacks phycobilisomes. Biochim. Biophys. Acta 1777: 1184-1194.

Lagarde, D. and Vermaas, W. (1999) The zeaxanthin biosynthesis enzyme $\beta$-carotene hydroxylase is involved in myxoxanthophyll synthesis in Synechocystis sp PCC 6803. FEBS Lett. 454: 247-251. 
Lagarde, D., Beuf, L., and Vermaas, M. (2000) Increased production of zeaxanthin and other pigments by application of genetic engineering techniques to Synechocystis sp strain PCC 6803. Appl. Environ. Microbiol. 66: 64-72.

Lichtenthaler, H.K. (1987) Chlorophylls and carotenoids: pigments of photosynthetic biomembranes. Methods Enzymol. 148: 350-382.

Liu, L.N., Chen, X.L., Zhang, Y.Z., and Zhou, B.C. (2005) Characterization, structure and function of linker polypeptides in phycobilisomes of cyanobacteria and red algae: An overview. Biochimica et Biophysica Acta-Bioenergetics 1708: 133-142.

Loll, B., Kern, J., Saenger, W., Zouni, A., and Biesiadka, J. (2005) Towards complete cofactor arrangement in the 3.0 A resolution structure of photosystem II. Nature 438: 10401044.

Lupinkova, L. and Komenda, J. (2004) Oxidative modifications of the Photosystem II D1 protein by reactive oxygen species: From isolated protein to cyanobacterial cells. Photochem. Photobiol. 79: 152-162.

MacColl, R. and Guard-Friar, D. (1987) Phycobiliproteins. CRC Press, Boca Raton, FL

Macpherson, A.N., Arellano, J.B., Fraser, N.J., Cogdell, R.J., and Gillbro, T. (2001) Efficient energy transfer from the carotenoid S-2 state in a photosynthetic light-harvesting complex. Biophysical Journal 80: 923-930.

Mantoura, R.F.C. and Llewellyn, C.A. (1983) The rapid-determination of algal chlorophyll and carotenoid pigments and their breakdown products in natural waters by reverse-phase High-Performance Liquid Chromatography. Anal. Chim. Acta 151: 297-314.

Martinez-Ferez, I., FernandezGonzalez, B., Sandmann, G., and Vioque, A. (1994) Cloning and expression in Escherichia coli of the gene coding for phytoene synthase from the cyanobacterium Synechocystis sp. PCC6803. Biochim. Biophys. Acta. 1218: 145-152.

Martinez-Ferez, I.M. and Vioque, A. (1992) Nucleotide sequence of the phytoene desaturase gene from Synechocystis sp. PCC 6803 and characterization of a new mutation which confers resistance to the herbicide norflurazon. Plant Mol. Biol. 18: 981-983.

Masamoto, K. and Furukawa, K. (1997) Accumulation of zeaxanthin in cells of the cyanobacterium, Synechococcus sp. strain PCC 7942 grown under high irradiance. J. Plant Physiol. 151: 257-261.

Masamoto, K., Misawa, N., Kaneko, T., Kikuno, R., and Toh, H. (1998) $\beta$-carotene hydroxylase gene from the cyanobacterium Synechocystis sp. PCC6803. Plant Cell Physiol. 39: 560-564.

Masamoto, K., Zsiros, O., and Gombos, Z. (1999) Accumulation of zeaxanthin in cytoplasmic membranes of the cyanobacterium Synechococcus sp. strain PCC7942 grown under high light condition. J. Plant Physiol. 155: 136-138.

Masamoto, K., Wada, H., Kaneko, T., and Takaichi, S. (2001) Identification of a gene required for cis-to-trans carotene isomerization in carotenogenesis of the cyanobacterium Synechocystis sp. PCC 6803. Plant Cell Physiol. 42: 1398-1402. 
Masamoto, K., Hisatomi, S., Sakurai, I., Gombos, Z., and Wada, H. (2004) Requirement of carotene isomerization for the assembly of photosystem II in Synechocystis sp. PCC 6803. Plant Cell Physiol. 45: 1325-1329.

Maxwell, P.C. and Biggins, J. (1977) Kinetic behavior of P-700 during induction of photosynthesis in algae. Biochim. Biophys. Acta. 459: 442-450.

Mayer, M.P. (1995) A new set of useful cloning and expression vectors derived from pBlueScript. Gene 163: 41-46.

Mohamed, A. and Jansson, C. (1989) Influence of light on accumulation of photosynthesisspecific transcripts in the cyanobacterium Synechocystis 6803. Plant Mol. Biol. 13: 693-700.

Mohamed, H.E. and Vermaas, W. (2004) Slr1293 in Synechocystis sp strain PCC 6803 is the C-3 ',4 ' desaturase (CrtD) involved in myxoxanthophyll biosynthesis. J. Bacteriol. 186: $5621-5628$.

Mohamed, H.E., van de Meene, A.M.L., Roberson, R.W., and Vermaas, W.F.J. (2005) Myxoxanthophyll is required for normal cell wall structure and thylakoid organization in the cyanobacterium, Synechocystis sp strain PCC 6803. J. Bacteriol. 187: 6883-6892.

Molnar, P. and Szabolcs, J. (1993) (Z/E)-Photoisomerization of C40-Carotenoids by Iodine. Journal of the Chemical Society-Perkin Transactions 2261-266.

Moon, B.Y., Higashi, S.I., Gombos, Z., and Murata, N. (1995) Unsaturation of the membrane lipids of chloroplasts stabilizes the photosynthetic machinery against lowtemperature photoinhibition in transgenic tobacco plants. Proc. Natl. Acad. Sci. U. S. A. 92: 6219-6223.

Muh, F., Renger, T., and Zouni, A. (2008) Crystal structure of cyanobacterial photosystem II at $3.0 \AA$ resolution: A closer look at the antenna system and the small membrane-intrinsic subunits. Plant Physiology and Biochemistry 46: 238-264.

Mullineaux, C.W. (2008) Phycobilisome-reaction centre interaction in cyanobacteria. Photosynth. Res. 95: 175-182.

Murata, N., Sato, N., Takahashi, N., and Hamazaki, Y. (1982) Compositions and positional distributions of fatty acids in phospholipids from leaves of chilling-sensitive and chilling-resistant plants. Plant Cell Physiol. 23: 1071-1079.

Murata, N. (1983) Molecular species composition of phosphatidylglycerols from chillingsensitive and chilling-resistant plants. Plant Cell Physiol. 24: 81-86.

Murata, N. and Omata, T. (1988) Isolation of cyanobacterial plasma membranes. Methods Enzymol. 167: 245-251.

Nakamura, Y., Miyajima, N., Hirosawa, M., Kaneko, T., Tabata, S. (1996) Cyanobase: The Genome Database for Synechocystis sp. strain PCC 6803 in Proc. Seventh Workshop on Genome Informatics; 214-215. 
Nixon, P.J., Michoux, F., Yu, J.F., Boehm, M., and Komenda, J. (2010) Recent advances in understanding the assembly and repair of photosystem II. Annals of Botany 106: 1-16.

Nowaczyk, M.M., Hebeler, R., Schlodder, E., Meyer, H.E., Warscheid, B., and Rogner, M. (2006) Psb27, a cyanobacterial lipoprotein, is involved in the repair cycle of photosystem II. Plant Cell 18: 3121-3131.

Ouchane, S., Picaud, M., Vernotte, C., and Astier, C. (1997) Photooxidative stress stimulates illegitimate recombination and mutability in carotenoid-less mutants of Rubrivivax gelatinosus. EMBO J. 16: 4777-4787.

Palsson, L.O., Flemming, C., Gobets, B., van Grondelle, R., Dekker, J.P., and Schlodder, E. (1998) Energy transfer and charge separation in photosystem I: P700 oxidation upon selective excitation of the long-wavelength antenna chlorophylls of Synechococcus elongatus. Biophysical Journal 74: 2611-2622.

Polivka, T. and Sundstrom, V. (2004) Ultrafast dynamics of carotenoid excited states from solution to natural and artificial systems. Chemical Reviews 104: 2021-2071.

Promnares, K., Komenda, J., Bumba, L., Nebesarova, J., Vacha, F., and Tichy, M. (2006) Cyanobacterial small chlorophyll-binding protein ScpD (HliB) is located on the periphery of photosystem II in the vicinity of PsbH and CP47 subunits. J. Biol. Chem. 281: 32705-32713.

Punginelli, C., Wilson, A., Routaboul, J.M., and Kirilovsky, D. (2009) Influence of zeaxanthin and echinenone binding on the activity of the orange carotenoid protein. Biochim Biophys Acta 1787: 280-288.

Rakhimberdieva, M.G., Elanskaya, I.V., Vermaas, W.F.J., and Karapetyan, N.V. (2010) Carotenoid-triggered energy dissipation in phycobilisomes of Synechocystis sp PCC 6803 diverts excitation away from reaction centers of both photosystems. Biochimica et Biophysica Acta-Bioenergetics 1797: 241-249.

Rappaport, F. and Diner, B.A. (2008) Primary photochemistry and energetics leading to the oxidation of the (Mn)4Ca cluster and to the evolution of molecular oxygen in Photosystem II. Coordination Chemistry Reviews 252: 259-272.

Rippka, R., Deruelles, J., Waterbury, J.B., Herdman, M., and Stanier, R.Y. (1979) Generic assignments, strain histories and properties of pure cultures of cyanobacteria. J. Gen. Microbiol. 111: 1-61.

Ritz, T., Damjanovic, A., Schulten, K., Zhang, J.P., and Koyama, Y. (2000) Efficient light harvesting through carotenoids. Photosynth. Res. 66: 125-144.

Romer, S., Senger, H., and Bishop, N.I. (1995) Characterization of the carotenoidless strain of Scenedesmus obliquus, mutant C-6E, a living photosystem I model. Bot. Acta 108: 80-86.

Roose, J.L., Kashino, Y., and Pakrasi, H.B. (2007) The PsbQ protein defines cyanobacterial Photosystem II complexes with highest activity and stability. Proc. Natl. Acad. Sci. U. S. A. 104: 2548-2553. 
Ruengjitchatchawalya, M., Kovacs, L., Mapaisansup, T., Sallai, A., Gombos, Z., Ponglikitmongkol, M. et al. (2005) Higher plant-like fluorescence induction and thermoluminescence characteristics in cyanobacterium, Spirulina mutant defective in $\mathrm{PQH}(2)$ oxidation by cyt $b(6) / f$ complex. J. Plant Physiol. 162: 1123-1132.

Sakurai, I., Hagio, M., Gombos, Z., Tyystjarvi, T., Paakkarinen, V., Aro, E.M. et al. (2003) Requirement of phosphatidylglycerol for maintenance of photosynthetic machinery. Plant Physiol. 133: 1376-1384.

Sas, K.N., Kovacs, L., Zsiros, O., Gombos, Z., Garab, G., Hemmingsen, L. et al. (2006) Fast cadmium inhibition of photosynthesis in cyanobacteria in vivo and in vitro studies using perturbed angular correlation of gamma-rays. Journal of Biological Inorganic Chemistry 11: 725-734.

Satoh, K. and Yamamoto, Y. (2007) The carboxyl-terminal processing of precursor D1 protein of the photosystem II reaction center. Photosynth. Res. 94: 203-215.

Schäfer, L., Vioque, A., and Sandmann, G. (2005) Functional in situ evaluation of photosynthesis-protecting carotenoids in mutants of the cyanobacterium Synechocystis PCC6803. J. Photochem. Photobiol. B-Biol. 78: 195-201.

Schagger, H. and von Jagow, G. (1987) Tricine-sodium dodecyl sulfate-polyacrylamide gel electrophoresis for the separation of proteins in the range from 1 to $100 \mathrm{kDa}$. Anal. Biochem. 166: 368-379.

Schagger, H., Cramer, W.A., and von Jagow, G. (1994) Analysis of molecular masses and oligomeric states of protein complexes by blue native electrophoresis and isolation of membrane-protein complexes by 2-dimensional native electrophoresis. Anal. Biochem. 217: 220-230.

Schodel, R., Irrgang, K.D., Voigt, J., and Renger, G. (1999) Quenching of chlorophyll fluorescence by triplets in solubilized light-harvesting complex II (LHCII). Biophysical Journal 76: 2238-2248.

Sobotka, R., Duerhring, U., Komenda, J., Peter, E., Gardian, Z., Tichy, M. (2008) Importance of the cyanobacterial GUN4 protein for chlorophyll metabolism and assembly of photosynthetic complexes. J. Biol. Chem. 283: 25794-25802.

Steiger, S., Schafer, L., and Sandmann, G. (1999) High-light-dependent upregulation of carotenoids and their antioxidative properties in the cyanobacterium Synechocystis PCC 6803. J. Photochem. Photobiol. B-Biol. 52: 14-18.

Takaichi, S., Maoka, T., and Masamoto, K. (2001) Myxoxanthophyll in Synechocystis sp. PCC 6803 is myxol 2'-dimethyl-fucoside, (3R,2'S)-myxol 2'-(2,4-di-O-methyl-alpha-Lfucoside), not rhamnoside. Plant Cell Physiol 42: 756-762.

Takaichi, S. and Mochimaru, M. (2007) Carotenoids and carotenogenesis in cyanobacteria: unique ketocarotenoids and carotenoid glycosides. Cell Mol Life Sci 64: 2607-2619.

Telfer, A. (2002) What is $\beta$-carotene doing in the photosystem II reaction centre? Philos Trans R Soc Lond B Biol Sci 357: 1431-1439. 
Towbin, H., Staehelin, T., and Gordon, J. (1979) Electrophoretic transfer of proteins from polyacrylamide gels to nitrocellulose sheets: procedure and some applications. Proc. Natl. Acad. Sci. U. S. A 76: 4350-4354.

Trebst, A. and Depka, B. (1997) Role of carotene in the rapid turnover and assembly of photosystem II in Chlamydomonas reinhardtii. FEBS Lett 400: 359-362.

Van Amerongen, H. and Van Grondelle, R. (2001) Understanding the energy transfer function of LHCII, the major light-harvesting complex of green plants. Journal of Physical Chemistry B 105: 604-617.

Varkonyi, Z., Masamoto, K., Debreczeny, M., Zsiros, O., Ughy, B., Gombos, Z. et al. (2002) Low-temperature-induced accumulation of xanthophylls and its structural consequences in the photosynthetic membranes of the cyanobacterium Cylindrospermopsis raciborskii: An FTIR spectroscopic study. Proc. Natl. Acad. Sci. U. S. A. 99: 2410-2415.

Vass, I., Styring, S., Hundal, T., Koivuniemi, A., Aro, E.M., and Andersson, B. (1992) Reversible and irreversible intermediates during photoinhibition of photosystem 2. Stable reduced Qa species promote chlorophyll triplet formation. Proc. Natl. Acad. Sci. U. S. A. 89: $1408-1412$.

Welburn, A.R. and Lichtenthaler, H. (1984) Formula and program to determine total carotenoids and Chl $a$ and $b$ of leaf extracts in different solvents. In Advances in Photosynthesis Research. Edited by Sybesma, C. pp . 9-12. Martinus Nijhoff/Dr. W. Junk Publishers, The Hague.

Wenk, S.O., Schneider, D., Boronowsky, U., Jager, C., Klughammer, C., de Weerd, F.L. et al. (2005) Functional implications of pigments bound to a cyanobacterial cytochrome $b(6) f$ complex. FEBS J. 272: 582-592.

Widomska, J., Kostecka-Gugala, A., Latowski, D., Gruszecki, W.I., and Strzalka, K. (2009) Calorimetric studies of the effect of cis-carotenoids on the thermotropic phase behavior of phosphatidylcholine bilayers. Biophysical Chemistry 140: 108-114.

Wilson, A., Ajlani, G., Verbavatz, J.M., Vass, I., Kerfeld, C.A., and Kirilovsky, D. (2006) A soluble carotenoid protein involved in phycobilisome-related energy dissipation in cyanobacteria. Plant Cell 18: 992-1007.

Wilson, A., Kinney, J.N., Zwart, P.H., Punginelli, C., D'Haene, S., Perreau, F. (2010) Structural determinants underlying photoprotection in the photoactive Orange Carotenoid Protein of cyanobacteria. J. Biol. Chem. 285: 18364-18375.

Woodall, A.A., Britton, G., and Jackson, M.J. (1997a) Carotenoids and protection of phospholipids in solution or in liposomes against oxidation by peroxyl radicals: relationship between carotenoid structure and protective ability. Biochim Biophys Acta 1336: 575-586.

Woodall, A.A., Lee, S.W., Weesie, R.J., Jackson, M.J., and Britton, G. (1997b) Oxidation of carotenoids by free radicals: relationship between structure and reactivity. Biochim Biophys Acta 1336: 33-42. 


\section{ÖSSZEFOGLALÓ}

\section{Karotinoidok részvétele a cianobaktériumok fotoszintetikus komplexeinek összeszerelődésében és müködésében}

A fotoszintézis alapvető biofizikai és biokémiai folyamat, amelynek során a napfény energiája az élethez nélkülözhetetlen kémiai energiává alakul át. A cianobaktériumok a legősibb ismert oxigéntermelő, fotoszintetizáló, prokarióta szervezetek, melyek az endoszimbiózis elmélete szerint a növényi kloroplasztisz ösének tekinthetök. A cianobaktériumok még napjainkban is Földünk éves oxigéntermelésének közel 30\%-át biztosítják.

A cianobaktériumok igen ellenálló, a környezeti változásokhoz jól alkalmazkodó szervezetek, melyek hatékonyan védekeznek a reaktív oxigéngyökök (ROS) fotoszintetikus aktivitást csökkentő, fotoinhibíciót eredményező fotooxidatív károsító hatásai ellen is. A karotinoidok müködése nélkülözhetetlen a védekezéshez. A fénykárosodástól azáltal védik a sejtet, hogy képesek kioltani a gerjesztett szinglet és triplet állapotú klorofillt, valamint befogni a szinglet oxigént, amely rendkívül káros hatású ROS (Knox és Dodge 1985). Nélkülözhetetlen védőszerepük mellett a karotinoidok járulékos fénybegyüjtő pigmentként is működnek (Frank és Cogdell 1996) és részt vesznek a membránok felépítésében is (Cogdell és Frank1987, Gruszecki és Strzalka 2005).

A crtB gén által kódolt fitoén-szintáz enzim katalizálja a karotinoidok bioszintézisének első lépését, a fitoén kialakítását. A fitoénből további enzimek közremüködésével különböző karotin- és xantofillmolekulák képződnek.

Az egyik legintenzívebben tanulmányozott cianobaktérium, a Synechocystis sp. PCC 6803 jellemző karotinoidjai a következők: $\beta$-karotin, hidroxiszármazéka a zeaxantin, ketoszármazékai az echinenon és a 3'-hidroxiechinenon, valamint a mixoxantofill, amely egy karotinoid glikozid (Britton és mtsai 2004, Takaichi és Mochimaru 2007). Az újabb röntgenkrisztallográfiás analízisek feltárták, hogy a cianobakteriális fotoszintetikus komplexekben a $\beta$-karotin az egyetlen karotinoidfajta, de az összes többi karotinoid is megtalálható a cianobaktériumok tilakoidmembránjában, a citoplazmamembránban és a citoszolban. Különböző stresszkörülmények hatására mennyiségük megnő a sejtben. A $\beta$ karotin-molekulán levő szubsztituensek kémiai természete meghatározza a molekula antioxidatív tulajdonságát, szerepét a fénykárosodás elleni védelemben (Britton 1995a). A hidroxi-karotinoidok általában jók a peroxidgyökök inaktiválásában (Woodall és mtsai 
1997b), míg a ketoszármazékok hatékonyabbak a reaktív szinglet oxigén kioltásában (Woodall és mtsai 1997a), és legstabilabbnak bizonyultak a peroxidgyökök és a fotooxidáció károsításával szemben (Steiger és mtsa 1999).

Röntgenkrisztallográfiás analízissel (Guskov és mtsai 2009) 12 karotinoidot azonosítottak Thermosynechococcus elongatus PSII komplexében monomerenként. A PSII a fotooxidatív stresszel szemben a leginkább érzékeny fotoszintetikus komplex. Korábbi tanulmányok arra engednek következtetni, hogy a $\beta$-karotin elengedhetetlenül szükséges a D1 fehérje felhalmozódásához Chlamydomonas reinhardtii zöld algában (Trebst és Depka 1997) és Synechocystis PCC 6803 cianobaktériumban is (Masamoto és mtsai 2004). Tehát a karotinoidok jelenléte fontos a müködőképes PSII felépüléséhez.

A T. elongatus PSI komplexek szerkezetében 22 karotinoidmolekulát azonosítottak monomerenként (Jordan és mtsai 2001, Fromme és mtsai 2001, Grotjohann és Fromme 2005). A PSI általában kevésbé érzékeny a fénystresszre, és a karotinoidok részvétele a fénykárosodás elleni védelemben a PSI esetén kevéssé ismert. A fitoén-szintáz gátló norflurazonnal történt kezelés hatására karotinoidmentessé vált Chlamydomonas reinhardtii sejtek még tartalmaztak PSI komplexeket, melyekben töltésszeparációt is megfigyeltek (Romer és mtsai 1995). A tilakoidmembránokból szerves oldószerrel kivonták a karotinoidokat és a kinonokat, ezután is még megtörtént az elektronszállítás a P700 és az A0 között (Ikegami és Katoh 1991).

A fotoszintézis folyamatai a PSI- és PSII-reakciócentrumokban játszódnak le, melyek a tilakoidmembránba ágyazott pigment-fehérje komplexek. A lipid-fehérje és lipid-pigment kölcsönhatások fontos szerepet játszanak a fotoszintézis szabályozásában. A cianobaktériumok tilakoidmembránja jellegzetes lipidösszetételü, mely glikolipideket és egy foszfolipidet tartalmaz. A cianobaktériumokban és a magasabbrendü növények tilakoidmembránjában egyetlen foszfolipid fordul elö, a foszfatidil-glicerin (PG). A T. elongatus fotoszintetikus komplexeinek röntgenkrisztallográfiás szerkezetvizsgálata PGmolekulákat mutatott ki a PSII komplex CP43 és D1 fehérjéi között (Guskov és mtsai 2009), valamint a PSI szerkezetében is (Jordan és mtsai 2001). A PG eltávolítása a sejtekből a klorofilltartalom csökkenését és a fotoszintetikus folyamatok lassulását okozta. A $Q_{A}$ és $Q_{B}$ közti elektrontranszport gátlása volt megfigyelhető, ami a $\mathrm{Q}_{\mathrm{A}}$ túlredukálódásához és $\mathrm{Q}_{\mathrm{A}}{ }^{-2}$ képződéséhez vezet (Gombos és mtsai 2002, Laczko-Dobos és mtsai 2008). A PG esszenciális az alacsony hőmérsékleti stressz (Murata és mtsai 1982, Murata 1983, Moon és mtsai 1995) és a fénystressz elleni védekezésben (Vass és mtsai 1992). 
A globális környezet változása egyre gyakrabban idéz elő olyan stresszkörülményeket, melyek a fotoszintetizáló szervezetekre hatva csökkentik a fotoszintézis hatékonyságát. A stresszkörülmények között a fotoszintézisben müködő védekező mechanimusok megismerésének igénye a különböző körülmények között eltérő fejlődési sajátosságokkal rendelkező növények, algák és cianobaktériumok kutatásához vezetett. A cianobaktériumok a növényi kloroplasztisz ösének tekinthetők, így kiváló modellszervezetek a magasabbrendü növények fotoszintézisének tanulmányozásához. Az antioxidáns tulajdonságokkal bíró karotinoidok fontos szerepet játszanak a stresszkörülmények elleni harcban, de a védekezésben elengedhetetlen szerkezeti és funkcionális sajátosságaik csak részben felderítettek. Ezért munkám során a következő célokat tűztem ki:

I. Felderíteni, hogy in vivo, a fotoszintetikus apparátusban a karotinoidok hiánya milyen (i) szerkezeti változásokat okoz, és ez milyen (ii) funkcionális következményekkel jár. Ennek érdekében az első olyan oxigéntermelö, fotoszintetikus prokarióta (Synechocystis sp. PCC 6803 cianobaktérium) mutánst létrehozni, melyben a karotinoidok szintézise teljes mértékben gátolt.

II. Ezenkívül a karotinoidok védő szerepét tanulmányozni olyan stresszkörülmények között, melyet a PG hiánya váltott ki a Synechocystis sp. PCC 6803 pgsA mutánsban.

A fitoén-szintáz enzimet kódoló $\operatorname{crtB}$ gént inaktiváltuk a részlegesen karotinoidhiányos $\Delta c r t H$ mutánsban. Így létrejött egy teljes mértékben karotinoidmentes kettős mutáns, a $\Delta c r t H / B$, amely csak sötétben, glükóztartalmú tápoldatban volt fenntartható. HPLC analízissel igazoltuk, hogy a $\Delta c r t H / B$ sejtek semmilyen karotinoidszármazékot nem tartalmaznak. A $\Delta c r t H / B$ sejtkultúra kékes színe arra utalt, hogy a sejtekben a fikobilinek a domináns pigmentek. A karotinoidok hiánya nem érintette szignifikánsan a fikobiliproteinek szintézisét és felhalmozódását, a klorofill szintézisét és akkumulációját viszont gátolta. Fénykezelés hatására a mutáns sejtek fokozatosan kifehéredtek, elvesztették pigmentációjukat és elpusztultak, igazolva, hogy a karotinoidok nélkülözhetetlen elemei a fotoprotekciónak.

Western blot analízissel kimutattuk, hogy a karotinoidmentes $\Delta c r t H / B$ mutánsban a PSII nagy fehérjealegységeinek szintje igen alacsony, míg a PSI és a citokróm-b ${ }_{6}$ f fehérjéinek mennyisége nem csökkent. LAHG körülmények között a D1 és D2 fehérjealegységek szintje sokkal alacsonyabb volt, mint a vad típusban. Miután a sejteket megvilágítottuk, a D1 és D2 fehérjék mennyisége tovább csökkent, jelezve a karotinoidok hiányában bekövetkező fotooxidációt. A CDP47 és különösen a CP43 klorofillkötő antennaalegységek szintje volt a 
leginkább érintett. Ez a megfigyelés összhangban van a PSII legutóbbi röntgenkrisztallográfiás szerkezeti modelljével, mely szerint a $\beta$-karotin molekulák többsége a CP47 és CP43 alegységek transzmembrán $\alpha$-hélixeinek közelében helyezkedik el. A $\Delta c r t H / B$ sejtek fehérje alegységeinek 2D-gélanalízise radioaktív ,pulse-chase” jelöléssel kombinálva megadta a kulcsot annak magyarázatához, hogy miért nem épülnek fel aktív PSII komplexek a mutánsban. Az eredmények megmutatták, hogy PSII-dimerek nem képesek kialakulni $\beta$-karotin hiányában, sőt még a nagyon instabil PSII-monomerek is csak radioaktív jelöléssel voltak detektálhatóak. A CP47 és különösen a CP43 alegységek nem kötődtek stabilan a PSII komplexben, ezért csak egy intermedier PSII komplex, az RC47 (melyből a CP43 hiányzik) volt képes felhalmozódni gélelektroforézissel detektálható mennyiségben. A $\Delta c r t H / B$ sejtek tilakoidjában a D1 fehérje volt a radioaktívan leginkább jelölödött fehérje, ami jelzi, hogy a D1 fehérje „steady state turnovere” karotinoidok hiányában is fennmaradt. A radioaktívan jelölődött D1 fehérje leginkább az RC47 komplexben volt detektálható, valamint a monomer PSII-ben és az RCa-ban, amely egy olyan intermedier PSII komplex, ahonnan a CP43 és a CP47 is hiányzik. Miután a „chase” kísérletet kloramfenikolkezeléssel, azaz a fehérjeszintézis gátlásával kombináltuk, a PSII-monomerek eltűntek a gélből, ami a komplex instabilitására és fényérzékenységére utal. Sőt $\beta$-karotin hiányában azoknak a kis fehérje alegységeknek a kapcsolódása sem stabil, amelyek a nagy PSII-alegységekhez kötődnek a komplexek összeszerelődése során. A PSII komplexszel ellentétben, a PSI és a citokróm- $b_{6} f$ komplexek felépülnek, bár a trimer/monomer PSI aránya szignifikánsan csökkent karotinoidok hiányában.

Kétségtelenül a PSII volt a karotinoidok hiányában leginkább érintett fotoszintetikus membránkomplex a $\Delta c r t H / B$ mutánsban. A karotinoidhiányos mutáns sejtek valóban nem tartalmaztak müködőképes PSII komplexeket, amit a PSII-függő oxigénfejlesztő aktivitás mérésével igazoltunk. Továbbá a PSII klorofill-a fluoreszcencia mérései és a P700 tranziens redukciókinetikájának mérései megerősítették, hogy a $\Delta c r t H / B$ sejtekben nem alakultak ki aktív PSII-reakciócentrumok. Ezzel szemben a PSI-hez köthető töltésszeparáció és ciklikus elektrontranszport müködik a LAHG-körülmények között nevelt $\Delta c r t H / B$ sejtekben is. Azonban, miután a sejteket megvilágítottuk, az aktív PSI-reakciócentrumok mennyisége szignifikánsan csökkent. Azért, hogy megértsük a PSI fotoinhibíciójának okát a karotinoidmentes és aktív PSII-mentes $\Delta c r t H / B$ sejtekben, méréseket végeztünk egy másik PSII-hiányos mutáns törzsben, melyben a D2 és a CP43 alegységek szintézise gátolt. A karotinoidokat is tartalmazó PSII-hiányos mutáns konstans PSI-aktivitást mutatott, még akkor is, ha a sejteket folyamatos fényen neveltük. Az eredmények arra utalnak, hogy nem a 
kevésbé hatékony lineáris elektrontranszport, hanem a karotinoidok hiánya vezetett a PSI fotoinhibíciójához.

A Synechocystis sp. PCC 6803 pgsA sejtekben a foszfatidil-glicerin kiürítése csökkentette a PSII aktivitását, valószínűleg a ROS fokozott termelődése következtében. Ezért megmértük a sejtek karotinoidtartalmának és -összetételének változását a PG kiürítésének ideje alatt. A karotinoidok analízise és a felhalmozódás helyének meghatározása céljából tilakoid- és citoplazmamembrán-frakciókat izoláltunk mind a PG-vel kiegészített tápoldatban nevelt, mind a PG-hiányos sejtekből. A citoplazma- és tilakoidmembránokat lépcsős cukorgradiensen ultracentrifugálással elválasztva szemmel látható volt, hogy a PGhiányos sejtek több karotinoidot tartalmaztak, mint a PG-vel kiegészített tápoldatban nevelt sejtek, különösen a gradiens felső rétegében, ahol a sejtek vízoldékony, membránt nem tartalmazó frakciója gyült össze. HPLC-vel határoztuk meg a pgsA sejtekből és az izolált membránfrakciókból extrahált karotinoidokat. Abszorpciós spektrumuk és retenciós idejük alapján mixoxantofil, zeaxantin, echinenon és $\beta$-karotin karotinoidokat azonosítottunk. A PGvel kiegészített tápoldatban nevelt mintákhoz képest a PG-hiányos mintákban csökkent a $\beta$ karotin és a zeaxantin mennyisége. A mixoxantofil mennyisége kb. háromszorosára nőtt a PG-hiányos mintákban, míg az echinenon mennyisége kétszer nagyobb volt a PG-hiányos tilakoidmembránban és kisebb mértékben nőtt az egész sejtben, mint a PG-vel kiegészített mintákban. Az egyes karotinoidfajták arányát is kiszámítottuk a HPLC-kromatogramokból a csúcsok területe alapján. A mixoxantofil és echinenon karotinoidok aránya magasabb volt a PG-hiányos sejtekben, izolált membránokban és a citoszolban is mint a PG-vel kiegészített mintákban. Ezen eredmények alapján arra következtethetünk, hogy a PG-kiürülés következtében fellépő fotooxidatív károsodás egyes specifikus karotinoidok szintjének növekedését indukálta. Ezt a specifikus növekedést valószínüleg a karotinoidok bioszintézisének a stressz hatására megváltozott regulációja okozta.

Vizsgálataink alapján levonhatjuk azt a következtetést, hogy a karotinoidok nélkülözhetetlen résztvevői a müködőképes fotoszintetikus komplexek felépülésének, különös tekintettel a PSII-re. Karotinoidok hiányában a $\Delta c r t H / B$ sejtek rendkívül fényérzékenyek, még alacsony intenzitású fénykezelés is erős fotoinhibíciót okoz. Másrészt kimutattuk, hogy a karotinoidok védő szerepe nem csak fénystressz esetén, de másfajta stresszkörülmények között is nélkülözhetetlen. A PG-kiürülés okozta fotooxidatív károsodás specifikus karotinoidok mennyiségének a megnövekedését eredményezte nemcsak a fotoszintetikus membránokban, de a citoplazmamembránban és a citoszolban is. 


\section{SUMMARY}

Photosynthesis is a vital process by which the energy of sunlight is converted into chemical energy needed for life. Cyanobacteria are the oldest known oxygenic photosynthetic prokaryotic organisms regarded as ancestors of plant chloroplast according to the endosymbiosis theory. Cyanobacteria contribute up to $30 \%$ of the yearly oxygen production on Earth.

Cyanobacteria are remarkably resistant organisms to changes in environmental conditions and very well protected against photooxidative damage generated by reactive oxygen species (ROS) whose attacks might result in the decline of the photosynthetic activity (photoinhibition). Carotenoids are indispensible components in the protection. Their photoprotective role is related to their ability to quench excited singlet-state and triplet-state chlorophyll, and scavenge the singlet-state oxygen, that are highly destructive ROS (Knox and Dodge 1985). Besides this very essential protective role, carotenoids act as accessory light harvesting pigments (Frank and Cogdell 1996) and regulate the membrane organization (Cogdell and Frank 1987, Gruszecki and Strzalka 2005).

Phytoene synthase encoded by the $\operatorname{crtB}$ gene, which is the first committed step in carotenoid biosynthesis pathway, produces phytoene which is converted to various carotenes and xanthophylls. In Synechocystis sp. PCC 6803, one of the most studied cyanobacteria, the major carotenoids are as follows; $\beta$-carotene; its hydroxyl derivative, zeaxanthin; its keto derivative, echinenone and 3'hydroxyechinenone and the carotenoid glycoside, myxoxanthophyll (Britton et al. 2004, Takaichi and Mochimaru 2007). Recent X-ray structural analysis revealed that $\beta$-carotene is the only carotenoid identified in the photosynthetic complexes of cyanobacteria. Besides $\beta$-carotene, all other carotenoids are found in the thylakoid membrane, cytoplasmic membrane and cytosol in cyanobacteria. The increase in their level is detected under various stress conditions. The substitutions of the $\beta$ carotene molecule determine the antioxidative properties against photooxidative stress (Britton 1995a). In general, hydroxy carotenoids are good in inactivating peroxy radicals (Woodall et al. 1997b) whereas keto derivatives are more efficient in quenching of reactive singlet oxygen (Woodall et al. 1997a) and possess the best stability against peroxy radicals and photooxidation (Steiger et al. 1999).

Twelve carotenoids were found in monomeric PSII complex of Thermosynechococcus elongatus (T. elongatus) by X-ray crystallography (Guskov et al. 2009). PSII is believed to be 
the most sensitive photosynthetic complex to photooxidative stress which is likely due to the absence of central antenna domain in PSII. Earlier studies suggested that $\beta$-carotene is vital for accumulation of D1 in the green alga Chlamydomonas reinhardtii (Trebst and Depka 1997) as well as in Synechocystis PCC 6803 (Masamoto et al. 2004). Therefore, carotenoid availability seems to be a major factor in the assembly of functional PSII.

Twenty two carotenoids have been identified in the structure of monomeric PSI from T. elongatus (Jordan et al. 2001, Fromme et al. 2001, Grotjohann and Fromme 2005). PSI is generally less sensitive to light and its carotenoid-triggered photoprotection is less known. Norflurazon (inhibitor of phytoene synthase)-treated Scenedesmus obliquus cells lacking carotenoids still contain some PSI and charge separation can be detected (Romer et al. 1995). Samples in which all carotenoids are extracted with organic solvents lack the quinones but are still able to perform electron transfer from P700 to A0 (Ikegami and Katoh 1991).

Photosynthetic processes occur in PSI and PSII RC composed of pigment-protein complexes embedded in the thylakoid membrane. Lipid-protein and lipid-pigment interactions play an important role in the regulation of photosynthesis. Thylakoid membranes of cyanobacteria possess a characteristic membrane lipid composition that consists of glycolipids and phospholipids. In cyanobacteria and in the thylakoid membrane of higher plants, phosphatidylglycerol (PG) is the only phospholipid. The recent X-ray crystallographic structure of T. elongatus showed that there are PG molecules in the PSII complex localized between CP43 and D1 (Guskov et al. 2009) as well as in PSI (Jordan et al. 2001). PG depletion results in a decrease of the Chl content of cells and in a general slowdown of photosynthetic processes. A suppression of electron transport from $\mathrm{Q}_{\mathrm{A}}$ to $\mathrm{Q}_{\mathrm{B}}$ was detected, which may lead to over-reduction of $\mathrm{Q}_{\mathrm{A}}$ and to the generation of $\mathrm{Q}_{\mathrm{A}}{ }^{2-}$ (Gombos et al. 2002, Laczkó-Dobos et al. 2008). PG plays an essential against low-temperature stress (Murata et al. 1982, Murata 1983, Moon et al. 1995) and high light stress (Vass et al. 1992).

Changes in global environment might lead to stress conditions in photosynthetic organisms and limit the efficiency of photosynthesis. Understanding photosynthesis and its protective mechanisms might lead to the development of plant, algae and cyanobacteria with improved growth characteristics even under stress conditions. Cyanobacteria, our model organisms, are regarded as an origin of the plant chloroplast; therefore they are excellent to study higher plant photosynthesis. Carotenoids are very important protective agents in photosynthesis due to their anti-oxidative properties against photooxidative damage. Their structural and functional features in protection mechanisms are not completely elucidated yet. Complete genome sequences and the transformability of several cyanobacterial strains allow 
us to generate various mutants and study the importance of carotenoids in photosynthetic processes. Therefore, the aims of my thesis are:

I. Generation of a viable oxygenic photosynthetic prokaryotic mutant in cyanobacterium Synechocystis that is completely deficient in carotenoid synthesis. The aim of creating this mutant is to study (i) the structural and (ii) the functional consequences of carotenoid deficiency on photosynthesis for the first time, in vivo.

II. Studying how carotenoids respond to stress conditions other than light stress; to this end PG depletion was induced in the Synechocystis sp. PCC 6803 pgsA strain.

The $\operatorname{crt} B$ gene encoding phytoene synthase was inactivated in the partially carotenoid-less mutant $\Delta c r t H$. Thus, a carotenoid-less double mutant, $\Delta c r t H / B$, was produced. $\triangle c r t H / B$ cells are extremely light sensitive and only grown in light activated heterotrophic growth LAHG conditions (in the presence of $5-10 \mathrm{mM}$ glucose and in the dark with an exposure of $5 \mu \mathrm{mol}$ photons $\mathrm{m}^{-2} \mathrm{~s}^{-1}$ white light for $10 \mathrm{~min} /$ day). HPLC analysis demonstrated that the $\Delta c r t H / B$ cells contained no carotenoid derivatives. The bluish color of the $\Delta c r t H / B$ cells indicated that phycobiliproteins were the most dominant pigments and their synthesis and accumulation was not significantly suppressed. On the other hand, chlorophyll synthesis and accumulation was suppressed by carotenoid deficiency. The mutant cells gradually bleached and died in the light indicating that carotenoids are indispensible components in photoprotection mechanism against light stress.

In the carotenoid-less $\Delta c r t H / B$ mutant levels of the large protein subunits of PSII were strongly suppressed, however, not those of PSI and Cyt $b_{6} f$ as detected by western blotting. D1 and D2 core-complex protein subunits were present at lower level than those of the WT under LAHG conditions. After the cells were exposed to light, even lower level of D1 and D2 protein subunits could be detected indicating photooxidation of those proteins in the absence of carotenoids. The level of CP47 and especially CP43 Chl-binding antenna protein subunits were the most affected. This is in agreement with the latest X-ray crystallographic model of PSII structure, which shows that most of the $\beta$-carotene molecules are located in the vicinity of the transmembrane $\alpha$-helices of CP47 and CP43. 2D gel analyses of protein subunits of $\Delta c r t H / B$ in combination with their radioactive pulse-chase labeling provided clues how to explain why no active PSII complexes were assembled. The results show that, dimeric PSII complex could not be formed in the absence of $\beta$-carotene, even though very unstable monomeric PSII complex could be detected only by radioactive labeling. CP47 and especially CP43 protein subunits were not stable in the PSII complex. Therefore, only the intermediate PSII complex, RC47 lacking CP43 was able to accumulate 
to the level detectable by gel electrophoresis. The D1 protein subunit was the most labeled protein in $\Delta c r t H / B$ indicating that the steady state D1 turnover was functioning in the carotenoid deficient mutant. D1 labeling could be detected mostly in RC47 as well as in monomeric PSII complex and RCa, intermediate PSII complex lacking both CP43 and CP47 protein subunits. After chase experiment together with chloramphenicol treatment which is a protein synthesis inhibitor, monomeric PSII complex disappeared indicating instability and light susceptibility of the complex. Moreover, small protein subunits binding to the unassembled PSII large protein subunits were not stable without $\beta$-carotene. In contrast to PSII, PSI and Cyt $b_{6} f$ could be assembled, however the ratio of trimeric/monomeric PSI complexes was significantly decreased in the carotenoid deficiency.

Definitely, among photosynthetic membrane complexes in the $\Delta c r t H / B$ mutant, PSII was the most severely affected complex by the absence of carotenoids. Indeed, PSIIdependent oxygen-evolving activity was not detected in the carotenoid-less $\Delta c r t H / B$ cells under all conditions demonstrating the absence of functional PSII complexes. Moreover, measurements of PSII Chl $a$ fluorescence and transient reduction kinetics of P700 confirmed that in $\Delta c r t H / B$ cells no active PSII centers are formed. In contrast, PSI charge separation and cyclic electron transport could be efficiently performed in $\Delta c r t H / B$ cells grown under LAHG conditions. However, changes in the level of active PSI centers significantly decreased after cells were exposed to low light illumination. To understand the reason of PSI photoinhibition in carotenoid-less and active PSII-less $\Delta c r t H / B$, we made use of PSII-less mutant strain (psbDI, psbDII and psbC genes encoding D2 and CP43 proteins, respectively were blocked). Nevertheless, PSII-less mutants, containing carotenoids showed a constant PSI activity even if the cells were grown in the constant light. These results suggested that not the inefficient linear electron transport between PSII and PSI but the carotenoid deficiency was the reason for the photoinhibition of PSI.

Phosphatidylglycerol (PG) depletion suppressed the PSII activity in Synechocystis PCC6803 pgsA mutant cells most likely caused by elevated ROS production. Therefore, the changes in carotenoid content and composition during longer-term PG depletion were measured. In order to analyze and localize the carotenoid accumulation in PG-deficient mutant we isolated thylakoid and cytoplasmic membrane fractions either from PGsupplemented or from PG-depleted cells. The separation of cytoplasmic and thylakoid membrane layers by ultracentrifugation on a stepwise sucrose density gradient revealed that the PG-depleted cells (-PG14day and -PG21day) contained higher amount of carotenoids 
than the PG-supplemented (+PG) cells, especially in the upper part of the gradient, which contained a water-soluble non-membrane fraction of the cells. We analyzed the carotenoid species extracted from $\mathrm{pgsA}_{s}$ cells and from isolated membrane fractions by HPLC. In pgsA cells, myxoxanthophyll, zeaxanthin, echinenone and $\beta$-carotene were identified on the basis of their absorption spectra and their retention times. The amounts of $\beta$-carotene and zeaxanthin decreased in the PG-depleted samples compared to those of the PG-supplemented samples. The amount of myxoxanthophyll increased approximately 3-fold in all PG-depleted samples, and the amount of echinenone was twice as high in the PG-depleted thylakoid membranes and to a lesser extent in whole cells than in PG-supplemented cells. Relative amount of the individual carotenoid species was also estimated from their peak areas from the HPLC chromatograms. The proportion of myxoxanthophyll and echinenone in the carotenoids of PG-depleted whole cells, isolated membranes and cytosol proved to be higher than in the corresponding PG-supplemented controls. These results suggested that photooxidative damage mediated by PG depletion induced the level of specific carotenoids. This is most likely the result of differently regulated biosynthetic steps of carotenoids under stress conditions.

We can conclude that carotenoids are indispensable components for the assembly and the function of photosynthetic complexes especially that of PSII shown for the first time, in vivo. In the absence of carotenoids cells were extremely light sensitive and exposure to the low light resulted in strong photoinhibition. On the other hand we demonstrate that carotenoid accumulation is a response to different stress conditions other than high light stress as well, however, the increase in the level of specific carotenoids induced by stress conditons are regulated differently. 


\section{PUBLICATIONS}

\section{Source of the publication of the thesis}

Domonkos I, Malec P, Laczkó-Dobos H, Sozer O, Klodawska K, Wada H, Strzalka K, Gombos Z. Phosphatidylglycerol depletion induces an increase in myxoxanthophyll biosynthetic activity in Synechocystis PCC6803 cells Plant Cell Physiol. 2009; 50(2):374-82

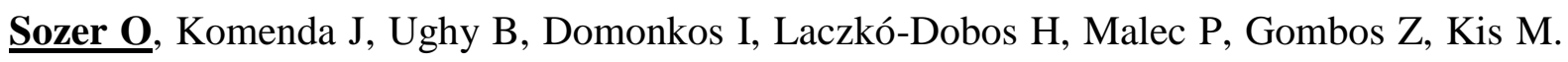
Involvement of carotenoids in the synthesis and assembly of protein subunits of photosynthetic reaction centers of Synechocystis sp. PCC 6803 Plant Cell Physiol. 2010; 51(5):823-35

\section{$\underline{\text { Sozer O, }}$ Kovács L, Kis M, Gombos Z}

Involvement of carotenoids in the activity of photosynthetic reaction centers of Synechocystis sp. PCC 6803 (In preparation)

\section{Other publications}

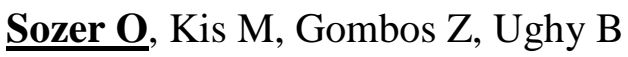

Proteins, glycerolipids and carotenoids in the functional photosystem II architecture Frontiers in Bioscience 2011; 16: 619-643

Laczkó-Dobos H, Todinova S.J, Sozer O, Komenda J, Kis M, Sallai A, Dobrikova A.G, Ughy B, Debreczeny M, Gombos Z, Apostolova E.L, Domonkos I. Identification of thylakoid membrane thermal transitions in Synechocystis sp. PCC6803 photosynthetic mutants (accepted) 